\title{
Hydrogen Production via Hydrolysis and Alcoholysis of Light Metal-Based Materials: A Review
}

Cite as

Nano-Micro Lett.

(2021) 13:134

Liuzhang Ouyang ${ }^{1,2} \bowtie$, Jun Jiang ${ }^{1}$, Kang Chen ${ }^{1}$, Min Zhu ${ }^{1,2}$, Zongwen $\mathrm{Liu}^{3,4} \bowtie$

Received: 27 February 2021

Accepted: 13 April 2021

Published online: 5 June 2021

(C) The Author(s) 2021

\section{HIGHLIGHTS}

- An overview of the recent advances in hydrogen production from light metal-based materials is presented, including hydrolysis of Mg-based alloys and hydrides, hydrolysis of Al-based alloys and hydrides and (catalyzed) hydrolysis/alcoholysis of borohydrides.

- Hydrogen production and storage in a close loop are achieved via hydrolysis and regeneration of borohydrides, demonstrating a promising step toward the large-scale application of chemical hydrogen storage materials in a fuel cell-based hydrogen economy.

ABSTRACT As an environmentally friendly and high-density energy carrier, hydrogen has been recognized as one of the ideal alternatives for fossil fuels. One of the major challenges faced by "hydrogen economy" is the development of efficient, low-cost, safe and selective hydrogen generation from chemical storage materials. In this review, we summarize the recent advances in hydrogen production via hydrolysis and alcoholysis of lightmetal-based materials, such as borohydrides, Mg-based and Al-based materials, and the highly efficient regeneration of borohydrides. Unfortunately, most of these hydrolysable materials are still plagued by sluggish kinetics and low hydrogen yield. While a number of strategies including catalysis, alloying, solution modification, and ball milling have been developed to overcome these drawbacks, the high costs required for the "one-pass" utilization of hydrolysis/alcoholysis systems have ultimately made these techniques almost impossible for practical large-scale applications. Therefore, it is imperative to develop low-cost material systems based on abundant resources and effective recycling technologies of spent fuels for efficient

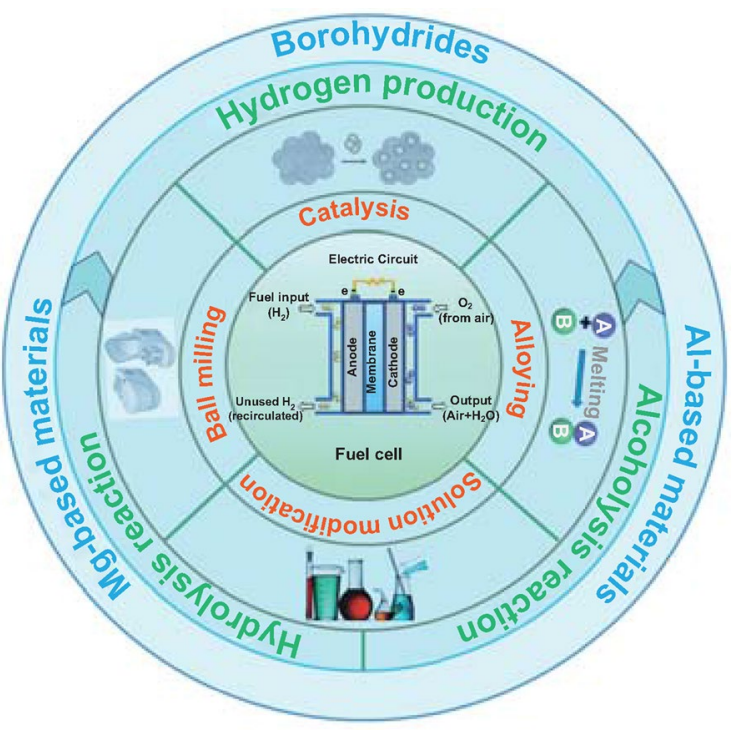
transport, production and storage of hydrogen in a fuel cell-based hydrogen economy.

KEYWORDS Hydrolysis; Alcoholysis; Light metal-based materials; Borohydrides; Magnesium; Aluminum; Hydrogen production

$\triangle$ Liuzhang Ouyang, meouyang@scut.edu.cn; Zongwen Liu, zongwen.liu@sydney.edu.au

1 School of Materials Science and Engineering, Guangdong Provincial Key Laboratory of Advanced Energy Storage Materials, South China University of Technology, Guangzhou 510641, People's Republic of China

2 China-Australia Joint Laboratory for Energy and Environmental Materials, Key Laboratory of Fuel Cell Technology of Guangdong Province, Guangzhou 510641, People's Republic of China

3 School of Chemical and Biomolecular Engineering, The University of Sydney, Sydney, NSW 2006, Australia

4 The University of Sydney Nano Institute, The University of Sydney, Sydney, NSW 2006, Australia 


\section{Introduction}

Hydrogen, the most abundant content in the universe, has a number of advantages over conventional fuels. It has a high energy density (142 $\left.\mathrm{MJ} \mathrm{kg}^{-1}\right)$ and is environmentally friendly. As such, hydrogen energy economy was proposed by Hofman et al. [1] in the early 70s. Encouragingly, the emerging of proton exchange membrane fuel cells (PEMFCs) in the mid-2000s made large-scale hydrogen applications achievable in vehicles or portable electronic devices [2-4]. Particularly, a commercially available car driven by $4 \mathrm{~kg}$ of hydrogen fuel can run $400 \mathrm{~km}$ with zero carbon oxide emissions [5]. The energy efficiency of this hydrogen 'burnt' process via electrochemically combining with oxygen in fuel cell may reach $70 \%$ with less Carnot efficiency loss compared to that in an internal combustion engine [6]. However, the major obstacles for the advent of the hydrogen economy are the absence of efficient strategies for both hydrogen storage and production. Therefore, it is urgent to develop effective solutions to solve these problems from the view of the futuristic aspect of the utilization of hydrogen in stationary, portable and automotive applications [7-9].

As it is known, hydrogen storage methods generally are classified into three types: solid-, liquid- and gas-state. Though ultrahigh-pressure hydrogen and cryogenic-liquid hydrogen technologies are relatively mature and have been applied in various prototype vehicles [10], the hydrogen density barely meets the targets determined by the US Department of Energy (DOE) [11]. For ultrahigh-pressure hydrogen gas, the hydrogen-storage targets of DOE upon onboard hydrogen applications in terms of gravimetric and volumetric density are 1.6 and 2.1 times higher (Table 1), respectively, than the values achieved to date using common 700-bar tanks. As far as we know, only the state-of-the-art 700-bar hydrogen tank designed by Toyota holds a hydrogen density of approximately $5.7 \mathrm{wt} \% \mathrm{H}_{2}$ [12], just satisfying the present target of DOE. Ammonia $\left(\mathrm{NH}_{3}\right)$ is also highly valued as a potential hydrogen storage option except compressed $\mathrm{H}_{2}$ gas, owing to its high hydrogen density (17.8 wt\% and $0.120 \mathrm{~kg} \mathrm{H}_{2} \mathrm{~L}^{-1}$ for gravimetric and volumetric $\mathrm{H}_{2}$ density), low storage pressure and stability for long-term storage as well as high flexibility in its utilization [13]. In this regard, $\mathrm{NH}_{3}$ can fulfill the demand to store the energy in time (stationary energy storage) and in space (energy export and import). However, $\mathrm{NH}_{3}$ encounters high energy demand in both synthesis and decomposition for indirect utilization by the release of $\mathrm{H}_{2}$. In case of liquid $\mathrm{H}_{2}$, in spite of a much higher volumetric density $\left(0.071 \mathrm{~kg} \mathrm{H}_{2} \mathrm{~L}^{-1}\right)$ that even surpasses the ultimate targets of DOE at the temperature as low as $-253{ }^{\circ} \mathrm{C}$, the inevitable hydrogen loss resulted from heat transfer and a large amount of energy consumed to liquefy hydrogen severely impede its practical applications $[8,14]$. As same as liquid $\mathrm{H}_{2}$, besides the much unavoidable energy consumption required in the high-pressurized compression, the high cost and latent safety risks of hydrogen refueling stations are the obstacles for the large-scale utilization in civilian vehicles. Admittedly, solid hydrogen storage materials [15] are the most acceptable hydrogen carriers and have received a great deal of attentions due to their ideal hydrogen density, reliable safety and numerous modification methods that have been developed to tailor their practical dehydrogenation capacities in recent years. Here, a comparison of some typical hydrogen mediums in terms of cost, hydrogen storage capacity and safety is summarized, as shown in Table 2.

Table 1 Current states vs targets for onboard $\mathrm{H}_{2}$ storage for light-duty fuel cell vehicles [11]

\begin{tabular}{llll}
\hline Storage targets & $\begin{array}{l}\text { Gravimetric } \mathrm{kWh} \mathrm{kg}^{-1}\left(\mathrm{~kg} \mathrm{H}_{2} / \mathrm{kg}\right. \\
\text { system })\end{array}$ & $\begin{array}{l}\text { Volumetric } \mathrm{kWh} \mathrm{L}^{-1}\left(\mathrm{~kg} \mathrm{H}_{2} / \mathrm{L}\right. \\
\text { system })\end{array}$ & $\mathrm{Cost}^{1} \$ /{\mathrm{kWh}\left(\$ / \mathrm{kg} \mathrm{H}_{2}\right)}$ \\
\hline 2020 & $1.5(0.045)$ & $1.0(0.030)$ & $\$ 10(\$ 333)$ \\
2025 & $1.8(0.055)$ & $1.3(0.040)$ & $\$ 9(\$ 300)$ \\
Ultimate & $2.2(0.065)$ & $1.7(0.050)$ & $\$ 8(\$ 266)$ \\
$\begin{array}{l}\text { Current status } \\
\text { 700 bar compressed }\left(5.6 \mathrm{~kg} \mathrm{H}_{2} \text {, type IV, }\right. \\
\quad \text { single tank) }\end{array}$ & $1.4(0.042)$ & $0.8(0.024)$ & $\$ 15(\$ 500)$ \\
\hline
\end{tabular}

${ }^{1}$ Projected at 500,000 units/year

${ }^{2}$ FCTO Data Record \#15,013, 11/25/2015: https://www.hydrogen.energy.gov/pdfs/15013 onboard storage performance cost.pdf 
Table 2 A comparison between some typical lightweight materials and hydrogen mediums [16, 17]

\begin{tabular}{|c|c|c|c|c|c|c|}
\hline \multirow{3}{*}{$\begin{array}{l}\text { Parameters } \\
\text { Category } \\
\text { Compound }\end{array}$} & \multicolumn{4}{|l|}{ Solid } & \multicolumn{2}{|l|}{ Non-solid } \\
\hline & \multirow{2}{*}{$\begin{array}{l}\text { Metal hydride } \\
\mathrm{MgH}_{2}\end{array}$} & \multirow{2}{*}{$\begin{array}{l}\text { Complex hydride } \\
\mathrm{NaBH}_{4}\end{array}$} & \multicolumn{2}{|c|}{ Microporous adsorbents } & \multirow{2}{*}{$\begin{array}{l}\text { Liquid hydrogen } \\
\mathrm{H}_{2}\end{array}$} & \multirow{2}{*}{$\begin{array}{l}\text { ammonia } \\
\mathrm{NH}_{3}\end{array}$} \\
\hline & & & Activated carbon & MOF & & \\
\hline $\begin{array}{l}\text { Gravimetric capacity } \\
(\mathrm{wt} \%)\end{array}$ & 7.6 & 10.7 & $2.1-2.6$ & 6.1 & 1.4 & 1.89 \\
\hline $\begin{array}{l}\text { Volumetric capacity } \\
\left(\mathrm{g} \mathrm{L}^{-1}\right)\end{array}$ & 110 & 116 & 20 & 20 & 125 & 114 \\
\hline Cost & Low & High & Low & Low & Low & Low \\
\hline Thermolytic kinetics & Slow & Slow & Fast & Fast & Fast & Slow \\
\hline $\begin{array}{l}\mathrm{H}_{2} \text { release tempera- } \\
\text { ture }\left({ }^{\circ} \mathrm{C}\right)\end{array}$ & Very high $(>300)$ & Very high $(>500)$ & Low $(-196 \sim 25)$ & Cryogenic (-196) & -253 & $350-900$ \\
\hline Abundant & High availability & $\begin{array}{l}\text { Schlesinger or Bayer } \\
\text { method }\end{array}$ & High availability & High availability & High availability & High availability \\
\hline Safety & Benign & Benign & Benign & Benign & Benign & Toxic and corrosive \\
\hline
\end{tabular}

In the mid and late of 2000s, the heavy intermetallic binary compounds were initially emerged as hydrogen storage materials owing to their good cycling performance and rapid kinetics under moderate conditions. However, the $\mathrm{AB}_{2}$ and $\mathrm{AB}_{5}$ types $\left(\mathrm{ZrFe}_{2}, \mathrm{LaNi}_{5}\right.$, etc. $)$, representative members of heavy metal alloys family, merely enable $\leq 2$ wt $\%$ of hydrogen sorption because of the heavyweight and hydrogen non-absorptive trait of B side elements $9,18-19$. To meet the hydrogen storage targets given by DOE, scientists and researchers have been focusing toward novel lightweight hydrides [20-22]. Among these hydrogen materials, the most fascinating hydrides are magnesiumbased materials $\left(\mathrm{MgH}_{2}\right.$ as the host material) [23-25] and B-N compounds (borohydrides or ammonia borane) [26]. The gravimetric hydrogen densities of $7.6 \mathrm{wt} \%$ for $\mathrm{MgH}_{2}$ and $18.5 \mathrm{wt} \%$ for $\mathrm{LiBH}_{4}$ even exceed the value for onboard applications set by DOE. Recently, Shui's group [27] synthesized a multilayered $\mathrm{Ti}_{2} \mathrm{CT}_{\mathrm{x}}$ ( $\mathrm{T}$ is a functional group) stack by incomplete hydrofluoric acid (HF) etching, and the as-prepared $\mathrm{Ti}_{2} \mathrm{CT}_{\mathrm{x}}$ showed an unprecedented hydrogen uptake of $8.8 \mathrm{wt} \% \mathrm{H}_{2}$ at room temperature and 60 bar $\mathrm{H}_{2}$, which is much higher than the ultimate targets of DOE. Unfortunately, most of light metal-based materials are considered to be irreversible under mild conditions, so a serious of tailoring strategies have been developed for hydrolysis and thermolysis. For example, it was found that $\mathrm{ZrCl}_{4}$ is an effective catalyst to considerably reduce the dehydrogenation temperature and activation energy for $\mathrm{LiBH}_{4}$ [28]. Furthermore, the hydrogen produced by the thermal decomposition is always accompanied with the emission of other explosive or toxic gas such as $\mathrm{CO}$ and/ or $\mathrm{B}_{2} \mathrm{H}_{6}$ [29]. Generally, PEMFCs are very sensitive to the impurity of hydrogen, and even a little amount of impurity may cause the poisoning the catalysts [30]. Compared with the above approach, pure hydrogen supply from hydrolysis of light metal-based materials, including metal hydrides and borohydrides via reacting with water without external heat input, has a number of advantages, such as suitable operation temperature and well-controlled hydrogen release. Especially, hydrogen supply via hydrolysis is a self-humidification process, and such humid hydrogen can be conveyed directly into PEMFCs without dehumidification treatment and any performance loss [31]. Different from liquid $\mathrm{H}_{2}$ or gas-state hydrogen carriers that need further development and construction in infrastructures, such as the $\mathrm{NH}_{3} / \mathrm{H}_{2}$ pipelines, $\mathrm{H}_{2} / \mathrm{NH}_{3}$ refueling stations and liquefaction devices, the storage and transportation of metal hydrides and borohydrides hold low potential risk and low capital investment because they are largely compatible with the current transport infrastructure [13]. For Mg-based and Al-based materials, they can be stored and transported in the form of bulks. Moreover, the formation of a coherent passive layer deposited on the surface of bulks may prevent further oxidation of hydrolysable materials. With respect to borohydrides, $\mathrm{NaBH}_{4}$, an example of the family of borohydrides, is a well-known hydrogen carrier due to its high hydrogen-storage capacity $(10.8 \mathrm{wt} \%)$ $[32,33]$. It is easily dissolved in alkaline aqueous solution for safe, stable and long periods of storage, leading to a highly convenient transportation. Therefore, the currently 
available storage and transportation facilities and their regulation can be well utilized to increase the readiness for the adoption of light metal-based materials.

Hydrolysis enables hydrogen extraction from liquid water. However, the performance of hydrolysis reaction is subject to the operation temperature. The hydrogen generation rate will be significantly reduced in a low-temperature climate and the hydrolysis process could even be directly frozen in subzero circumstances. Methanol has a very low freezing point $\left(-97^{\circ} \mathrm{C}\right)$; thus, hydrogen supply from methanolysis is considered optimal for real-time hydrogen production in low-temperature climate or subzero areas. At mild conditions, the reversible hydrogen storage systems like the metal-based hydrides have the advantages of fast hydrogen injection and durability for repeated recycling, whereas the hydrogen storage properties are plagued by the sluggish de-/ hydrogenation kinetics, thermodynamic barriers (de-/rehydrogeneration temperature $<100{ }^{\circ} \mathrm{C}$, pressure $<10 \mathrm{~atm}$ ) and cyclic performance [34]. In contrast, the device for hydrolysis hydrogen supply is very compact [35], and the hydrogen derived from water or light metal-based materials can be directly connected to the fuel cell to drive the motor. Significantly, water freight is safer and more convenient compared to high-pressure hydrogen storage and transportation. However, the controllability and utilization of enormous exothermicity of hydrolysis require further investigations.

In this review, we summarize the recent progress in the development of hydrolysis and alcoholysis of light metalbased materials, especially the Mg-/Al-based materials and borohydrides. To overcome the sluggish hydrolysis and low conversion, various methods have been developed, such as ball milling, catalysis, alloying, and solution modification. The different hydrolysis mechanisms of $\mathrm{Al} / \mathrm{Mg}$-based materials and sodium borohydride are discussed in detail. Furthermore, the recent advances in $\mathrm{NaBH}_{4}$ regeneration process from hydrolysis by-product are discussed. $\mathrm{NaBH}_{4}$ is considered as the most potential hydrolysable material.

\section{Hydrogen Generation from Hydrolysis or Alcoholysis}

The typical hydrolytic materials include metals/hydrides, ammonia borane $\left(\mathrm{NH}_{3} \mathrm{BH}_{3}\right.$, denoted as $\left.\mathrm{AB}\right)$ and borohydrides. Hydrogen supply from $\mathrm{NaBH}_{4}$ hydrolysis was the most widely studied and has numerous advantages over the other hydrolytic materials, including half of hydrogen production from water, low operation temperature, environmentally benign by-product, well-controlled and high-purity hydrogen release [36-38], making it promising for on-board or onsite hydrogen supply. On the other hand, Mg- or Al-based materials are also widely discussed as hydrogen carriers, and they can supply high-purity $\mathrm{H}_{2}$ according to real-time demands via contacting with water. Compared to costly borohydrides, hydrogen supply from the light-metal materials is affordable and sustainable because of the abundant content in the earth crust and the mature recycling process in the industry. The following sections mainly emphasize the hydrolysis/alcoholysis of borohydrides, Mg-/Al-based alloys and hydrides.

\subsection{Highly Efficient Catalytic and Non-catalytic Alcoholysis/Hydrolysis of Borohydrides}

Extensive efforts have been devoted to exploring highly efficient hydrolysis of borohydrides $\left(\mathrm{NaBH}_{4}, \mathrm{Mg}\left(\mathrm{BH}_{4}\right)_{2}\right.$, $\mathrm{LiBH}_{4}$, etc.) or $\mathrm{AB}$ due to their excellent hydrogen storage capacities ${ }^{39-41}$. For hydrogen application in fuel cells, if the water produced in the fuel cell part is redirected to $\mathrm{LiBH}_{4}$, then the $\mathrm{H}_{2}$ generation capacity may increase to $37.0 \mathrm{wt} \%$ [42]. Compared with the expensive $\mathrm{LiBH}_{4}, \mathrm{NaBH}_{4}$ with a $21.1 \mathrm{wt} \% \mathrm{H}_{2}$ generation capacity (the water produced in the fuel cell part is recycled to react with $\mathrm{NaBH}_{4}$ and it is not taken into account in the case) is preferred as a more superior hydrolysable material, but its hydrolysis suffers from sluggish kinetics in neutral aqueous solutions. To lower the high kinetic barrier to an extent that would give a hydrogen generation rate closing to the requirement of practical applications, a variety of non-noble metal catalysts have been developed, such as $\mathrm{Fe}, \mathrm{Co}, \mathrm{Ni}$ or Pt, Ru, and Pd [43-47]. Especially, in the hydrolysis of borohydride aided by $\mathrm{M}_{3} \mathrm{~B}$ $(\mathrm{M}=\mathrm{Cu}, \mathrm{Ni}, \mathrm{Fe})$, the catalytic activities are in the order of $\mathrm{Cu}<\mathrm{Ni}<\mathrm{Co}$ [48]. The Co-B-based types [49-52] are commonly admitted as reactive as noble metals and much more cost-effective, which exhibit saltant performance improvements. The enhanced performance results from the Co-B catalysts loaded on supports with a high surface distribution, where transition metals $(\mathrm{Co}, \mathrm{Ni}$, and $\mathrm{Fe}$ ) act as active sites. The real hydrolysis by-product of $\mathrm{NaBH}_{4}$ is $\mathrm{NaBO}_{2} \cdot \mathrm{xH}_{2} \mathrm{O}$, and the real-time hydrolysis reaction is given as follows [53]: 
$\mathrm{NaBH}_{4}+(2+x) \mathrm{H}_{2} \mathrm{O} \rightarrow \mathrm{NaBO}_{2} \cdot x \mathrm{H}_{2} \mathrm{O}+4 \mathrm{H}_{2}$

That is, $\mathrm{NaBH}_{4}$ could produce four equivalents of hydrogen through the hydrolysis process. Recently, AppiahNtiamoah et al. [54] synthesized a novel catalyst with a core-shell structure, where Co was loaded upon $\mathrm{Fe}_{3} \mathrm{O}_{4} @ \mathrm{C}$ "active" support. The unique properties of the "active" $\mathrm{Fe}_{3} \mathrm{O}_{4} @ \mathrm{C}$ promoted a synergistic catalytic reaction involving $\mathrm{Co}, \mathrm{Fe}_{3} \mathrm{O}_{4}$, and $\mathrm{C}$ during $\mathrm{NaBH}_{4}$ hydrolysis as shown in Fig. 1, delivering a hydrogen generation rate up to $1746 \mathrm{~mL}$ $(\mathrm{g} \mathrm{min})^{-1}$. Holbrook [55] believed that the hydrolysis mechanism with transition catalyst could be classified into five steps as shown in Fig. 1a. Firstly, the chemisorption of $\mathrm{BH}_{4}{ }^{-}$on the metal atom site produces $\mathrm{M}-\mathrm{BH}_{3}$ and $\mathrm{M}-\mathrm{H}$ (step 1-3). Then, an electron from $\mathrm{M}-\mathrm{BH}_{3}$ is transferred to the $\mathrm{M}$ site and $\mathrm{BH}_{3}$ is discarded, so the electronegative $\mathrm{M}$ site attracts $\mathrm{H}^{+}$in water to form a new $\mathrm{M}-\mathrm{H}$. And a consumption of the two $\mathrm{M}-\mathrm{H}$ can release one $\mathrm{H}_{2}$ molecule, then the $\mathrm{BH}_{3}$ legacy and $\mathrm{OH}-$ will form $\mathrm{BH}_{3}(\mathrm{OH})^{-}$(step 4-5). Subsequently, the stable intermediate $\mathrm{BH}_{3}(\mathrm{OH})^{-}$successively provides three active hydrogens, which will attack three $\mathrm{H}_{2} \mathrm{O}$ to form $\mathrm{BOH}_{4}{ }^{-}$finally and release $3 \mathrm{~mol}$ of $\mathrm{H}_{2}$ (step 5-6). However, $\mathrm{Fe}$ exposed in the pores and Co could also from $\mathrm{Fe}_{3} \mathrm{O}_{4} @ \mathrm{C}-\mathrm{Co}$ to catalyze hydrogen release according to the mechanism proposed by Pena-Alonso via a synergistic effect as shown in Fig. 1b where hydrogen is firstly produced in the $3^{\text {rd }}$ step, and the entire reaction path is shortened. Moreover, the reusability and stability of $\mathrm{Fe}_{3} \mathrm{O}_{4} @ \mathrm{C}-\mathrm{Co}$ composite were investigated via successive catalytic runs, and there was negligible loss in the amount of $\mathrm{H}_{2}$ generated after 5 runs. The $\mathrm{Fe}_{3} \mathrm{O}_{4} @ \mathrm{C}-\mathrm{Co}$ composite showed high recyclability performance in catalytic activity and structural integrity, signifying its real-life application prospects. Furthermore, Patel's team [56] doped with various transition metals in Co-B-based binary catalysts and explored the hydrolysis properties as shown in Fig. 2. The Co-B-based ternary or quaternary catalysts may display better catalytic activity than binary catalysts. Table 3 summarizes recent advances on Cobased catalysts and their catalytic performances for $\mathrm{NaBH}_{4}$ hydrolysis. More information and applications about hydrogen production from $\mathrm{NaBH}_{4}$ for fuel-cell systems could be referred from a recent review [57].

$\mathrm{AB}$ is considered as a leading contender in promising chemical hydrogen-storage materials for various applications due to its high hydrogen density (19.6 wt\%) and high stability both in solid state and solution under ambient conditions, as well nontoxicity and high solubility $[33,73]$. It can release three equivalents of hydrogen vis thermolysis, but the third-step dehydrogenation requires more than $1200{ }^{\circ} \mathrm{C}$. Similarly, the developed catalysts for the hydrolysis of $\mathrm{NaBH}_{4}$, such as noble metal-based NPs and Co-based NPs deposited on supports, can also impel AB hydrolysis as well. Li et al. [74] synthesized CVD-Ni/ZIF-8 by chemical vapor deposition, which could promote ammonia borane to release 3 equivalents of hydrogen in $13 \mathrm{~min}$. Later, Wang et al. [75] deposited Ni NPs in ZIP-8 by $\mathrm{NaBH}_{4}$ reduction method, which promoted $\mathrm{AB}$ to complete reaction in $0.3 \mathrm{M}$ $\mathrm{NaOH}$ solution within $5 \mathrm{~min}$ with a TOF value of $85.7 \mathrm{~mol}_{\mathrm{H} 2}$ $\mathrm{mol}_{\text {cat }}{ }^{-1} \mathrm{~min}^{-1}$. Interestingly, it was found that $\mathrm{H}^{+}$in the acid could slow the reaction, and a certain concentration of $\mathrm{OH}^{-}$remarkably improved hydrogen evolution. Therefore, a switch was designed to control hydrogen supply by adjusting the $\mathrm{pH}$ value of the solution. In addition, the reusability of the nanocatalyst NiNPs/ZiF-8 was examined by the continuous addition of a new proportion of $\mathrm{AB}$ aqueous solution when the previous run was completed. It was found that the activity of NiNPs/ZiF-8 was essentially retained until the fifth run and there was almost no loss in the amount of $\mathrm{H}_{2}$ generated during the cycling test. $\mathrm{He}$ et al. [76] also got the same result that $\mathrm{OH}^{-}$in aqueous solution is crucial in determining the hydrolysis kinetics of $\mathrm{AB}$ through the kinetic isotope effect (KIE). Wang et al. [77] further explored the hydrolysis mechanism of $\mathrm{Ni}_{2} \mathrm{Pt} @ \mathrm{ZIF}-8$ and found that $\mathrm{OH}^{-}$acted as a catalyst promoter, making the NP more electron-rich, which could favor the oxidative addition of water, as shown in Fig. 3. The presence of $\mathrm{OH}^{-}$boosts $\mathrm{H}_{2}$ evolution that becomes 87 times faster than in its absence with $\mathrm{Ni}_{2} \mathrm{Pt} @ \mathrm{ZiF}-8$. The kinetic isotope effects using $\mathrm{D}_{2} \mathrm{O}$ showed that cleavage by oxidative addition of an $\mathrm{O}-\mathrm{H}$ bond of water onto the catalyst surface is the rate-determining step of this reaction, enabling significant progress in catalyst design toward convenient $\mathrm{H}_{2}$ generation from hydrogen-rich substrates in the near future.

Although the introduction of the catalyst can enhance the reaction to some extent, the difficulty and cost in recovering the catalyst, however, is an issue. Therefore, it is required to develop catalyst-free hydrogen supply systems from lightmetal-based materials. Recently, Ouyang and co-workers investigated the non-catalytic hydrolysis of some borohydrides $[36,78,79]$. For instance, they found that the hydrogen generation rate for $\mathrm{NaBH}_{4}$ hydrolysis could be accelerated by doping with $\mathrm{ZnCl}_{2}$ without involving catalysts. It was 
(a)
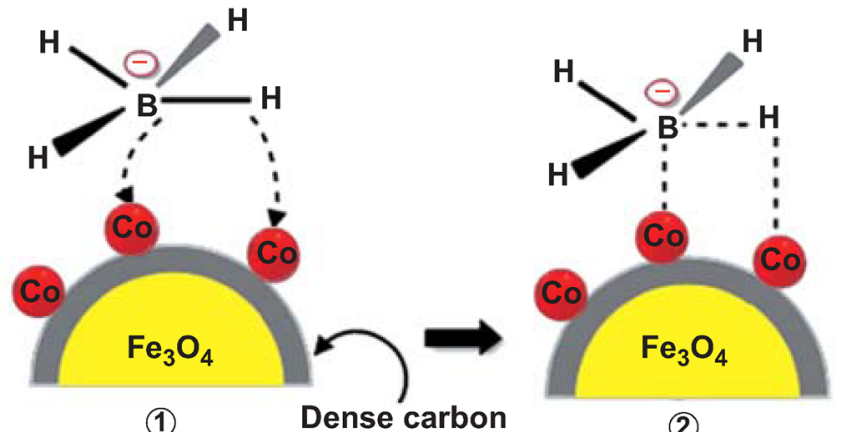

(2)

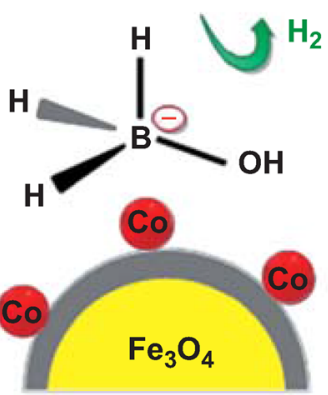

(5)

(b)

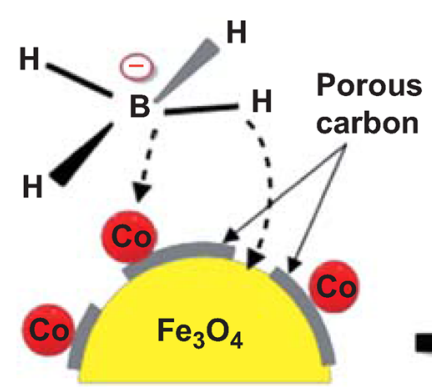

(1)

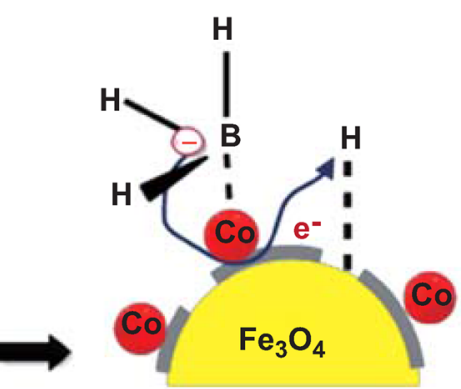

(2)

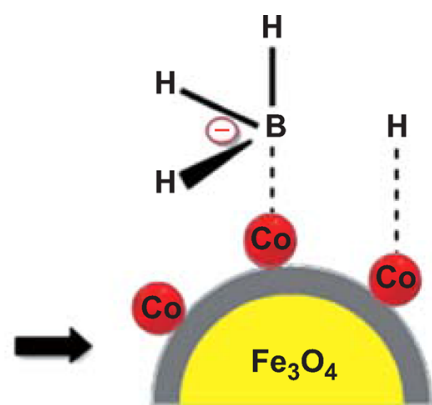

(3)

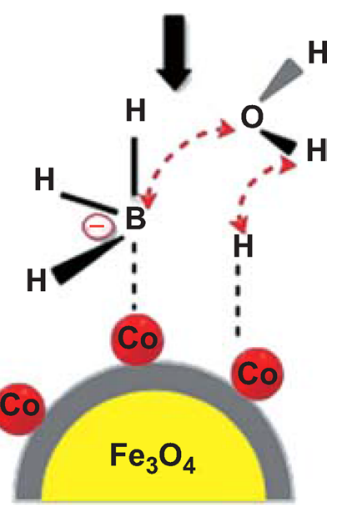

(4)

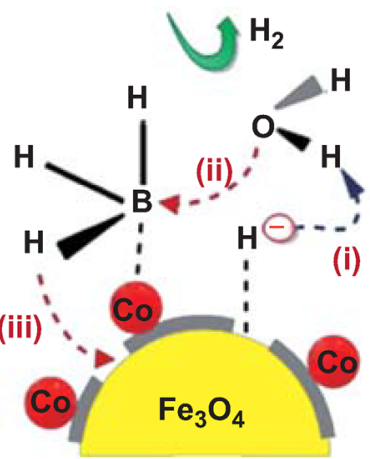

(3)

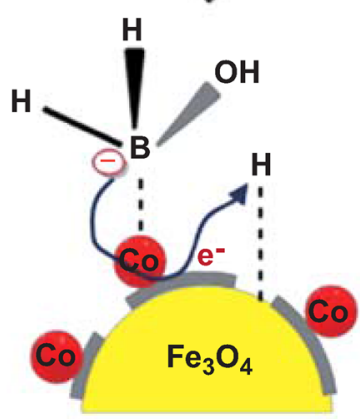

(4)

Fig. 1 Schematic illustration for $\mathrm{NaBH}_{4}$ hydrolysis on a $\mathrm{Fe}_{3} \mathrm{O}_{4} @ \mathrm{C}-\mathrm{Co}$ and, $\mathbf{b} \mathrm{Fe}_{3} \mathrm{O}_{4} @ \mathrm{C}-\mathrm{X}-\mathrm{Co}(\mathrm{X}=$ temperature). Reprinted with permission from Ref. [54]. Copyright 2019 Elsevier 

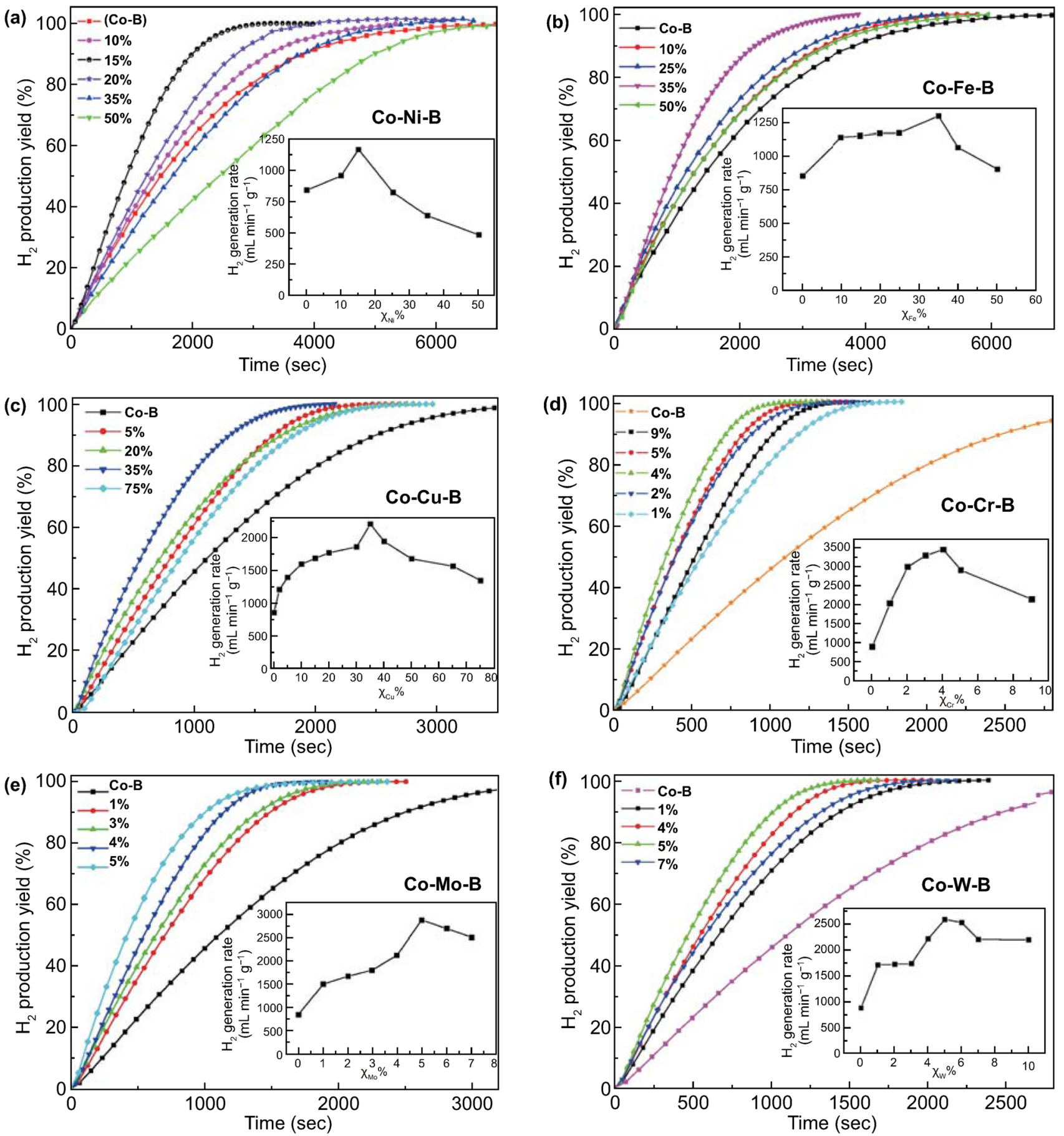

Fig. 2 Hydrogen generation yield as a function of reaction time obtained by hydrolysis of alkaline $\mathrm{NaBH}_{4}(0.025 \mathrm{M})$ with a Co-Ni-B, b Co$\mathrm{Fe}-\mathrm{B}, \mathbf{c} \mathrm{Co}-\mathrm{Cu}-\mathrm{B}, \mathbf{d} \mathrm{Co}-\mathrm{Cr}-\mathrm{B}$, e Co-Mo-B, and $\mathbf{f} \mathrm{Co}-\mathrm{W}-\mathrm{B}$ with different $\chi_{\mathrm{M}}$ values (where $\mathrm{M}=\mathrm{Ni}, \mathrm{Fe}, \mathrm{Cu}, \mathrm{Cr}, \mathrm{Mo}$, and $\mathrm{W}$ ). Insets show the maximum $\mathrm{H}_{2}$ generation rate $\left(R_{\max }\right)$ as a function of $\chi_{\mathrm{M}}$. Reprinted with permission from Ref. [56]. Copyright 2010 Elsevier

found that $\mathrm{NaBH}_{4}-35 \mathrm{wt} \% \mathrm{ZnCl}_{2}$ achieved the optimal hydrogen yield of $1964 \mathrm{~mL} \mathrm{~g}^{-1} \mathrm{H}_{2}$ with a considerable hydrogen production rate of $1124 \mathrm{~mL} \mathrm{~g}^{-1}$ within only $5 \min$ [79].
Interestingly, they observed the existence of $\mathrm{NaZn}\left(\mathrm{BH}_{4}\right)_{3}$ (Fig. 4) after ball milling the mixture of $\mathrm{NaBH}_{4}-\mathrm{ZnCl}_{2}$ and further investigated the hydrolysis performance of pure 
Table 3 Comparison of some Co-based catalysts and their catalytic performance for $\mathrm{NaBH}_{4}$ hydrolysis

\begin{tabular}{|c|c|c|c|c|}
\hline Catalyst & $\begin{array}{l}\mathrm{HGR}\left(\mathrm{mL} \mathrm{H}_{2}\left(\mathrm{~g}_{\text {cat }}\right.\right. \\
\left.\min )^{-1}\right)\end{array}$ & Preparation method & $\begin{array}{l}\text { Activation energy } \\
\left(\mathrm{kJ} \mathrm{mol}^{-1}\right)\end{array}$ & Refs. \\
\hline $\mathrm{Fe}_{3} \mathrm{O}_{4} @ \mathrm{C}-\mathrm{Co}$ & 1746 & Hydrothermal method-thermal treatment & 47.3 & {$[54]$} \\
\hline $\mathrm{Co}-\mathrm{Fe}_{3} \mathrm{O}_{4}-\mathrm{CNT}$ & 1213 & Stepwise precipitation-microwave-assisted reduction & 42.8 & {$[58]$} \\
\hline $\mathrm{PAN} / \mathrm{CoCl}_{2}-\mathrm{CNT}$ nanofibers & 1255 & Electrospinning & 52.9 & [59] \\
\hline $\mathrm{Co} / \mathrm{Fe}_{3} \mathrm{O}_{4} @ \mathrm{C}$ & 1403 & Wetness impregnation-chemical reduction & 49.2 & [44] \\
\hline $\mathrm{Co}_{3} \mathrm{O}_{4}$ macrocubes & 1498 & Hydrothermal method & 48.0 & {$[60]$} \\
\hline $\mathrm{Co}_{3} \mathrm{O}_{4} \mathrm{NA} / \mathrm{Ti}$ & 1940 & Hydrothermal treatment-annealing & 59.8 & {$[61]$} \\
\hline $\mathrm{Co}-\mathrm{B} / \mathrm{AT}$ & 1420 & Impregnation-chemical reduction method & 56.32 & [49] \\
\hline $\mathrm{CoB} / \mathrm{o}-\mathrm{CNTs}$ & 3041 & Wetness impregnation-chemical reduction & 37.6 & {$[50]$} \\
\hline Co-La-Zr-B nanoparticle & 102 & Chemical reduction & 51.00 & {$[62]$} \\
\hline $\mathrm{p}(\mathrm{AAm})-\mathrm{Co}$ & 1926 & photopolymerization technique & 39.7 & {$[63]$} \\
\hline $\mathrm{NiCo}_{2} \mathrm{O}_{4}$ hollow sphere & 1000 & Hydrothermal method & 52.2 & {$[64]$} \\
\hline Carbon black supported Co-B & 8034 & Reduction-precipitation route & 56.7 & {$[65]$} \\
\hline $\mathrm{LiCoO}_{2} / \mathrm{Ru}$ & 3000 & Microwave-assisted polyol process & 70.4 & {$[45]$} \\
\hline $\mathrm{Co}-\mathrm{Ni}-\mathrm{B} / \mathrm{Cu}$ sheet & 14,778 & Electroless plating & 42.8 & [51] \\
\hline $\mathrm{Co}-\mathrm{W}-\mathrm{P} / \mathrm{Cu}$ sheet & 5000 & Electrodeposition & 22.8 & {$[66]$} \\
\hline $\mathrm{Ru}-\mathrm{SZ}$ & 9100 & Sol-gel method & 76 & [46] \\
\hline $\mathrm{Co}-\mathrm{Ni}-\mathrm{Mo}-\mathrm{P} / \gamma-\mathrm{Al}_{2} \mathrm{O}_{3}$ & 10,125 & Electroless deposition & 52.4 & {$[67]$} \\
\hline $\mathrm{Co}-\mathrm{B} / \mathrm{TiO}_{2}$ & 12,503 & Chemical reduction & 51.6 & {$[52]$} \\
\hline $\mathrm{Co}-\mathrm{P} / \mathrm{Cu}$ sheet & 2275.1 & Electroless plating & 27.9 & {$[68]$} \\
\hline $\mathrm{CoeP} / \mathrm{Cu}$ sheet & 3300 & Electroless plating & 60.2 & [69] \\
\hline $\mathrm{Co}-\mathrm{P} / \mathrm{Cu}$ sheet & 5956 & Electroplating & 23.9 & [70] \\
\hline Flower-like $\mathrm{Co}-\mathrm{P}$ & 1647.9 & Electroless plating & 47.0 & [71] \\
\hline $\mathrm{Co}-\mathrm{Mo}-\mathrm{Pd}-\mathrm{B}$ & 6023 & Chemical reduction & 36.4 & [72] \\
\hline
\end{tabular}

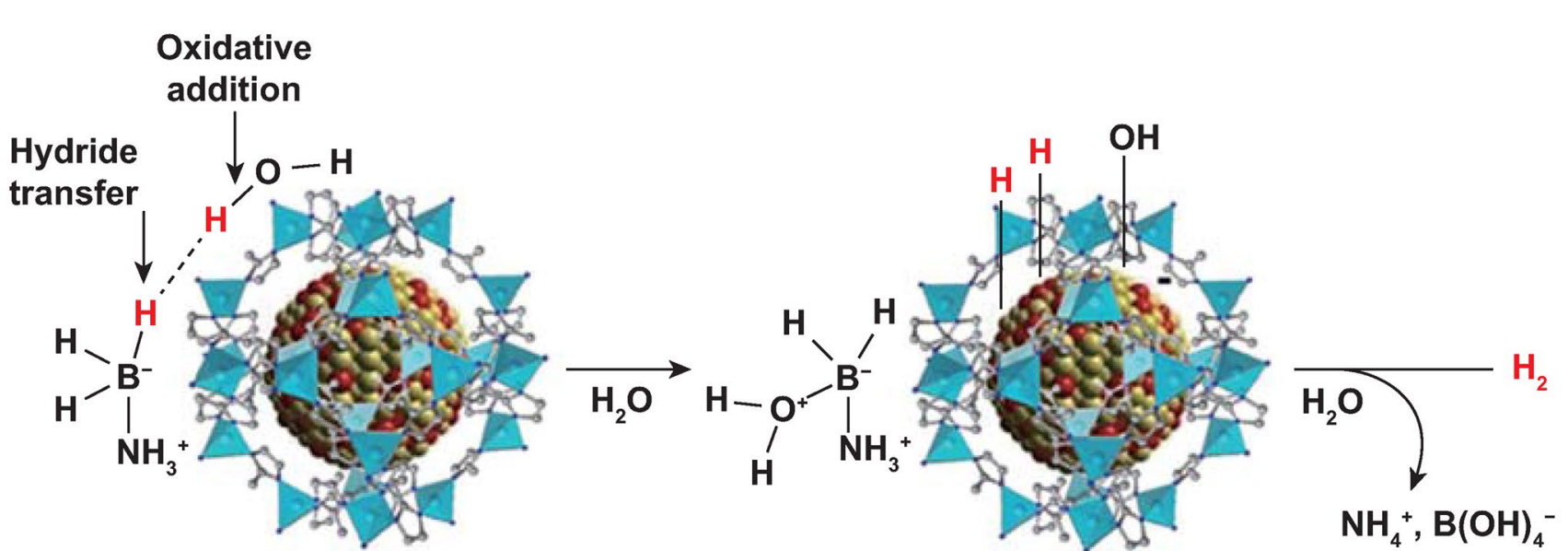

Fig. 3 Proposed mechanism for the hydrolysis of AB catalyzed by NiPt@ZIF-8. Reprinted with permission from Ref. [77]. Copyright 2018 American Chemical Society

$\mathrm{NaZn}\left(\mathrm{BH}_{4}\right)_{3}$ [36]. The results showed that $\mathrm{NaZn}\left(\mathrm{BH}_{4}\right)_{3}$ enabled the hydrogen release of $1740 \mathrm{~mL} \mathrm{~g}^{-1}$ in $5 \mathrm{~min}$ with a total hydrogen yield up to $97 \%$. Because the ligands neighboring the metal cations in the borohydride involve the hydrogen elimination barrier and the stability of $\mathrm{BH}_{4}^{-}$[80], they introduced $\mathrm{NH}_{3}$ to achieve a rate-controlled hydrogen supply of $\mathrm{NaZn}\left(\mathrm{BH}_{4}\right)_{3}$ by forming its ammoniate. Similarly, they also studied the effect of ammonia complex number 

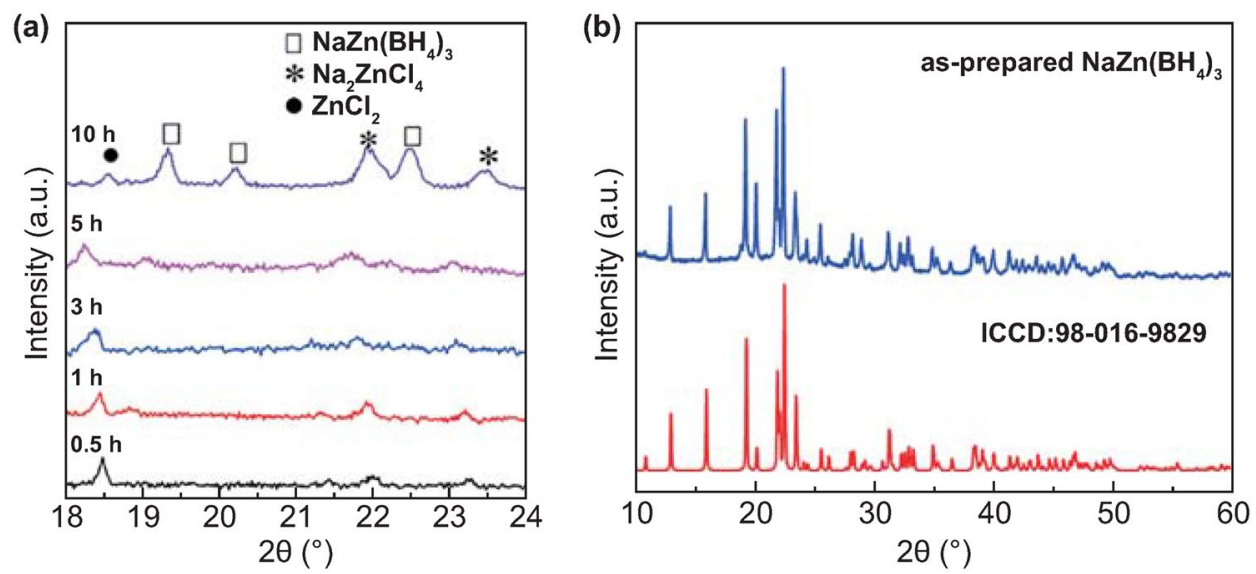

Fig. 4 XRD patterns of a $\mathrm{NaBH}_{4}-\mathrm{ZnCl}_{2}$ composites ball-milled for different durations. Reprinted with permission from Ref. [79], Copyright 2017 Elsevier, and b purified $\mathrm{NaZn}\left(\mathrm{BH}_{4}\right)_{3}$ and its standard PDF card. Reprinted with permission from Ref. [36], Copyright 2017 Royal Society of Chemistry

on hydrogen production kinetics by $\mathrm{Mg}\left(\mathrm{BH}_{4}\right)_{2}$ hydrolysis [78]. Obviously, the hydrogen evolution behaviors could be well-controlled via altering ammonia complex number upon $\mathrm{Mg}\left(\mathrm{BH}_{4}\right)_{2}$, whereas it sacrificed hydrogen yield. The hydrogen yields of $\mathrm{Mg}\left(\mathrm{BH}_{4}\right)_{2} \cdot 0.5 \mathrm{NH}_{3}, \mathrm{Mg}\left(\mathrm{BH}_{4}\right)_{2} \cdot \mathrm{NH}_{3}$, $\mathrm{Mg}\left(\mathrm{BH}_{4}\right)_{2} \cdot 2 \mathrm{NH}_{3}, \mathrm{Mg}\left(\mathrm{BH}_{4}\right)_{2} \cdot 3 \mathrm{NH}_{3}$, and $\mathrm{Mg}\left(\mathrm{BH}_{4}\right)_{2} \cdot 6 \mathrm{NH}_{3}$ are 2376, 2029, 1780, 1665, and $1180 \mathrm{~mL}\left(\mathrm{H}_{2}\right) \mathrm{g}^{-1}$, respectively. Similarly, $\mathrm{Mg}\left(\mathrm{BH}_{4}\right)_{2}$ can possess different hydrolytic behaviors when coordinated with various organic ligands (including $\mathrm{Mg}\left(\mathrm{BH}_{4}\right)_{2} \times \mathrm{xE}_{2} \mathrm{O}, \mathrm{Mg}\left(\mathrm{BH}_{4}\right)_{2} \times$ diglyme and $\mathrm{MgBH}_{4} \times 3 \mathrm{THF}$ ), with the larger the ligand and the higher the denticity, and the smaller amount of $\mathrm{B}_{2} \mathrm{H}_{6}$ being produced [81].

As is well known, the hydrogen generation performance would deteriorate markedly followed by temperature decrease. To solve this issue, alcoholysis and alcoholysis/hydrolysis composite hydrogen generation systems for $\mathrm{NaBH}_{4}$ have been developed [37, 82-85]. For example, hydrogen release from $\mathrm{NaBH}_{4}$ in ethylene glycol/water solutions in the presence of $\mathrm{CoCl}_{2}$ catalyst could be quickly launched even at $-10 \sim 20{ }^{\circ} \mathrm{C}$, fulfilling $100 \%$ of fuel conversion within only a few minutes. What's more, the hydrogen density of the alcoholysis/ hydrolysis composite system with optimized composition may reach $4 \mathrm{wt} \%$. This demonstrated that a superior-performance hydrogen generation system with a wide range of operational temperature may be developed for practical hydrogen source for mobile/portable applications [37].

For $\mathrm{LiBH}_{4}$ hydrolysis, the catalyst-free hydrolysis reaction never surpasses $50 \%$ of its theoretical yield due to the low solubility of the $\mathrm{LiBO}_{2}$-based by-product in water that deposits on $\mathrm{LiBH}_{4}$ and limits the full utilization of the hydride [86]. Kojima et al. [87] reported that the hydrogen densities increased with the increase in the dropped water $\left(\mathrm{H}_{2} \mathrm{O} / \mathrm{LiBH}_{4}\right)$ and followed by a reduction. These densities may show maximum values at $\mathrm{H}_{2} \mathrm{O} / \mathrm{LiBH}_{4}=1.3$. To enhance the sluggish kinetics and low conversion efficiency for $\mathrm{LiBH}_{4}$ hydrolysis, a series of strategies have been adopted toward $\mathrm{H}_{2}$ release at approximately a stoichiometric equivalent, including the hydrolysis system of $\mathrm{LiBH}_{4}$ doped with multiwalled carbon nanotubes (MWCNTs) [88] or diethyl ether addition [89], the non-catalytic hydrolysis of $\mathrm{LiBH}_{4} / \mathrm{NH}_{3} \mathrm{BH}_{3}$ composite system [90], and the catalytic hydrolysis reaction system of $\mathrm{LiBH}_{4}$ solution over nano-sized platinum dispersed on $\mathrm{LiCoO}_{2}$ $\left(\mathrm{Pt}-\mathrm{LiCoO}_{2}\right)$ [91], etc. Considering the affordability and sustainability, it is imperative to develop low-cost and nonnoble metal catalysts that hold similar activity and stability with noble metals in the conversion and utilization of $\mathrm{LiBH}_{4}$ hydrolysis system. Recently, Zhu's group [92] firstly adopted the transition-metal chlorides $\left(\mathrm{CoCl}_{2}, \mathrm{NiCl}_{2}, \mathrm{FeCl}_{3}\right)$ to promote the hydrolysis behaviors of $\mathrm{LiBH}_{4}$. Among the above catalysts, $\mathrm{CoCl}_{2}$ showed faster hydrogen kinetics, delivering a hydrogen generation rate ranging from 421 to $41,701 \mathrm{~mL} \mathrm{H}_{2}$ $\min ^{-1} \mathrm{~g}^{-1}$ with a maximum conversion of $95.3 \%$. These values are much higher than the value of $225 \mathrm{~mL} \mathrm{H}_{2} \min ^{-1} \mathrm{~g}^{-1}$ with Pt-LiCoO 2 . Moreover, $\mathrm{NH}_{3}$ was introduced to tailor the uncontrollable kinetics of $\mathrm{LiBH}_{4}$ by forming its ammoniates $\left(\mathrm{LiBH}_{4} \cdot \mathrm{xNH}_{3}, \mathrm{x}=1,2,3\right)$. In the presence of $\mathrm{CoCl}_{2}$, $\mathrm{LiBH}_{4} \cdot \mathrm{xNH}_{3}$ could stably release over $4300 \mathrm{~mL} \mathrm{H}_{2} \mathrm{~g}_{\mathrm{LiBH}}{ }^{-1}$ 
with a hydrogen capacity of $\sim 7.1 \mathrm{wt} \%$ and a $\mathrm{H}_{2}$ yield of $97.0 \%$, while it reacts with a stoichiometric amount of $\mathrm{H}_{2} \mathrm{O}$. However, the difficulty in regenerating the utilized $\mathrm{LiBH}_{4}$ and the associated high cost hamper their large-scale applications. In the near future, developing convenient and economical methods for $\mathrm{LiBH}_{4}$ regeneration is a linchpin, as it acts as hydrogen carrier in off-/on-board applications.

\subsection{Hydrogen Production via Hydrolysis of Mg-based Alloys or Its Hydrides}

Compared to borohydrides, the hydrolysis from light metals and metal hydrides for down-to-earth hydrogen supply has a number of advantages, including low-cost, abundant element contents, environmentally benign products of oxidation, etc. [38, 93-95]. Generally, it is widely accepted that the hydrolysis reaction of $\mathrm{Mg}$ or $\mathrm{MgH}_{2}$ is rapidly interrupted by a passive $\mathrm{Mg}(\mathrm{OH})_{2}$ layer deposited on the surface of Mg-based materials, leading to poor hydrolysis performance. To date, numerous methods, such as ball milling, alloying, aqueous solution modification or catalysis [96-99], have been applied to enhance the sluggish kinetics. Recently, Ouyang' group [100] synthesized flower-like $\mathrm{MoS}_{2}$ spheres via a one-step hydrothermal method. The as-prepared $\mathrm{MoS}_{2}$ composes of many uniform spherical nanoparticles (Fig. 5), resulting in larger surface areas than its bulk counterpart. The Mg-10 $\mathrm{wt} \% \mathrm{MoS}_{2}$ composite could release over $90 \%$ of theoretical hydrogen capacity in $1 \mathrm{~min}$. Also, they investigated the catalytic effects of the transition metal Mo and its compounds $\left(\mathrm{MoS}_{2}, \mathrm{MoO}_{2}\right.$, and $\left.\mathrm{MoO}_{3}\right)$ upon hydrolysis of $\mathrm{Mg}$ in seawater [99]. The results showed that the distribution of $\mathrm{MoS}_{2}$ catalyst in the Mg matrix became increasingly homogeneous with the increase in milling time (Fig. 6). The unique structure and uniformly dispersed $\mathrm{MoS}_{2}$ could significantly accelerate the hydrolysis process of $\mathrm{Mg}$. Moreover, the reusability and stability of $\mathrm{MoS}_{2}$ were investigated via successive catalytic runs. As shown in Fig. 7, there was a slight drop in the amount of $\mathrm{H}_{2}$ generated after 5 runs, and the catalytic activity of retrieved $\mathrm{MoS}_{2}$ was completely retained without decrease in $\mathrm{H}_{2}$ evolution rate. They believed that the markedly enhanced activity could be attributed to the synergistic effect of grinding and the galvanic corrosion between Mg- and Mo-based additives.

In addition to doping catalysts, alloying and ball milling have been proved to be effective means to enhance the hydrolysis performance of Mg. Ouyang et al. [97, 102-106] systematically studied the hydrolysis behaviors of Mg-RE alloy and its hydrides. They found that rareearth elements could facilitate the hydrogen absorption of Mg-based alloys, resulting in higher hydrogen yields for the hydrolysis of hydrogenated Mg-RE. Ma et al. [107] revealed that Ni could promote the hydrogenation of $\mathrm{CaMg}_{1.9} \mathrm{Ni}_{0.1}$ under room temperature, as opposed to $450{ }^{\circ} \mathrm{C}$ for pure $\mathrm{CaMg}_{2}$. Thus, the $\mathrm{H}-\mathrm{CaMg}_{1.9} \mathrm{Ni}_{0.1}$ could achieve a hydrogen yield of $1053 \mathrm{~mL} \mathrm{~g}^{-1}$ in only $12 \mathrm{~min}$,
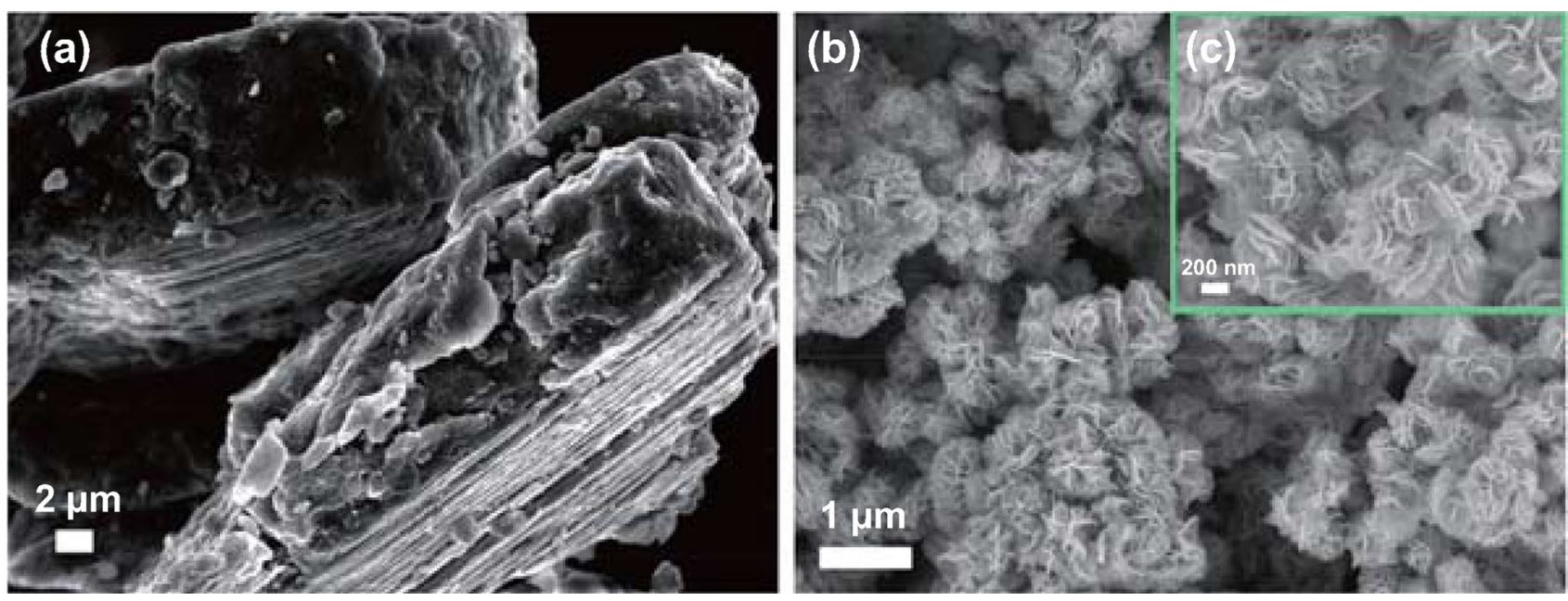

Fig. 5 SEM images of a bulk and $\mathbf{b}$ as-prepared $\mathrm{MoS}_{2}$, c high-magnification SEM image showing a small zone of the as-prepared MoS 2 . Reprinted with permission from Ref. [100]. Copyright 2017 Elsevier 

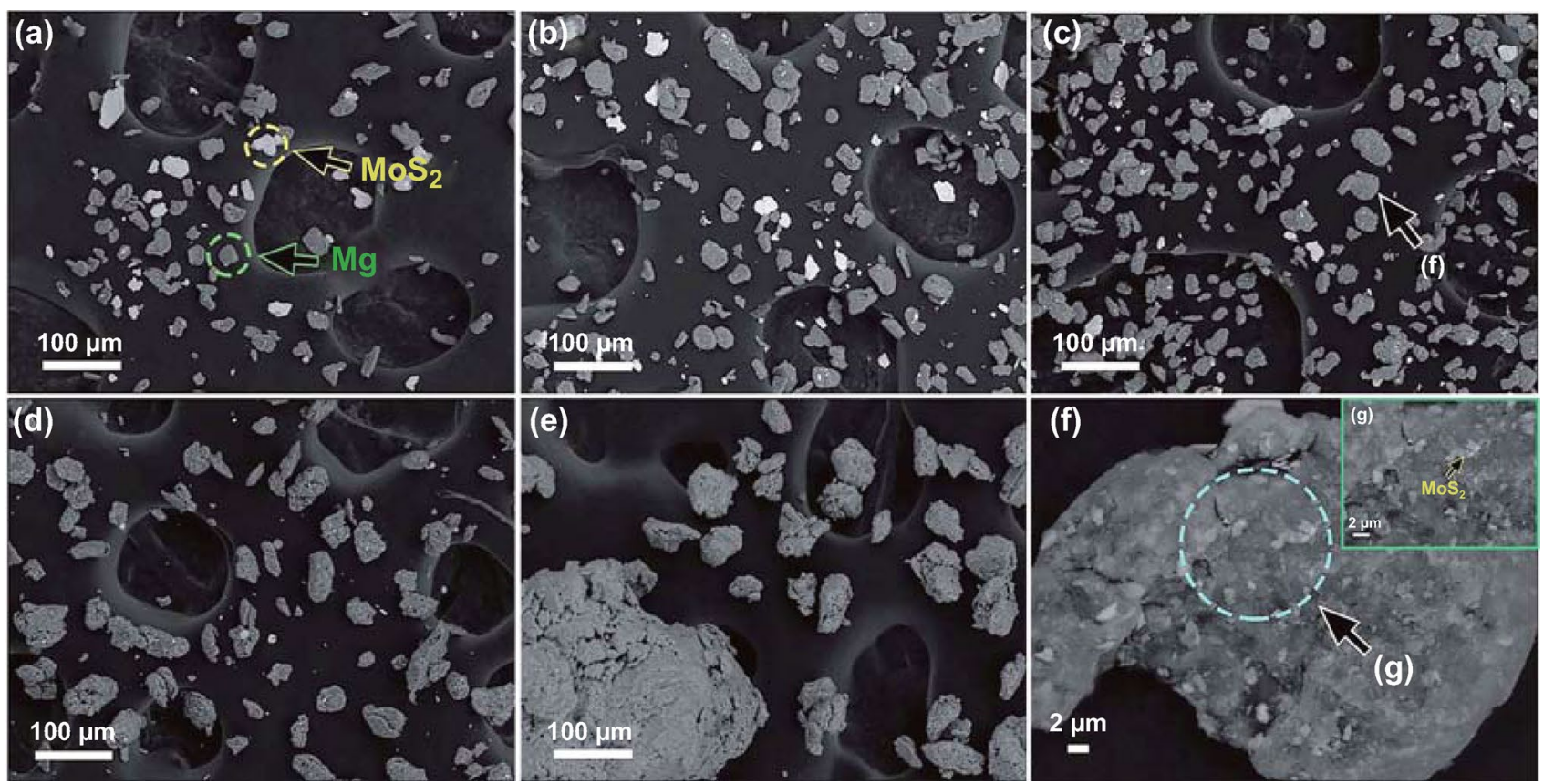

Fig. 6 SEM images of the $\mathrm{Mg}-10 \mathrm{wt} \% \mathrm{MoS}_{2}$ composite milled for various durations: a $0.1 \mathrm{~h}, \mathbf{b} 0.5 \mathrm{~h}, \mathbf{c} 1 \mathrm{~h}$, d $3 \mathrm{~h}$, and e $5 \mathrm{~h}$, f and g highmagnification SEM images showing a small zone of the $\mathrm{Mg}-10 \mathrm{wt} \% \mathrm{MoS}_{2}$ composite milled for $1 \mathrm{~h}$. Reprinted with permission from Ref. [99]. Copyright 2017 Royal Society of Chemistry

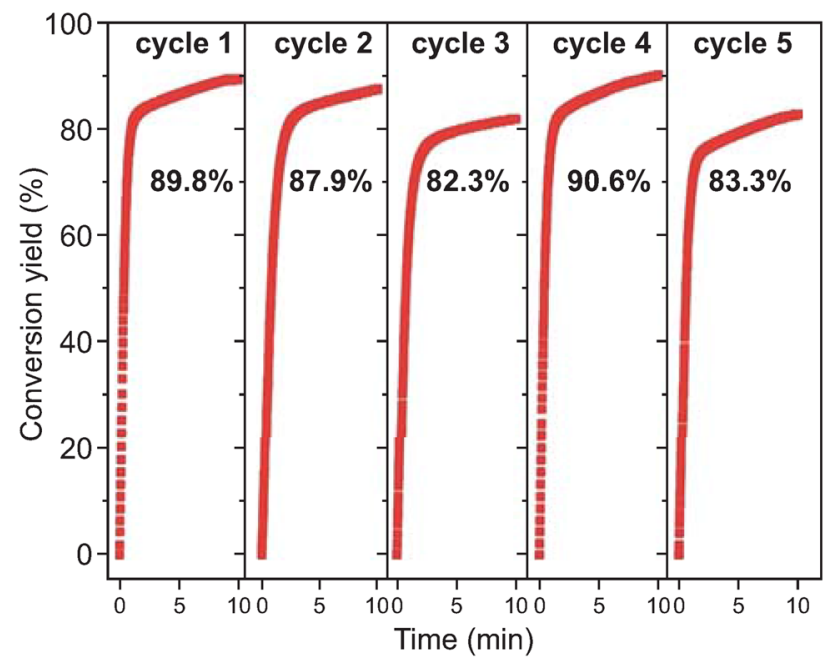

Fig. 7 Cyclic curve of hydrogen evolution via hydrolysis of $\mathrm{Mg}-10$ wt $\%$ retrieved $\mathrm{MoS}_{2}$ milled for $1 \mathrm{~h}$ in seawater. Reprinted with permission from Ref. [99]. Copyright 2017 Royal Society of Chemistry

approximately twice as much as that of $\mathrm{CaMg}_{1.9} \mathrm{Ni}_{0.1}$. In this regard, they doped a small amount of $\mathrm{Ni}$ toward $\mathrm{CaMg}_{2}$ via ball milling [108]. The hydrogen yield of the hydrogenated $\mathrm{CaMg}_{2}-0.1 \mathrm{Ni}$ sample could increase from
853 to $1147 \mathrm{~mL} \mathrm{H}_{2} \mathrm{~g}^{-1}$ in 5 min with hydrogenation durations ranging from 0.5 to $1.5 \mathrm{~h}$. On the other hand, Ouyang et al. [109] found that the hydrolysis properties of Mg can be greatly enhanced with the addition of expanded graphite by plasma-assisted milling. The obtained Mg-graphite composite could release $614.3 \mathrm{~mL} \mathrm{H}_{2} \mathrm{~g}^{-1}$ in 25 min with a hydrolysis conversion rate of $83.5 \%$. They also synthesized refined hydrogenated $\mathrm{MgLi}(\mathrm{H}-\mathrm{MgLi})$ by reactive ball milling [110], producing $15.8 \mathrm{wt} \%$ hydrogen in $5 \mathrm{~min}$. As same as $\mathrm{NaBH}_{4}$, the hydrogen generation behaviors of $\mathrm{Mg}$ would deteriorate markedly followed by decreased temperature. To remove the troublesome freezing issue of the water solution system in low-temperature conditions, Ouyang et al. [111] adopted pure methanol, methanol/water and methanol/ethanol solutions to react with $\mathrm{CaMg}_{2}$ alloy and its hydrides for hydrogen generation. The as-prepared $\mathrm{CaMg}_{2}$ could generate $858 \mathrm{~mL} \mathrm{H}_{2} \mathrm{~g}^{-1}$ within only $3 \mathrm{~min}$ at room temperature, while it reacted vigorously with methanol, as opposed to a low hydrogen yield with ethanol and water (395 and $224 \mathrm{~mL} \mathrm{H}_{2} \mathrm{~g}^{-1}$ within $180 \mathrm{~min}$, respectively). Even at $-20{ }^{\circ} \mathrm{C}$, there was still over $600 \mathrm{~mL} \mathrm{H}_{2} \mathrm{~g}^{-1}$ released at a conversion rate of $70.7 \%$ within 100 min for methanolysis, demonstrating its 
prominent advantage for hydrogen production, especially in winter or subzero areas.

Aqueous solution modification is also an effective strategy to tailor the hydrogen behaviors of Mg-based materials. In real application, large excess of water is required to ensure complete hydrolysis of $\mathrm{Mg}$, resulting in significant capacity loss. The formation of insoluble $\mathrm{Mg}(\mathrm{OH})_{2}$ enables simple separation and repeated using of water, which minimizes the hydrogen capacity loss caused by the excessive water. In this regard, $\mathrm{Li}$ et al. [112] solved the issue by using $\mathrm{MgH}_{2}$ nanoparticles together with the promotion effect of $\mathrm{MgCl}_{2}$ solution. A near-theoretical amount of $\mathrm{H}_{2}\left(1820 \mathrm{~mL} \mathrm{~g}^{-1}\right)$ was released within 20 min in $1 \mathrm{M} \mathrm{MgCl}_{2}$ solution without any pretreatment of the $\mathrm{MgH}_{2}$ nanoparticles $(800 \mathrm{~nm}$ ). By separating $\mathrm{Mg}(\mathrm{OH})_{2}$ through filtration and recycling the $\mathrm{MgCl}_{2}$ solution, the hydrogen capacity of this system may approach the theoretical value of $6.45 \mathrm{wt} \%$ with continuous $\mathrm{MgH}_{2}$ and water feeding. Recently, Tan et al. [113] reported that the hydrolysis performance of $\mathrm{Mg}_{2} \mathrm{Si}$ could be notably improved by using $\mathrm{NH}_{4} \mathrm{~F}$ solution. The fluorine ion was introduced to restrain the release of silanes during the hydrolysis reaction of $\mathrm{Mg}_{2} \mathrm{Si}$. Due to its high chemical affinity to silicon ion, it is possible for $\mathrm{F}^{-}$to break the $\mathrm{Si}-\mathrm{H}$ bond and form $\mathrm{H}_{2}$ and $\mathrm{SiF}_{6}{ }^{2-}$ in aqueous solution. As the concentration of the $\mathrm{NH}_{4} \mathrm{~F}$ solution increased to $13.0 \%$, the hydrogen yield of $\mathrm{Mg}_{2} \mathrm{Si}$ reached the maximum, producing $616 \mathrm{~mL} \mathrm{H}_{2} \mathrm{~g}^{-1}$ in $30 \mathrm{~min}$ at $25^{\circ} \mathrm{C}$. The L.G. Sevastyanova et al. [101] systematically explored the effect of salt solutions and the transition metals on magnesium hydrolysis (Fig. 8) and found (1) the $\mathrm{NH}_{4} \mathrm{Cl}$ solution exhibited the fastest initial reaction rate, but the conversion yield reached the maximum in $\mathrm{NaCl}$ solution, (2) aqueous solutions of alkaline or alkali earth metal chlorides at a salt content over $3 \mathrm{wt} \%$ would effectively improve the hydrolysis performance (the optimal amount being 4-15 wt\%), (3) the transition metals can also cause reduction of the hydrogen yield if it is over $10 \mathrm{wt} \%$. Correspondingly, Table 4 lists the varieties of some $\mathrm{Mg}$-based materials and their hydrolysis properties. Nearly all hydrolysis materials enable the solution concentration being at least $3 \mathrm{wt} \%$ and the amount of oxidation addition not exceeding $10 \mathrm{wt} \%$.

\subsection{Hydrogen Production via Hydrolysis of Al-based Alloys or Its Hydrides}

The distribution of aluminum is more abundant than magnesium, being third only to oxygen and silicon. Aluminum is a safe and cheap metal as well as electrochemically active element; thus, it may be a more appropriate candidate for the process of hydrogen production $[31,128]$. The catholic use of aluminum is for the applications in batteries [129], like the aluminum-air battery that has an aluminum-based anode. While this aluminum-based battery has potential prospect in electric

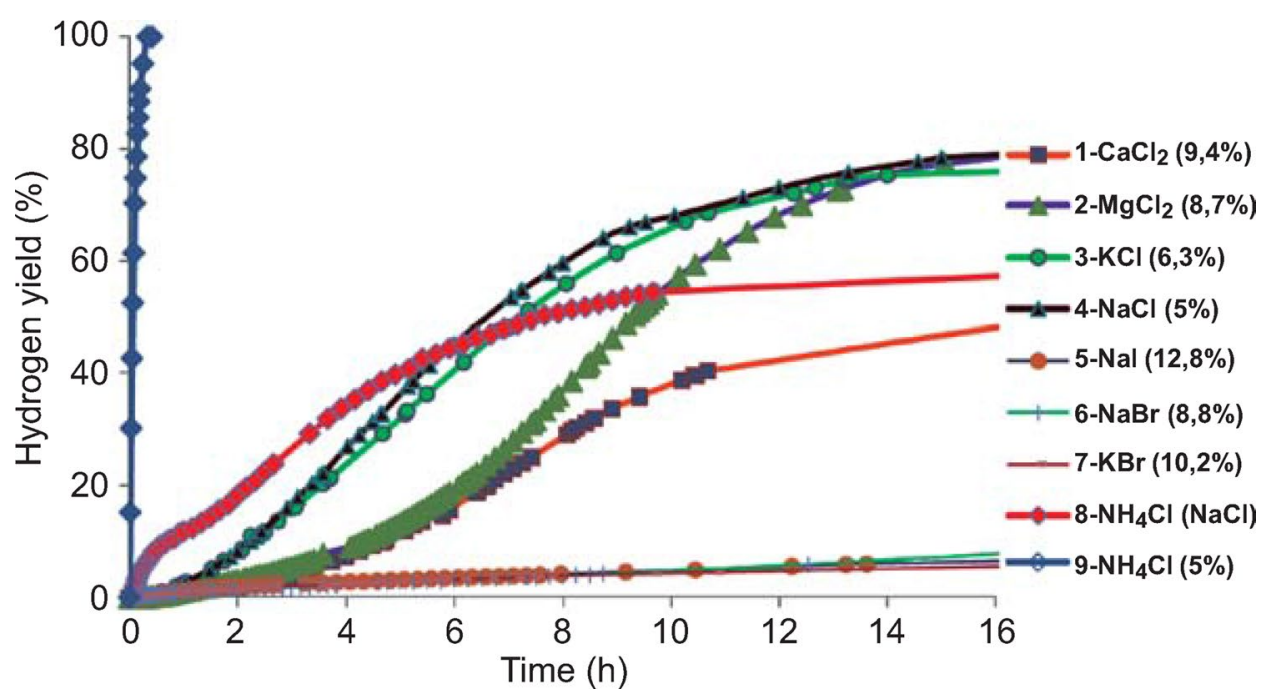

Fig. 8 Yields of hydrogen release due to magnesium powder oxidation in the presence of alkali, alkaline earth and ammonia halides ( $1 \mathrm{~g}$ of $\mathrm{Mg}$

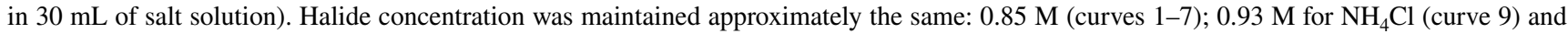
$0.31 \mathrm{M} \mathrm{NH}_{4} \mathrm{Cl}+0.85 \mathrm{M} \mathrm{NaCl}$ (curve 8). Reprinted with permission from Ref. [101]. Copyright 2014 Elsevier 
Table 4 Comparisons of some ball-milling Mg-based materials and their hydrolysis performances

\begin{tabular}{|c|c|c|c|c|c|}
\hline Materials & Solution & Hydrogen yield (\%) & $\begin{array}{l}\mathrm{HGR}\left(\mathrm{mL} \mathrm{H}_{2} /\right. \\
\left.(\mathrm{g} \min )^{-1}\right)\end{array}$ & $\begin{array}{l}\text { Activation energy } \\
\left(\mathrm{kJ} \mathrm{mol}^{-1}\right)\end{array}$ & Refs. \\
\hline $\mathrm{Mg}-10 \mathrm{wt} \% \mathrm{MoS}_{2}$ & $3.5 \% \mathrm{NaCl}$ solution & $90.4 \%$ in $1 \mathrm{~min}$ & - & 12.9 & [100] \\
\hline $\mathrm{Mg}-10 \mathrm{wt} \% \mathrm{MoO}_{3}$ & $3.5 \% \mathrm{NaCl}$ solution & $91.7 \%$ in $10 \mathrm{~min}$ & 2423 & 12.1 & [99] \\
\hline $\mathrm{Mg}-10 \mathrm{wt} \% \mathrm{MoO}_{2}$ & $3.5 \% \mathrm{NaCl}$ solution & $88.0 \%$ in $10 \mathrm{~min}$ & 1933 & 14.3 & [99] \\
\hline $\mathrm{Mg}-10 \mathrm{wt} \% \mathrm{Mo}$ & $3.5 \% \mathrm{NaCl}$ solution & $86.5 \%$ in $10 \mathrm{~min}$ & 751 & 27.6 & [99] \\
\hline $\mathrm{Mg}-10 \mathrm{wt} \% \mathrm{CoCl}_{2}$ & Pure water & $93.4 \%$ in $30 \mathrm{~min}$ & 524 & - & [114] \\
\hline $\mathrm{Mg}-10 \mathrm{wt} \% \mathrm{FeCl}_{3}$ & Pure water & $98 \%$ in $2 \mathrm{~min}$ & 1479.7 & - & [115] \\
\hline $\mathrm{H}-\mathrm{Mg}_{3} \mathrm{La}$ & Water & $88 \%$ in $20 \mathrm{~min}$ & 43.8 & - & [105] \\
\hline $\mathrm{H}-\mathrm{Mg}_{17} \mathrm{La}_{2}$ & Water & $60.1 \%$ in $21 \mathrm{~min}$ & 40.1 & - & [105] \\
\hline $\mathrm{H}-\mathrm{Mg}_{3} \mathrm{CeNi}_{0.1}$ & Pure water & $57.4 \%$ in $10 \mathrm{~min}$ & 276 & - & [97] \\
\hline $\mathrm{H}-\mathrm{CaMg}_{1.9} \mathrm{Ni}_{0.1}$ & Pure water & $94.6 \%$ in $12 \mathrm{~min}$ & - & 32.9 & [107] \\
\hline $\mathrm{H}-\mathrm{MgLi}$ & Pure water & $82 \%$ in $5 \mathrm{~min}$ & - & 10.6 & [110] \\
\hline $\mathrm{H}-\mathrm{MgLi}$ & $1 \mathrm{M} \mathrm{MgCl}_{2}$ solution & $90 \%$ in $30 \mathrm{~min}$ & - & 24.6 & [110] \\
\hline $\mathrm{Mg}-10 \% \mathrm{In}$ & Seawater at $30^{\circ} \mathrm{C}$ & $93 \%$ in $10 \mathrm{~min}$ & 444 & 12.4 & [116] \\
\hline $\mathrm{Mg}-10 \% \mathrm{In}$ & Methanol at $20^{\circ} \mathrm{C}$ & $95 \%$ in $1 \mathrm{~min}$ & 6900 & - & [116] \\
\hline $\mathrm{Mg}-\mathrm{Mg}_{2} \mathrm{Cu}$ eutectic alloy & $3.5 \% \mathrm{NaCl}$ solution & $90 \%$ in $20 \mathrm{~min}$ & - & 36.91 & [117] \\
\hline $\mathrm{Mg}-\mathrm{Mg}_{2} \mathrm{Sn}$ eutectic alloy & $3.5 \% \mathrm{NaCl}$ solution & $90 \%$ in $20 \mathrm{~min}$ & - & 38.19 & [117] \\
\hline Mg-90wt\% NdNiMg 15 & $3.5 \% \mathrm{NaCl}$ solution & $100 \%$ in $15 \mathrm{~min}$ & 60 & - & [118] \\
\hline $\mathrm{Mg}-\mathrm{Mg}_{2} \mathrm{Si}$ & $0.5 \mathrm{M} \mathrm{MgCl}_{2}$ solution & $90 \%$ in $60 \mathrm{~min}$ & - & 9.5 & [93] \\
\hline $\mathrm{Mg}-5 \mathrm{wt} \% \mathrm{G}-5 \mathrm{wt} \% \mathrm{Ni}$ & $3.5 \% \mathrm{NaCl}$ solution & $95 \%$ in $2 \mathrm{~min}$ & - & 14.34 & [119] \\
\hline $\mathrm{Mg}-10 \mathrm{wt} \% \mathrm{Nd}_{2} \mathrm{O}_{5}$ & $3.5 \% \mathrm{NaCl}$ solution & $100 \%$ in $30 \mathrm{~min}$ & - & 31.46 & [119] \\
\hline $30 \mathrm{wt} \% \mathrm{Ca}-\mathrm{Mg}$ hydrides & Deionized water & $69.9 \%$ in $5 \mathrm{~min}$ & - & 8.3 & [120] \\
\hline $\mathrm{Mg}-3 \% \mathrm{~mol} \mathrm{Al}$ & Water & $93.86 \%$ in $60 \mathrm{~min}$ & 455.9 & - & [121] \\
\hline $4 \mathrm{MgH}_{2}-\mathrm{LiNH}_{2}$ & Water & $72.7 \%$ in $50 \mathrm{~min}$ & 887.2 & - & {$[38]$} \\
\hline $\mathrm{MgH}_{2}$ & $4.5 \mathrm{wt} \% \mathrm{NH}_{4} \mathrm{Cl}$ solution & $81 \%$ in $30 \mathrm{~min}$ & - & 30.373 & [98] \\
\hline$(\mathrm{Mg} 10 \mathrm{Ni})_{95} \mathrm{Ce}_{5}$ & Seawater & $87 \%$ in $15 \mathrm{~min}$ & 149.4 & 33.8 & [122] \\
\hline$(\mathrm{Mg} 10 \mathrm{Ni})_{95} \mathrm{Ce}_{5}$-EG-MoS 2 composite & Seawater & $95 \%$ in $1 \mathrm{~min}$ & 773 & 14.5 & [122] \\
\hline$(\mathrm{Mg}-10 \mathrm{Ni})_{85} \mathrm{La}_{15}$ & Distilled water & $12.8 \%$ in $135 \mathrm{~min}$ & 0.4683 & - & [123] \\
\hline$(\mathrm{Mg} 10 \mathrm{Ni})_{95} \mathrm{Ce}_{5}$ & $3.5 \mathrm{wt} \% \mathrm{NaCl}$ solution & $92 \%$ in $200 \mathrm{~min}$ & - & 27.11 & [124] \\
\hline $\mathrm{Mg} 10 \mathrm{Ni}-5 \mathrm{wt} \% \mathrm{EG}-5 \mathrm{wt} \% \mathrm{MoS}_{2}$ & $3.5 \mathrm{wt} \% \mathrm{NaCl}$ solution & $91 \%$ in $5 \mathrm{~min}$ & 148.16 & 9.26 & [125] \\
\hline $\mathrm{Mg}-25 \mathrm{wt} \% \mathrm{Ni}$ & $3.5 \mathrm{wt} \% \mathrm{NaCl}$ solution $\left(48^{\circ} \mathrm{C}\right)$ & $60.3 \%$ in $30 \mathrm{~min}$ & 48.28 & 9.57 & [126] \\
\hline $\mathrm{Mg}-30 \mathrm{wt} \% \mathrm{Ce}$ & $3.5 \mathrm{wt} \% \mathrm{NaCl}$ solution $\left(48^{\circ} \mathrm{C}\right)$ & $85 \%$ in $30 \mathrm{~min}$ & 171.88 & 14.65 & [126] \\
\hline $\mathrm{Mg}-30 \mathrm{wt} \% \mathrm{La}$ & $3.5 \mathrm{wt} \% \mathrm{NaCl}$ solution $\left(48^{\circ} \mathrm{C}\right)$ & $90.2 \%$ in $30 \mathrm{~min}$ & 74.52 & 23.88 & [126] \\
\hline $\mathrm{Mg}_{10} \mathrm{Ni}-5 \mathrm{wt} \% \mathrm{MoS}_{2}$ & $3.5 \mathrm{wt} \% \mathrm{NaCl}$ solution & $67 \%$ in $15 \mathrm{~min}$ & 1480 & 18.79 & [127] \\
\hline
\end{tabular}

vehicles, it is inhibited by the undesirable parasitic corrosion reaction or the formation of a dense oxide layer. But the reaction actually produces hydrogen.

In addition, $\mathrm{OH}^{-}$can dissolve the passive layer and form $\mathrm{AlO}_{2}{ }^{-}$to generate hydrogen even at room temperature. Taking the most commonly used $\mathrm{NaOH}$ solution as an example, the hydrogen generation is proposed as follows [130]:

$2 \mathrm{Al}+6 \mathrm{H}_{2} \mathrm{O}+2 \mathrm{NaOH} \rightarrow 2 \mathrm{NaAl}(\mathrm{OH})_{4}+3 \mathrm{H}_{2}$

$\mathrm{NaAl}(\mathrm{OH})_{4} \rightarrow \mathrm{NaOH}+\mathrm{Al}(\mathrm{OH})_{3}$
$2 \mathrm{Al}+6 \mathrm{H}_{2} \mathrm{O} \rightarrow 2 \mathrm{Al}(\mathrm{OH})_{3}+2 \mathrm{H}_{2}$

$2 \mathrm{Al}+4 \mathrm{H}_{2} \mathrm{O} \rightarrow 2 \mathrm{AlOOH}+3 \mathrm{H}_{2}$

Initially, the hydrogen generation reaction consumes sodium hydroxide, but when the $\mathrm{NaAl}(\mathrm{OH})_{4}$ concentration exceeds the saturation limit, it leads to the $\mathrm{NaOH}$ regeneration process accompanying aluminum hydroxide formation. Therefore, only water is consumed during the whole hydrogen supply as shown by the reactions ( 4 and 
5), and the hydrolysis by-products are the non-polluting bayerite $\left(\mathrm{Al}(\mathrm{OH})_{3}\right)$ and boehmite $(\mathrm{AlOOH})[2,131,132]$. Though the addition of $\mathrm{OH}^{-}$is considered as the simplest and the most effective approach for promoting the Al/ $\mathrm{H}_{2} \mathrm{O}$ reaction [133], the use of an aqueous $\mathrm{NaOH}$ solution causes corrosion of system apparatus. Therefore, novel technologies that enable a combination of a minimized quantity of $\mathrm{NaOH}$ and rapid $\mathrm{H}_{2}$ generation kinetics are highly desirable. Wang et al. [134, 135] found that a combined usage of sodium hydroxide $(\mathrm{NaOH})$ and sodium stannate $\left(\mathrm{Na}_{2} \mathrm{SnO}_{3}\right)$ can simultaneously address the $\mathrm{Al} /$ $\mathrm{H}_{2} \mathrm{O}$ reaction kinetics and alkali corrosion problems. The addition of a small amount of $\mathrm{Na}_{2} \mathrm{SnO}_{3}$ causes a remarkable decrease of $\mathrm{NaOH}$ concentration without compromising the hydrogen generation performance of the system. In comparison with the traditional $\mathrm{Al} / \mathrm{H}_{2} \mathrm{O}$ system using aqueous $\mathrm{NaOH}$ solution, the new system exhibits a series of advantages in hydrogen generation performance, manipulability and adaptability; all are relevant to the development of practical aluminum-based hydrogen generation systems for mobile or portable applications. Notably, aluminum can be regenerated from the by-products by mature industrial technologies, the Bayer process [136] from bauxite ore $(\mathrm{AlOOH})$ and the Hall-H'eroult process [137] from alumina.

Since Belitskus [130] first proposed the Al-water reaction to provide hydrogen in the 1970s, crucial efforts have been put into action to overcome the hydrolysis obstacle caused by the formation of the $\mathrm{Al}_{2} \mathrm{O}_{3}$ layer. Ball milling, as a frequently used method for increasing the hydrolysis performance of Mg-based materials, has proved to be effective for Al-based materials [138-142]. Yan et al. [140] milled an Al-10 mol\% LiH-10 mol\% KCl mixture for $10 \mathrm{~h}$ and obtained a hydrogen yield of $97.1 \%$ in $10 \mathrm{~min}$ at $60{ }^{\circ} \mathrm{C}$. The effects of metal chlorides to aluminum were similar to magnesium in hydrolysis. Firstly, chlorides can decrease the grain size during ball milling, and secondly, chlorides can also raise galvanic corrosion of magnesium or aluminum. Thirdly, $\mathrm{Cl}^{-}$could damage the $\mathrm{Mg}(\mathrm{OH})_{2}$ or $\mathrm{Al}(\mathrm{OH})_{3}$ layer. Except mechanical activation by ball milling, torsional pressure and ultrasonic assistance, chemical activation of aluminum, such as by alloying, is also applicable. Originally, mercury was utilized for chemical activation of aluminum [143]. While mercury is a toxic substance and is not recommended for use in large scale, the new method of alloying to activate aluminum for aluminum-water reaction is sought after [144-147].

It has been confirmed that the hydrolysis properties have been enormously boosted up by alloying low melting point metals (LMPM) such as Ga, In, Sn and Zn with Al. Bulychev et al. [144] investigated the hydrolysis properties of aluminum alloy containing different accounts of LMPM. They found that the hydrogen supply virtually did not proceed without the presence of gallium, and the absence of indium in the alloy also led to a sharp decrease in the hydrolytic ability. But this alloy showed a terrible stability even stored under an inert atmosphere or in vacuum. They believed that this might be related to the presence of dispersed solid phases and a liquid phase (eutectic) distributed over the grain boundary space (Fig. 9). Parmuzinaa [145] held a point of view that the liquid eutectics based on gallium brought about eutectic penetration into aluminum grain boundaries, which destructed the inter-crystal contacts and resulted in the formation of aluminum monocrystal powders covered by eutectic thin film. Dong et al. [148] demonstrated that the presence of a liquid phase in the $\mathrm{Al}-\mathrm{Ga}$ and $\mathrm{Al}-\mathrm{Ga}-\mathrm{In}-\mathrm{Sn}$ alloys was decisive for the alloys to react with water and produce $\mathrm{H}_{2}$ with an average yield of $83.8 \%$ in all 80 trials. The reaction temperature correlated well with the reported Al-Ga binary eutectic melting point of $26.6{ }^{\circ} \mathrm{C}$ and Ga-In-Sn ternary eutectic melting point of $10.7{ }^{\circ} \mathrm{C}$. When they changed the reaction temperature to make the alloys completely solid without liquid phase distribution, no hydrogen was produced. Interestingly, in many experiments, it was found that at $20-30{ }^{\circ} \mathrm{C}$, hydrogen generation from $\mathrm{Al}-\mathrm{Ga}$ alloys stopped after only a certain extent [147, 149-153], but the reaction would resume if the system temperature was raised to resuscitate the liquid eutectic phase.

However, compared to the binary and ternary systems, the activity of the quaternary Al-Ga-In-Sn alloy was greatly improved and it could be fully reactive even at room temperature, indicating that the presence of a liquid eutectic phase in the Al-based alloy was essential. Liquid $\operatorname{In}_{3} \mathrm{Sn}$ and $\mathrm{InSn}_{4}$ were indeed observed in the Al-Ga-In-Sn quaternary system [154]. Qian Gao et al. [150] compared the hydrolysis properties of $\mathrm{Al}-\mathrm{Ga}-\mathrm{InSn}_{4}$ and $\mathrm{Al}-\mathrm{Ga}-\mathrm{In}_{3} \mathrm{Sn}$ alloys (Fig. 10). They concluded that the eutectic reaction of $\mathrm{Al}$ with $\mathrm{InSn}_{4}$ was crucial, and $\mathrm{Al}$ could transfer from Al grains to intermetallic compounds to react with water continuously. Recently, Lu et al. [155] investigated the hydrolysis performance and activation mechanism of $\mathrm{Al}$ 

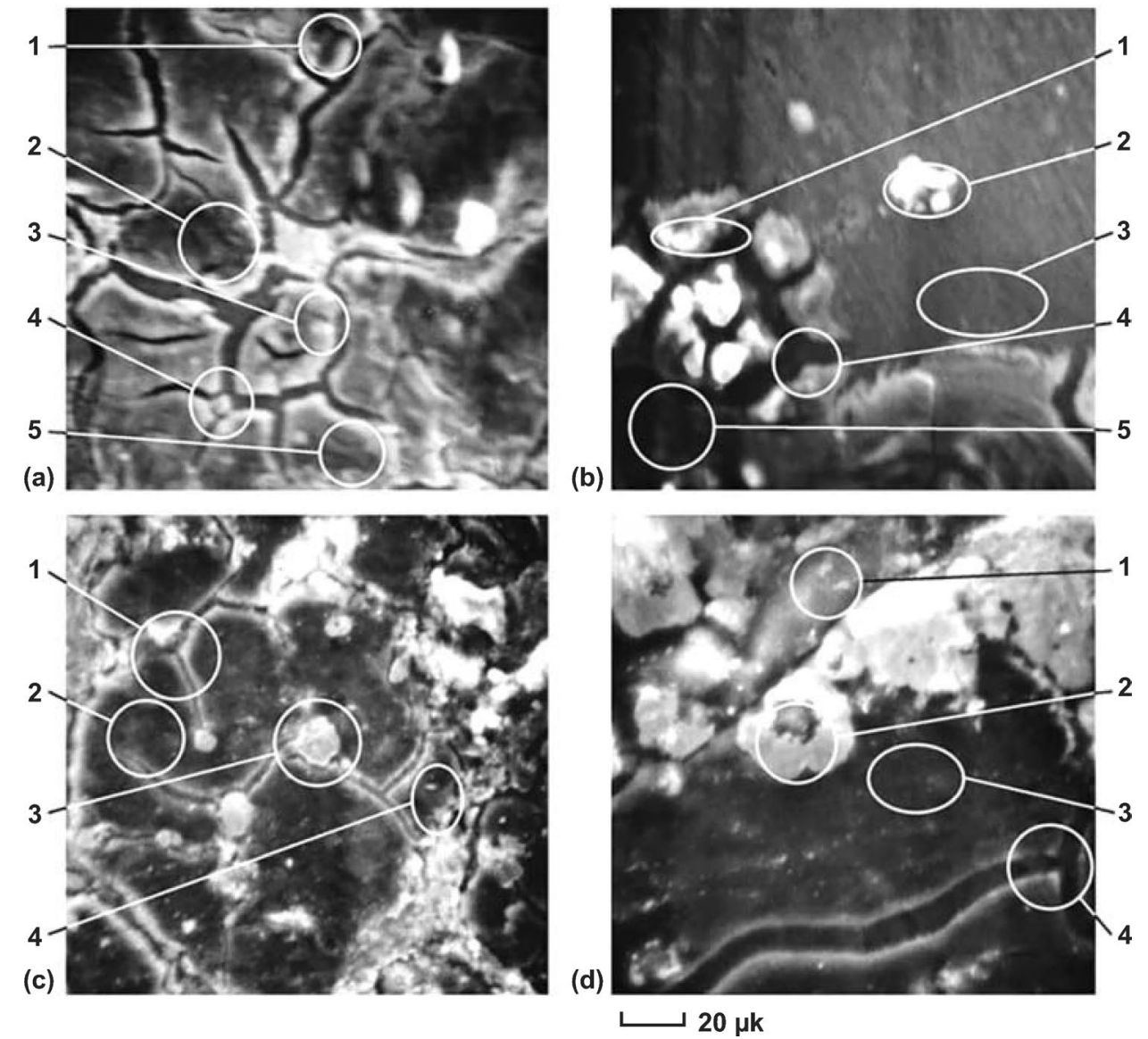

Fig. 9 SEM images of multicomponent aluminum alloy (Ga:In:Sn:Zn:Al=5.3:2.0:5.4:7.3:80.0) sections $(\times 800)$. A After preparation, B after annealing at $450{ }^{\circ} \mathbf{C}$ for $20 \mathrm{~h}$. $\mathbf{C}$ and $\mathbf{D}$ after storing as-cast and annealed alloys for 1 month. Reprinted with permission from Ref. [144]. Copyright 2005 Elsevier
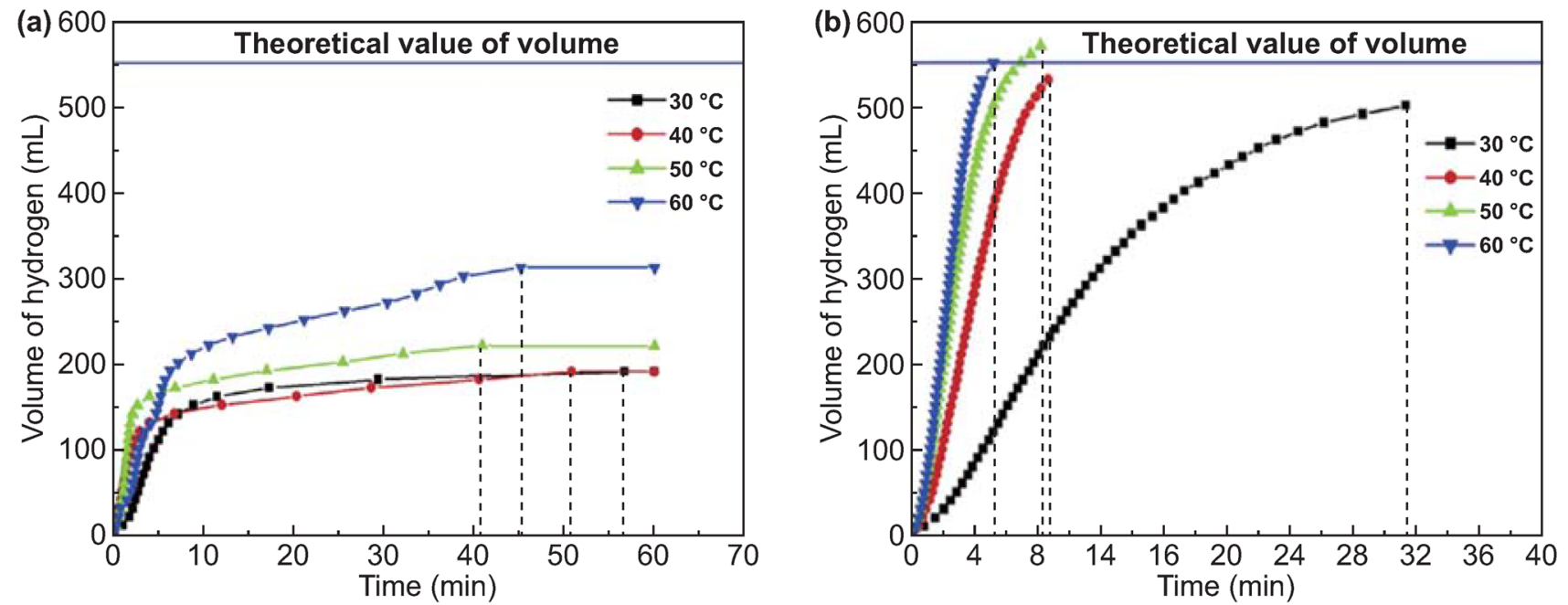

Fig. 10 Water temperature effect on hydrogen generation of $\mathrm{Al}-\mathrm{Ga}-\mathrm{InSn}_{4}$ alloy and $\mathrm{Al}-\mathrm{Ga}-\mathrm{In}_{3} \mathrm{Sn}$ alloy $(0.5 \mathrm{~g}$ alloy ingot in $100 \mathrm{~mL}$ water), a $\mathrm{Al}-\mathrm{Ga}-\mathrm{InSn}_{4}$ alloy and b Al-Ga-In 3 Sn alloy. Reprinted with permission from Ref. [150]. Copyright 2015 Elsevier 

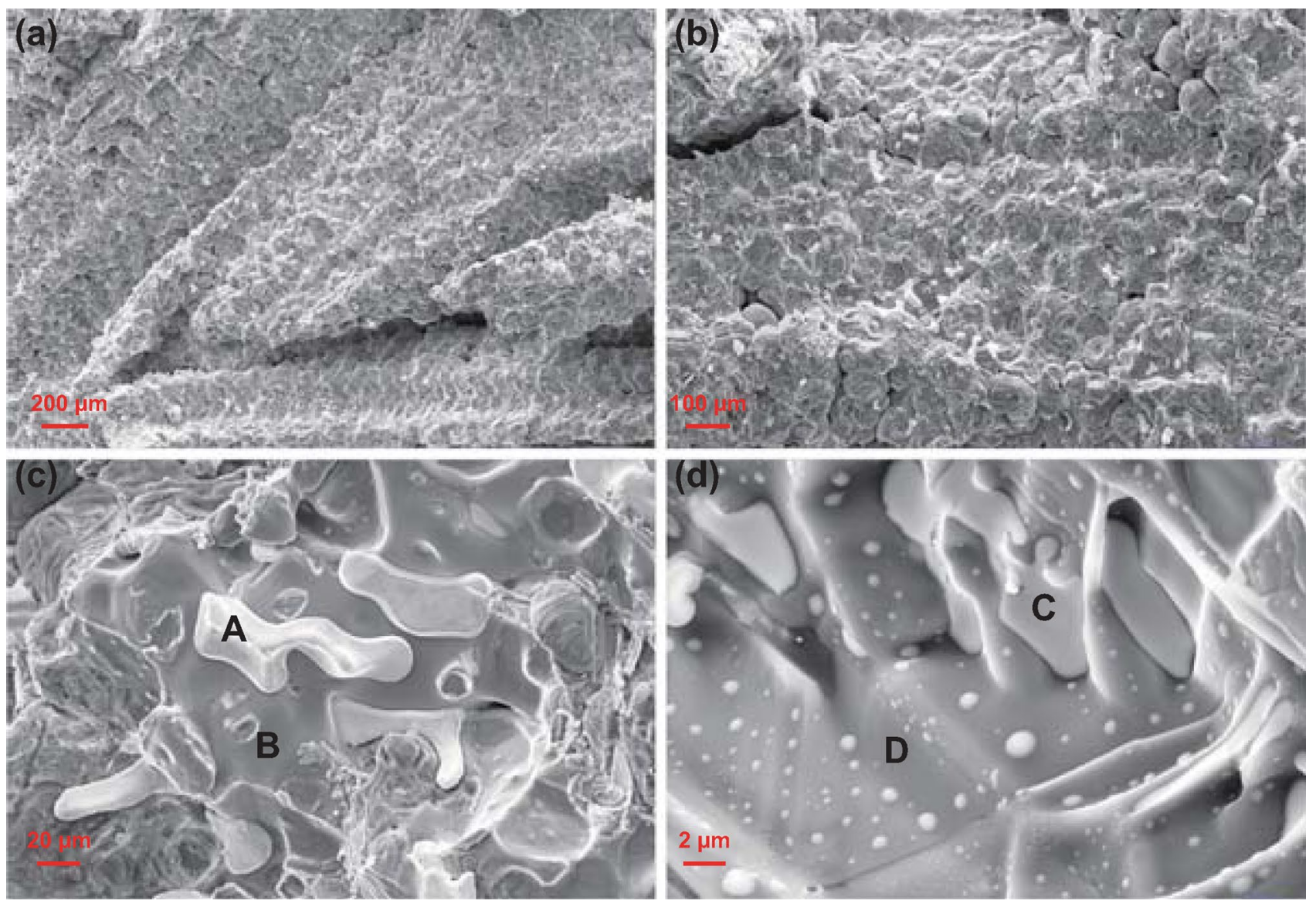

Fig. 11 SEM images of fracture surfaces of $\mathrm{Al} 85 \mathrm{wt} \%-\mathrm{Ga}_{68.5} \mathrm{In}_{21.5} \mathrm{Sn}_{10}$ alloy ingots, $\mathbf{a}, \mathbf{b}$ images of the quaternary alloy, $\mathbf{c}$ enlarged image of intermetallic compounds, and $\mathbf{d}$ image of the LMPA at the grain boundary. Reprinted with permission from Ref. [155]. Copyright 2019 Elsevier

$85 \mathrm{wt} \%-\mathrm{Ga}_{68.5} \mathrm{In}_{21.5} \mathrm{Sn}_{10}$ alloy (Fig. 11). Combined with EDX analysis, the marked regions in the SEM images shown in Fig. $11 \mathrm{c}, \mathrm{d}$ could be identified as $\mathrm{In}_{3} \mathrm{Sn}$ phase (A), Al-Ga solid solution (matrix B), and C GaInSn liquid alloy (GIS) (C) and Al-Ga solid solution (matrix D). Especially, they emphasized the promotion of Al-water reaction with respect to the presence of low-melting eutectic liquid alloy GIS [156] and the $\mathrm{In}_{3} \mathrm{Sn}$ phase. The Al-water reaction can be summarized in two steps. Firstly, a certain amount of $\mathrm{Al}$ atoms, which are solvated in the GIS and $\mathrm{In}_{3} \mathrm{Sn}$ phases, are active and could react with the water freely. Secondly, the local temperature of the reaction site evidently increases due to a highly exothermic reaction, which can further promote the transportation of $\mathrm{Al}$ atoms to the interface and then react with water continuously.

It has been proven that alloying $\mathrm{Al}$ with low melting point metals is an effective approach to inhibit the formation of a coherent passivation layer and promote the hydrolysis kinetics. Liu et al. [153] tested Al on four different liquid alloys to produce hydrogen. It was found that aluminum completely dissolved in liquid $\mathrm{GaIn}_{10}$ in $4 \mathrm{~min}$, and the liquid metal surface remained shiny, meaning that $\mathrm{GaIn}_{10}$ was stable during entire reaction process (Fig. 12). They designed pure Ga as a reactor and successively inlaid $\mathrm{Al}$ into it, and the process still achieved a great conversion yield after 5 times cycle without any dead-weight issues involved in system. Table 5 summarizes the varieties of some Al-based materials and their hydrolysis properties.

\subsection{Hydrogen Production via Hydrolysis of Al-based Alloys or Its Hydrides}

Hydrolysis of metals or metal hydrides is a highly exothermic reaction; full hydrolysis of $1 \mathrm{~mol}$ aluminum generates 
(a)
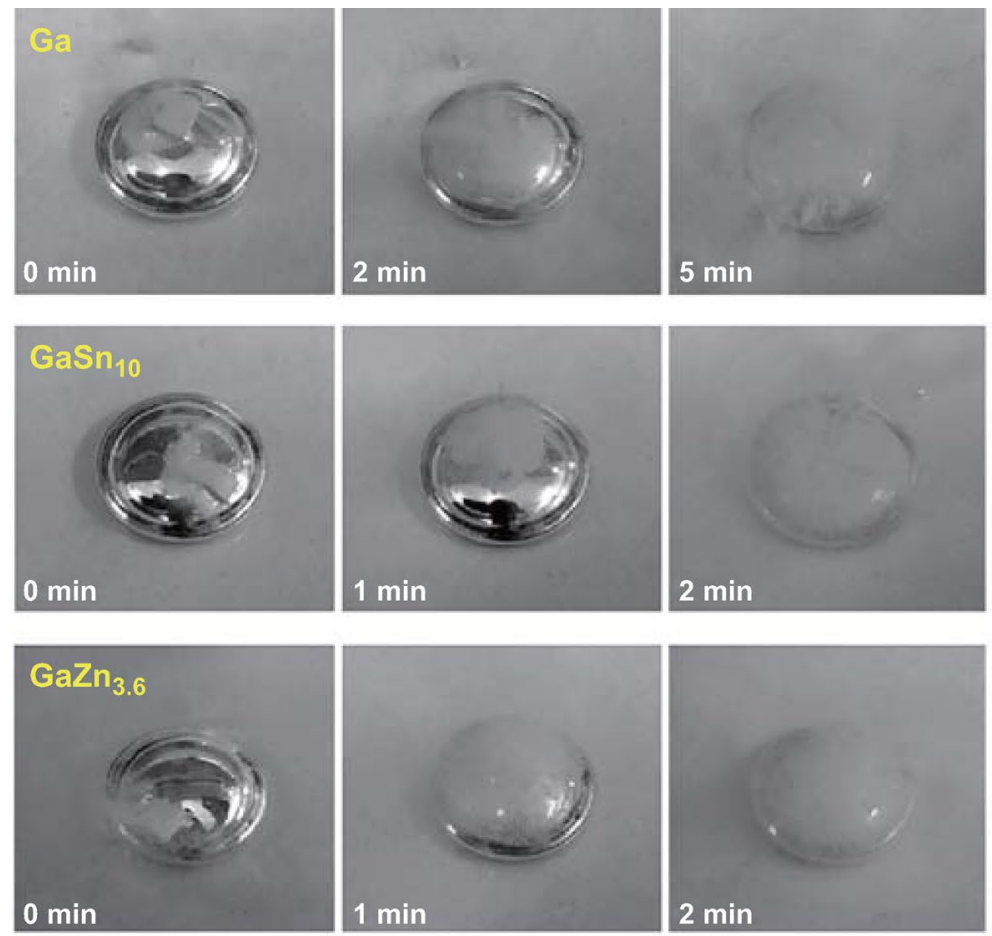

(c)
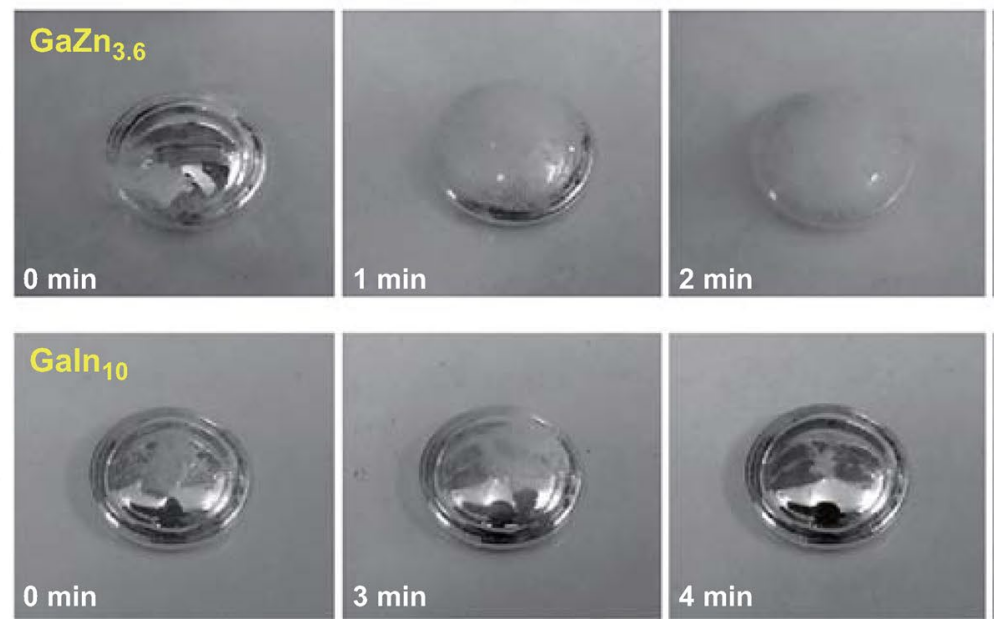
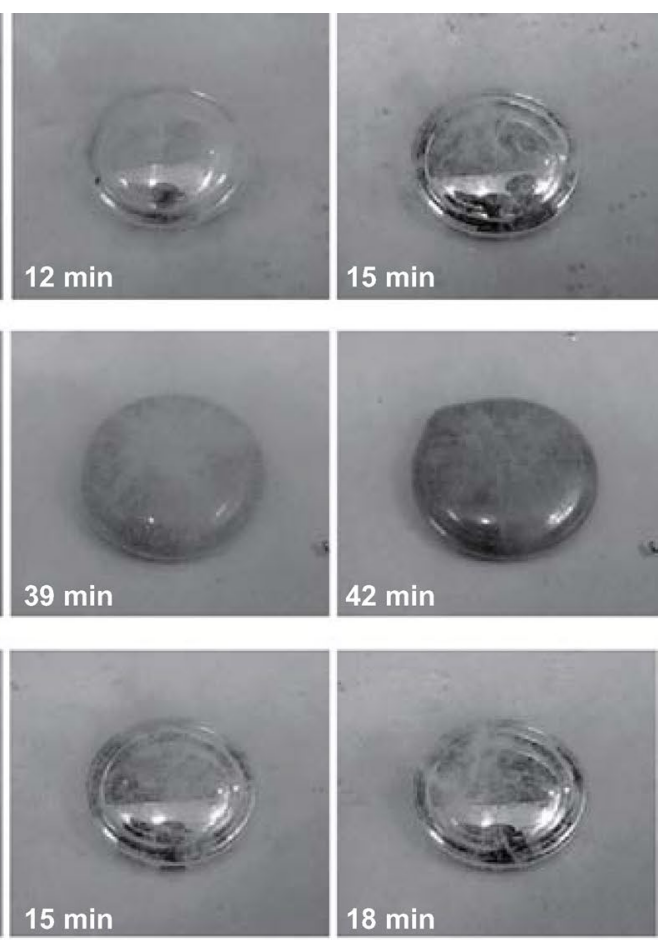

$18 \mathrm{~min}$
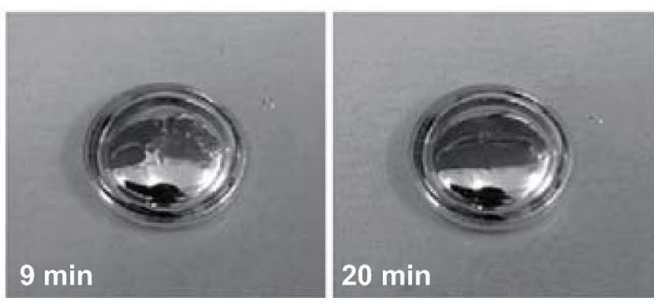

Fig. 12 Surface morphology comparisons among different liquid metals in aluminum-water reaction. a Ga. b GaSn $\mathrm{G}_{10}$ c GaZn ${ }_{3.6}$. d GaIn . $_{10}$. Reprinted with permission from Ref. [153]. Copyright 2016 Elsevier

$437 \mathrm{~kJ}$ heat and $1.5 \mathrm{~mol}$ hydrogen. An amount of $363 \mathrm{~kJ}$ energy can be produced unambiguously from this $1.5 \mathrm{~mol}$ hydrogen if it can be thoroughly utilized. Similarly, the hydrolysis of $1 \mathrm{~mol}$ magnesium generates $354 \mathrm{~kJ}$ heat and 1 mol hydrogen. While the exothermicity is huge during the metal-water hydrolysis, there were only few efforts that tried to transform the thermal energy into other forms of useful energy. In particular, Zhong et al. [180] calculated the energy efficiencies in the hydrolysis cycles of $\mathrm{MgH}_{2}, \mathrm{H}-\mathrm{Mg}_{3} \mathrm{La}$ and $\mathrm{H}-\mathrm{La}_{2} \mathrm{Mg}_{17}$. The maximum energy efficiencies of $\mathrm{MgH}_{2}, \mathrm{H}-\mathrm{Mg}_{3} \mathrm{La}$, and $\mathrm{H}-\mathrm{La}_{2} \mathrm{Mg}_{17}$ were estimated to be $45.3 \%, 40.1 \%$, and $41.1 \%$, respectively, meaning roughly half of the energy released by the exothermic reaction was collected. Xiao et al. [181] firstly conceived and designed the Al-based hydrolysis battery, where the hydrolysis of Al was decoupled into a battery by pairing an Al foil with a hydrogen-storage electrode. In the hydrolysis battery, $8-15 \%$ of the hydrolysis heat was converted into usable electrical energy, leading to much higher energy efficiency compared to that of direct hydrolysis- $\mathrm{H}_{2}$ fuel cell approach. The schematic illustration of the hydrolysis battery is shown in Fig. 13, where the hydrolysis reaction of $\mathrm{Al}$ is a redox reaction. Thus, $\mathrm{Al}$ foil and a Pd-capped $\mathrm{YH}_{2}$ thin film were used as the anode and the cathode, respectively. As the hydrolysis battery was activated, the $\mathrm{YH}_{2}$-Pd electrode would convert into $\mathrm{YH}_{2+\mathrm{x}}$ phase $(\mathrm{x} \approx 1$, the hydrogenated state), attaining the electrons flowed from Al. Desirably, the higher utilization of hydrolyzed thermal energy and more efficient kinetics controllability require further investigation. 
Table 5 Comparisons of some Al-based materials and their hydrolysis performances

\begin{tabular}{|c|c|c|c|c|c|}
\hline Materials & Solution & Hydrogen yield (\%) & $\begin{array}{l}\mathrm{mHGR}(\mathrm{mL} \\
\mathrm{H}_{2}(\mathrm{~g} \min ) \\
-1)\end{array}$ & $\begin{array}{l}\text { Activation } \\
\text { energy }(\mathrm{kJ} \\
\left.\mathrm{mol}^{-1}\right)\end{array}$ & Refs. \\
\hline $\mathrm{Al}-15 \mathrm{wt} \% \mathrm{Ga}_{67} \mathrm{In}_{20.5} \mathrm{Sn}_{12.5}$ & Tap water & $87.79 \%$ in $2 \mathrm{~h}$ & - & - & {$[155]$} \\
\hline Al-10 wt $\% \mathrm{Ga}_{68} \mathrm{In}_{21} \mathrm{Sn}_{0.75} \mathrm{Bi}_{0.75} \mathrm{Zn}_{0.75}$ & Tap water & $99.55 \%$ in $6 \mathrm{~h}$ & - & - & {$[155]$} \\
\hline Al-10wt $\% \mathrm{Sn}-5 \mathrm{wt} \% \mathrm{Zn}-5 \mathrm{wt} \% \mathrm{MgH}_{2}$ & Pure water & $72.6 \%$ & 159.6 & 17.57 & {$[157]$} \\
\hline $\mathrm{Al}-10 \mathrm{~mol} \% \mathrm{LiH}-10 \mathrm{~mol} \% \mathrm{KCl}$ & Water & $97.1 \%$ & 1221.1 & - & {$[157]$} \\
\hline $\begin{array}{l}\mathrm{Al} / \mathrm{Ni} / n \mathrm{NaCl}(\mathrm{Ni} / \mathrm{Al}=2: 10, n=24 \mathrm{wt} \%) \mathrm{mix}- \\
\text { tures }\end{array}$ & Distilled water & $92.9 \%$ & 3.1 & 54 & {$[158]$} \\
\hline Al-16 wt\% Bi alloy & $1 \mathrm{M} \mathrm{NaCl}$ solution & $92.75 \%$ & 92 & - & {$[159]$} \\
\hline Aluminum with zinc amalgam activation & Water & - & - & 43.4 & [143] \\
\hline $\mathrm{Al}-5 \mathrm{wt} \% \mathrm{In}-3 \mathrm{wt} \% \mathrm{Zn}-2 \mathrm{wt} \% \mathrm{NaCl}$ mixture & Water & $82.9 \%$ & 250 & - & {$[160]$} \\
\hline Al-Ga-OMC nanocomposite & Pure water & $100 \%$ & 112 & - & {$[161]$} \\
\hline 50 wt $\%$ Al-34 wt $\%$ Ga-11 wt $\%$ In-5 wt $\%$ Sn & Distilled water & $\sim 83.8 \%$ & 78 & 43.8 & {$[162]$} \\
\hline $\mathrm{Al}-\mathrm{Ga}-\mathrm{In}-\mathrm{Sn}$ alloy & Water & - & $\sim 700$ & $53 \pm 4$ & [149] \\
\hline Al-Ga-In-Sn-Fe(92.5:3.8:1.5:0.7:1.5) alloy & Distilled water & $100 \%$ & 120 & - & {$[152]$} \\
\hline $1 \mathrm{ml}$ liquid $\mathrm{Ga}+50 \mathrm{mg}$ aluminum block & $\mathrm{NaOH}$ solution & $\sim 88.7$ & $\sim 37.5$ & - & {$[153]$} \\
\hline Al-3wt $\% \mathrm{Ga}-3 \mathrm{wt} \% \mathrm{In}$ & & - & 180 & - & {$[154]$} \\
\hline Al-3wt $\%$ Ga-3wt $\%$ In- -5 wt $\%$ Sn & Water & $99 \%$ & 1080 & - & {$[154]$} \\
\hline Al-12Bi-7Zn (wt.\%) powder & $\mathrm{NaCl}$ solution & $98 \%$ & - & - & {$[163]$} \\
\hline $\mathrm{Al}$ alloy $/ \mathrm{NaCl} / 1 \mathrm{~g}-\mathrm{g}-\mathrm{C}_{3} \mathrm{~N}_{4}$ & Tap water & $94 \%$ & 280 & 21.28 & {$[164]$} \\
\hline Al-10 wt $\%$ Li-5 wt $\%$ Sn & Water & $100 \%$ & 44.3 & - & {$[165]$} \\
\hline incomplete core/shell structures $\mathrm{Al}-20 \mathrm{wt} \% \mathrm{Bi}$ & Distilled water & $83 \%$ & - & - & {$[166]$} \\
\hline $\mathrm{Al}-7.5 \% \mathrm{Bi}-2.5 \%$ In composite & Pure water & $95.5 \%$ & 194 & - & {$[167]$} \\
\hline $\mathrm{Al}-\mathrm{Ga}-\mathrm{In}-\mathrm{Sn}$ alloy & Water $\left(50^{\circ} \mathrm{C}\right)$ & $95 \%$ & - & - & [168] \\
\hline $\begin{array}{l}\mathrm{Al}-30 \mathrm{wt} \% \mathrm{Bi}-10 \mathrm{wt} \% \mathrm{C} \text { composites synthesized } \\
\text { by high-pressure torsion }\end{array}$ & Pure water $\left(60^{\circ} \mathrm{C}\right)$ & $100 \%$ & 270 & - & [169] \\
\hline $\mathrm{Al}-15 \mathrm{wt} \% \mathrm{NaMgH}_{3}-\mathrm{Bi}^{-\mathrm{Li}_{3} \mathrm{AlH}_{6}}$ & Distilled water & $100 \%$ & 1464 & 21.3 & {$[170]$} \\
\hline Al-10 wt $\% \mathrm{BiOCl}-5 \mathrm{wt} \% \mathrm{LiH}$ & Distilled water & $94.9 \%$ & 3178.5 & 26.9 & {$[171]$} \\
\hline$\left(\mathrm{Al}_{2} \mathrm{Ga}\right)-8 \mathrm{wt} \% \mathrm{In}$ & Distilled water & $70 \%$ & 7.78 & - & {$[172]$} \\
\hline $\begin{array}{l}\mathrm{Al}-1.0 \mathrm{wt} \% \mathrm{Ga}-1.5 \mathrm{wt} \% \mathrm{In}-3.0 \mathrm{wt} \% \mathrm{SnCl}_{2}- \\
\quad 1.0 \mathrm{wt} \% \mathrm{Bi}_{2} \mathrm{O}_{3} \text { composite }\end{array}$ & Tap water & $92 \%$ & 1030.5 & 20.08 & {$[173]$} \\
\hline $\mathrm{Al}-\mathrm{Ga}-\mathrm{In}_{3} \mathrm{Sn}-\mathrm{Zn}$ alloy & Deionized water & $\sim 95 \%$ & 150 & 59 & {$[174]$} \\
\hline $\mathrm{Al}-\mathrm{Cu}-\mathrm{Ga}-\mathrm{In}-\mathrm{Sn}$ alloy & Distilled water & $82.9 \%\left(50^{\circ} \mathrm{C}\right)$ & 135 & - & {$[175]$} \\
\hline $92 \mathrm{Al}-2 \mathrm{Mg}-3.8 \mathrm{Ga}-1.5 \mathrm{In}-0.7 \mathrm{Sn}$ & Distilled water & $91 \%$ & 14.8 & - & {$[176,177]$} \\
\hline $\mathrm{MHA}-2 \% \mathrm{NaOH}$ & $0.5 \mathrm{M} \mathrm{NaOH}$ solution $\left(55^{\circ} \mathrm{C}\right)$ & $97.5 \%$ & 421 & 29.3 & {$[177]$} \\
\hline $\mathrm{Al}$ with Graphite mixed $\mathrm{Al}(\mathrm{OH})_{3}(\mathrm{G}-2)$ catalyst & Distilled water & $100 \%$ & 68 & 27.94 & {$[178]$} \\
\hline $\mathrm{Al} / \mathrm{Ni}_{0 \cdot 1} / \mathrm{Cu}_{0 \cdot 1} / \mathrm{H}_{2} \mathrm{O}$ & Deionized water & 70.6 & 96 & - & [179] \\
\hline
\end{tabular}

\section{Recent Advances in Regeneration Process of Borohydrides from Hydrolysis By-products}

It has been demonstrated that hydrogen supply from $\mathrm{NaBH}_{4}$ hydrolysis is a potential system for hydrogen generation. However, the hydrolysis reactions are plagued by irreversibility, and the resulting high-cost strikingly restrains the large-scale practical applications of these hydrolytic materials. Recently, Ouyang et al. developed a facile and economical method for $\mathrm{NaBH}_{4}$ regeneration by recycling its real-time hydrolysis products $\left(\mathrm{NaBO}_{2} \cdot 2 \mathrm{H}_{2} \mathrm{O}\right.$ and $\left.\mathrm{NaBO}_{2} \cdot 4 \mathrm{H}_{2} \mathrm{O}\right)$ for the first time without hydrides input [182, 183]. This may provide important insights for retrieving other hydrogen supply irreversible systems with high efficiency, such as $\mathrm{LiBH}_{4}$ or $\mathrm{LiAlH}_{4}$ production. 


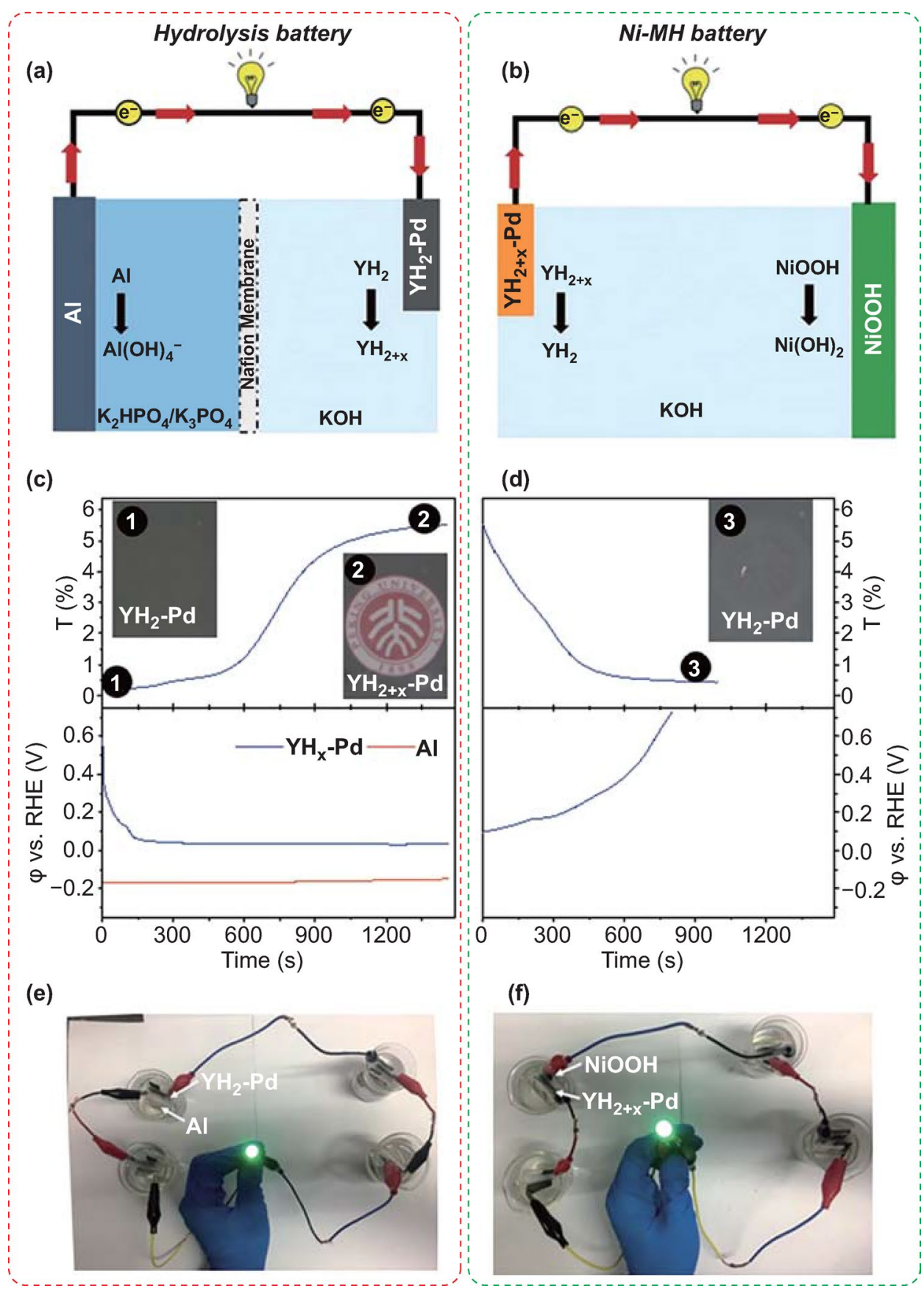

Fig. 13 Schematic illustration of the Al hydrolysis battery a and the conventional Ni-MH battery $\mathbf{b}$ and their operation principle. Synchronized optical transmittance at $500 \mathrm{~nm}$ (the upper panel) and potential profiles (the lower panel) of the $\mathrm{YH}_{\mathrm{x}}$-Pd electrode during galvanostatic process in the hydrolysis battery $\mathbf{c}$ and Ni-MH battery $\mathbf{d}$. The current density is 0.2 and $0.05 \mathrm{~mA} \mathrm{~cm}^{-2}$ for the Al hydrolysis battery and the Ni-MH battery, respectively. The potential profile of the $\mathrm{Al}$ electrode during the operation of the hydrolysis battery is also shown. Inset: photographs of the $\mathrm{YH}_{\mathrm{x}}-\mathrm{Pd}$ electrode at different stages as indicated by the corresponding number in the transmittance curve. Photographs of lighting the LED by the $\mathrm{Al}$ hydrolysis battery e and the MH-Ni battery (f). The electrolyte of hydrolysis battery and Ni-MH battery in e, $\mathbf{f}$ is $1 \mathrm{M} \mathrm{KOH}$. Reprinted with permission from Ref. [181]. Copyright 2018 Wiley Online Library

Recently, more attentions were shifted to the preparation and regeneration of $\mathrm{NaBH}_{4}$ for achieving its large-scale practical applications. In the industry of chemical production,
$\mathrm{NaBH}_{4}$ is usually synthesized by the Brown-Schlesinger process [184] and the Bayer process [185]. The synthesis 
reactions of Schlesinger and Bayer methods are given as follows:

$4 \mathrm{NaH}+\mathrm{B}\left(\mathrm{OCH}_{3}\right)_{3} \rightarrow \mathrm{NaBH}_{4}+3 \mathrm{NaOCH}_{3}\left(225 \sim 275^{\circ} \mathrm{C}\right)$

$$
\begin{aligned}
& \mathrm{Na}_{2} \mathrm{~B}_{4} \mathrm{O}_{7}+16 \mathrm{Na}+8 \mathrm{H}_{2}+7 \mathrm{SiO}_{2} \\
& \rightarrow \mathrm{NaBH}_{4}+7 \mathrm{Na}_{2} \mathrm{SiO}_{3}\left(450 \sim 500^{\circ} \mathrm{C}\right)
\end{aligned}
$$

Though the above technologies are mature, they are unsuitable for $\mathrm{NaBH}_{4}$ hydrolysis applications because of the fancy raw materials ( $\mathrm{Na}$ or $\mathrm{NaH}$ ) and high-energy consumption processes. Thus, suitable methods for $\mathrm{NaBH}_{4}$ synthesis have been developed with low-cost raw materials instead of sodium or its hydride. $\mathrm{MgH}_{2}$ was used to react with anhydrous borax $\left(\mathrm{Na}_{2} \mathrm{~B}_{4} \mathrm{O}_{7}\right)$ for $\mathrm{NaBH}_{4}$ synthesis by ball milling method at room temperature (RT). Here, the $\mathrm{NaBH}_{4}$ yield may reach $78 \%$ with the addition of $\mathrm{Na}_{2} \mathrm{CO}_{3}$ [186]. This method introduces not only a novel reducing agent $\left(\mathrm{MgH}_{2}\right)$, but also an energy-efficient strategy for $\mathrm{NaBH}_{4}$ synthesis. Enlightened by this, RT ball milling became attractive in $\mathrm{NaBH}_{4}$ synthesis studies, by which $\mathrm{Na}$ and $\mathrm{MgH}_{2}$ could react with $\mathrm{B}_{2} \mathrm{O}_{3}$ with the $\mathrm{NaBH}_{4}$ yield of $25 \%$ [187]. As Na was replaced by safe and cheap $\mathrm{NaCl}, \mathrm{NaBH}_{4}$ could also be produced [188]. Subsequently, high-pressure milling was also developed to synthesize $\mathrm{NaBH}_{4}$. For instance, the synthesis of $\mathrm{NaBH}_{4}$ could be achieved by ball milling the hybrid of $\mathrm{NaH}$ and $\mathrm{MgB}_{2}$ under 120 bar $\mathrm{H}_{2}$ pressure with the yield of ca. $18 \%$ [189].

Importantly, considering the sustainability and environmental friendliness, $\mathrm{NaBH}_{4}$ regeneration from $\mathrm{NaBO}_{2} \cdot \mathrm{xH}_{2} \mathrm{O}$, the hydrolysis by-product, is appealing as the regeneration and hydrolysis form a recycling system. Since Kojima et al. [190] firstly achieved the regeneration of $\mathrm{NaBH}_{4}$ via reacting $\mathrm{MgH}_{2}$ with $\mathrm{NaBO}_{2}$ under 70 bar $\mathrm{H}_{2}$ pressure at $550{ }^{\circ} \mathrm{C}$ with a $~ 97 \%$ yield of $\mathrm{NaBH}_{4}, \mathrm{NaBO}_{2}$ has become the main research object for $\mathrm{NaBH}_{4}$ regeneration. Later, the thermochemistry process was substituted by RT ball milling because of high energy consumption under extreme conditions (high reaction temperature and high hydrogen pressure). Hsueh et al. [191-193] adopted $\mathrm{MgH}_{2}$ to react with anhydrous $\mathrm{NaBO}_{2}$ by ball milling under inert atmosphere. The conversion yields of $\mathrm{NaBH}_{4}$ were $>70 \%$, which indicated that ball milling is advisable for the reaction between $\mathrm{MgH}_{2}$ and $\mathrm{NaBO}_{2}$. Recently, Ouyang et al. [182, 183, 194] successfully achieved the regeneration of $\mathrm{NaBH}_{4}$ (Fig. 14) by applying the real hydrolysis by-product $\left(\mathrm{NaBO}_{2} \cdot 2 \mathrm{H}_{2} \mathrm{O}\right.$ and $\left.\mathrm{NaBO}_{2} \cdot 4 \mathrm{H}_{2} \mathrm{O}\right)$ as raw material with $\mathrm{Mg}$-based reducing agents $\left(\mathrm{Mg}, \mathrm{Mg}_{2} \mathrm{Si}\right.$ and $\left.\mathrm{Mg}_{17} \mathrm{Al}_{12}\right)$ at ambient conditions, where the troublesome heat-wasting process to obtain $\mathrm{NaBO}_{2}$ using a drying procedure at over $350{ }^{\circ} \mathrm{C}$ from $\mathrm{NaBO}_{2} \cdot \mathrm{xH}_{2} \mathrm{O}$ was omitted. The regeneration yield of $\mathrm{NaBH}_{4}$ may reach $78 \%$. Significantly, the charged $\mathrm{H}^{-}$stored in $\mathrm{NaBH}_{4}$ was completely converted from protonic $\mathrm{H}^{+}$in water bound to $\mathrm{NaBO}_{2}$. Particularly, it was found that the regeneration yield of $\mathrm{NaBH}_{4}$ was up $\sim 90 \%$, while $\mathrm{MgH}_{2}$ acted as reducing agent [195]. Recently, Ouyang et al. [196] found that high-energy ball milling of magnesium $(\mathrm{Mg})$ with the mixture of $\mathrm{Na}_{2} \mathrm{~B}_{4} \mathrm{O}_{7} \cdot \mathrm{xH}_{2} \mathrm{O}(\mathrm{x}=5,10)$ and $\mathrm{Na}_{2} \mathrm{CO}_{3}$ (obtained by exposing an aqueous solution of $\mathrm{NaBO}_{2}$ to $\mathrm{CO}_{2}$ ) resulted in the formation of $\mathrm{NaBH}_{4}$ with a high yield of $80 \%$ under ambient conditions. In their approach, after ball milling for just $10 \mathrm{~min}$, only $\mathrm{B}_{4} \mathrm{O}_{5}(\mathrm{OH})_{4}{ }^{2-}$ was detected (Fig. 15(1)), suggesting that the reaction started with this compound containing two $\mathrm{BO}_{4}$ tetrahedra and two $\mathrm{BO}_{3}$ triangles. The $\mathrm{B}-\mathrm{O}$ bond with a bond length of $1.4418 \AA$ in the $\mathrm{BO}_{4}$ tetrahedra is weaker than that $(1.3683 \AA)$ in the $\mathrm{BO}_{3}$ triangle. Thus, the $\mathrm{B}-\mathrm{O}$ bond in the $\mathrm{BO}_{4}$ tetrahedra preferentially broke via a $\mathrm{B}-\mathrm{O}-\mathrm{Mg}-\mathrm{H}$ intermediate, forming $\mathrm{B}-\mathrm{H}$ and $\mathrm{Mg}-\mathrm{O}$ (Fig. 15(2, 4)). In the following step, the cleavage of (B)-O-H (O bonded with $s p^{2}$ boron) formed the $\mathrm{H}_{2} \mathrm{BOH}$ intermediate (Fig. 15(5)), in which $\mathrm{B}$ acted as the Lewis acidic site that accepted $\mathrm{H}^{-}$from $\mathrm{MgH}_{2}$ leading to the formation of the final products, $\mathrm{BH}_{4}{ }^{-}$and $\mathrm{MgO}$. On the other hand, $\mathrm{OH}^{-}$bonded with $\mathrm{sp}^{3}$ boron (Fig. 15(3,4)) was also substituted by $\mathrm{H}^{-}$from $\mathrm{MgH}_{2}$, forming $\mathrm{BH}_{4}^{-}$. Furthermore, they achieved a higher yield of $93.1 \%$ for a short duration ( $3.5 \mathrm{~h})$ by ball milling hydrated borax $\left(\mathrm{Na}_{2} \mathrm{~B}_{4} \mathrm{O}_{7} \cdot 10 \mathrm{H}_{2} \mathrm{O}\right.$ and/ or $\mathrm{Na}_{2} \mathrm{~B}_{4} \mathrm{O}_{7} \cdot 5 \mathrm{H}_{2} \mathrm{O}$ ) with different reducing agents such as $\mathrm{MgH}_{2}, \mathrm{Mg}$, and $\mathrm{NaH}$ under ambient conditions [197]. By replacing the majority of $\mathrm{MgH}_{2}$ with low-cost $\mathrm{Mg}$, an attractive yield of $78.6 \%$ was obtained. These reactions occurred without extra hydrogen gas inputs, meaning the low-cost and sustainable regeneration. More detailed information toward $\mathrm{NaBH}_{4}$ regeneration can be found in a recent review [198].

In the past few years, numerous reports have been published dealing with the regeneration of $\mathrm{NaBH}_{4}$-based spent fuels $\left(\mathrm{NaBO}_{2} \cdot \mathrm{xH}_{2} \mathrm{O}\right.$ or $\left.\mathrm{Na}_{2} \mathrm{~B}_{4} \mathrm{O}_{7} \cdot \mathrm{xH}_{2} \mathrm{O}\right)$, whereas the studies upon the regeneration of $\mathrm{LiBH}_{4}$-based spent products were quite limited. Bilen et al. [199] firstly utilized $\mathrm{MgH}_{2}$ and $\mathrm{LiBO}_{2}$ to synthesize $\mathrm{LiBH}_{4}$ by means of mechano-chemical reaction. Instead of its elements, the hydrolytic product of $\mathrm{LiBH}_{4}\left(\mathrm{LiBO}_{2}\right)$ was adopted as raw material, which may 

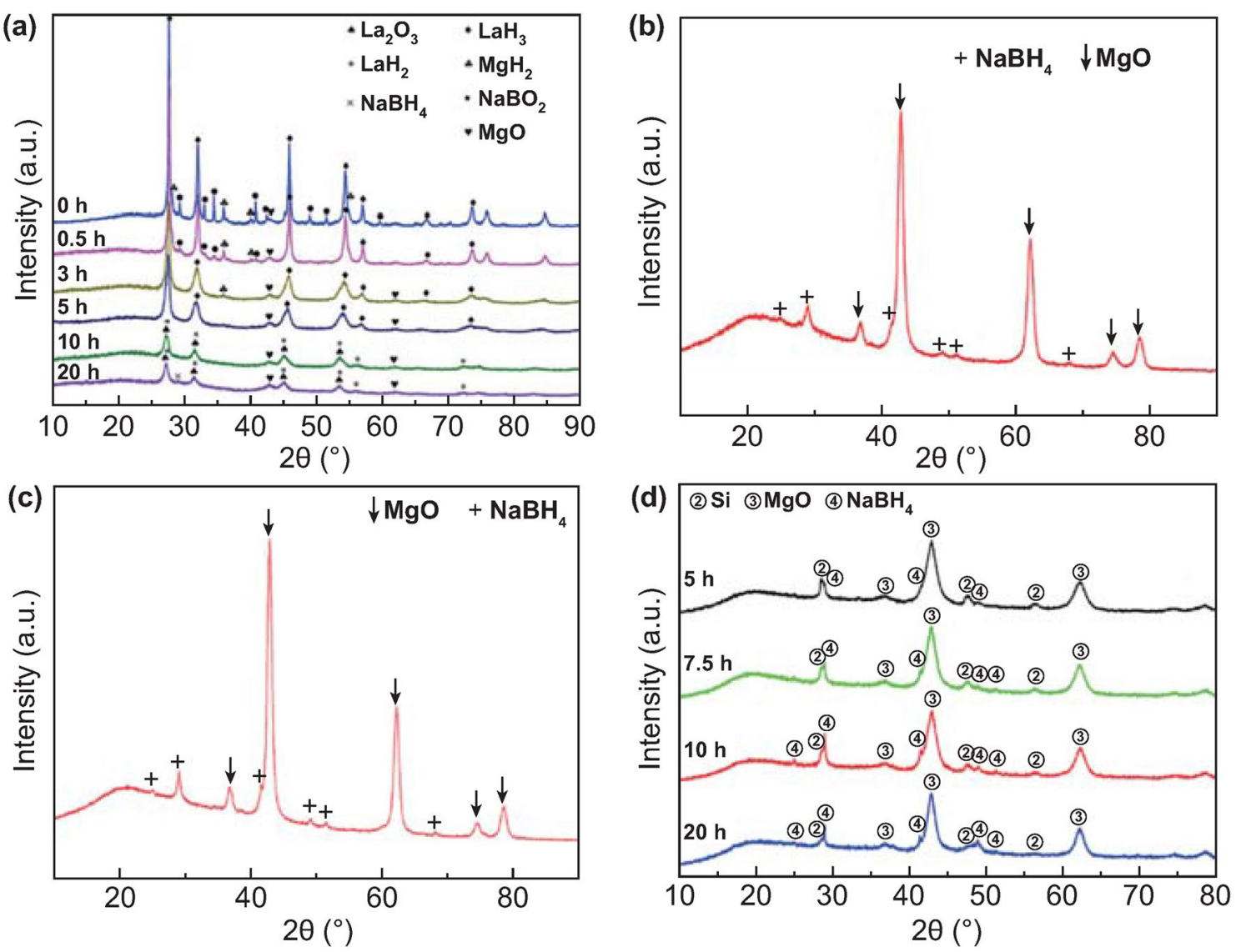

Fig. 14 a XRD patterns of the $\mathrm{NaBO}_{2}-\mathrm{Mg}_{3} \mathrm{La}$ hydride hybrids and the product after ball milling the $\mathrm{NaBO}_{2}-\mathrm{Mg}_{3} \mathrm{La}$ hydride mixture. $\mathbf{b}$ XRD pattern of products via ball milling the mixture of $\mathrm{NaBO}_{2} \cdot 2 \mathrm{H}_{2} \mathrm{O}-\mathrm{MgH}_{2}$ in 1:5.5 mol ratio for $15 \mathrm{~h}$. $\mathbf{c}$ XRD curve of products via ball milling the mixture of $\mathrm{NaBO}_{2} \cdot 2 \mathrm{H}_{2} \mathrm{O}-5 \mathrm{Mg}$ for $15 \mathrm{~h}$. d XRD spectra of the products after ball milling $\mathrm{Mg}_{2} \mathrm{Si}$ and $\mathrm{NaBO}_{2} \cdot 2 \mathrm{H}_{2} \mathrm{O}$ mixtures (in 2:1 mol ratio). Reprinted with permission from Ref. [198]. Copyright 2018 MDPI

greatly reduce the application cost of $\mathrm{LiBH}_{4}$ by recycling spent products. However, the tricky heating-wasting process for obtaining anhydrous $\mathrm{LiBO}_{2}$ at elevated temperature $\left(\sim 470{ }^{\circ} \mathrm{C}\right)$ is inevitable [200]. Stimulated by the successful regeneration of $\mathrm{NaBH}_{4}$, Ouyang et al. [201] reported a facile method to regenerate $\mathrm{LiBH}_{4}$ by ball milling its real hydrolysis by-product $\left(\mathrm{LiBO}_{2} \cdot 2 \mathrm{H}_{2} \mathrm{O}\right)$ with $\mathrm{Mg}$ under ambient conditions with a yield of $\sim 40 \%$. This method bypasses

(3)

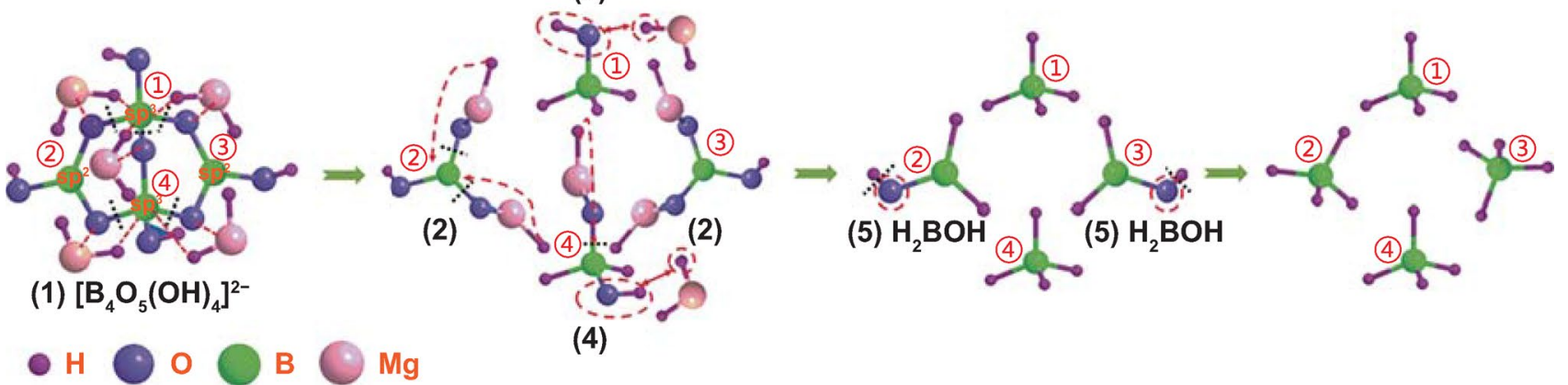

Fig. 15 Proposed reaction mechanism between $\mathrm{Mg}, \mathrm{Na}_{2} \mathrm{CO}_{3}$, and $\mathrm{Na}_{2} \mathrm{~B}_{4} \mathrm{O}_{7} \cdot 10 \mathrm{H}_{2} \mathrm{O}$ to form $\mathrm{NaBH}_{4}$. Reprinted with permission from Ref. [196]. Copyright 2020 Wiley Online Library 
the energy-intensive dehydration procedure to remove water from $\mathrm{LiBO}_{2} \cdot 2 \mathrm{H}_{2} \mathrm{O}$ and does not require high-pressure $\mathrm{H}_{2}$ gas, therefore leading to much reduced costs. Interestingly, it is expected to effectively close the loop of $\mathrm{LiBH}_{4}$ regeneration and hydrolysis, enabling a wide deployment of $\mathrm{LiBH}_{4}$ for hydrogen storage and application. As same as $\mathrm{NaBH}_{4}$ or $\mathrm{LiBH}_{4}, \mathrm{KBH}_{4}$ could also be synthesized by mechanochemical reaction. Bilen et al. [202] successfully synthesized $\mathrm{KBH}_{4}$ by ball milling $\mathrm{KCl}, \mathrm{MgH}_{2}$, and $\mathrm{B}_{2} \mathrm{O}_{3}$ in a milling reactor. By tailoring the reactant ratio $\left(\mathrm{MgH}_{2} / \mathrm{KCl}\right)$ and the milling time, the yield of the reaction reached maximum values, whereas the definite value was not given.

Application of borohydride hydrolysis is limited by limit of their effective regeneration. Though the great achievements have been attained in the regeneration of $\mathrm{NaBH}_{4}$, simplifying synthetic routes and increasing regeneration yield that enable the efficient energy storage and conversion of the "one-pass" hydrogen fuel are two critical targets for large-scale applications. For the anhydrous $\mathrm{NaBO}_{2}$ recycling, it was found that $\mathrm{MgH}_{2}$ has the best reducing effect. However, its high cost, resulting from the high hydrogenation temperature of $\mathrm{Mg}$, limits the application of such methods. For the direct $\mathrm{NaBH}_{4}$-based spent fuels $\left(\mathrm{NaBO}_{2} \cdot \mathrm{xH}_{2} \mathrm{O}\right.$ or $\mathrm{Na}_{2} \mathrm{~B}_{4} \mathrm{O}_{7} \cdot \mathrm{xH}_{2} \mathrm{O}$ ), they can be reduced to $\mathrm{NaBH}_{4}$ with different reductants $\left(\mathrm{MgH}_{2}, \mathrm{Mg}\right.$, or $\left.\mathrm{Mg}_{2} \mathrm{Si}\right)$ via ball milling, and the highest yield of $\mathrm{NaBH}_{4}$ may reach $93.1 \%$. Moreover, this process, that uses hydrated metaborate or borax, bypasses the energy-intensive dehydration procedure to obtain anhydrous $\mathrm{NaBO}_{2}$ or $\mathrm{Na}_{2} \mathrm{~B}_{4} \mathrm{O}_{7}$ without the requirement of high-pressure $\mathrm{H}_{2}$ gas; therefore, it could lead to much reduced costs. The boron compounds bound with water may act as hydrogen sources stored in $\mathrm{NaBH}_{4}$ instead of $\mathrm{MgH}_{2}$. As expected, lowcost waste $\mathrm{Al}$ or Al-based alloys may be attractive for achieving the regeneration of $\mathrm{NaBH}_{4}$ via ball milling, enabling a wide deployment of $\mathrm{NaBH}_{4}$ for hydrogen applications. This strategy may provide a new conceptual basis for the development of $\mathrm{LiBH}_{4}$ production or other borohydrides.

\section{Conclusions}

The present review narrates the recent research progress of hydrogen generation via hydrolysis or alcoholysis by light metal-based materials for potential off- or on-board hydrogen applications, predominantly including borohydrides and Mg-/Al-based materials. The mechanisms of catalytic borohydride hydrolysis and activation of aluminumbased materials via alloying are depicted. Various common methods such as ball milling, catalysis, alloying, and solution modification for improving hydrolysis kinetics are described in detail. In summary, ball milling can refine the particles size to increase reaction activity, but it is unsuitable for practical use in the transportation and storage of the powder. For the hydrolysis of borohydrides, the $\mathrm{Co}-\mathrm{B}-$ based materials are commonly considered as reactive as noble metals and much more cost-effective. Other metals and Co may form a synergistic effect in Co-B-based ternary or quaternary catalysts. The (catalyzed) hydrolysis of $\mathrm{Mg}$-/Al-based materials has been summarized. The alcoholysis operated at low temperatures can supply hydrogen for special subzero circumstances. The cost is substantially decreased in regeneration of sodium borohydride, making hydrolysis/alcoholysis more practical for on-site hydrogen applications or fuel cells with the advantages of mild operating temperature, environmentally benign by-products, precise controllable of hydrogen release and high-purity $\mathrm{H}_{2}$. However, the major exothermicity of hydrolysis reactions has not received enough attention, which is even more than the hydrogen energy. The improvement of controllability of hydrolysis helps to design novel on-board hydrogen supply systems.

Acknowledgements This work was financially supported by the National Key R\&D Program of China (2018YFB1502101), the Foundation for Innovative Research Groups of the National Natural Science Foundation of China (NSFC51621001), National Natural Science Foundation of China Projects (51771075) and Natural Science Foundation of Guangdong Province of China (2016A030312011). Z.L. acknowledges the funding support from the Australian Research Council (ARC Discovery Projects, DP180102976 and DP210103539).

Open Access This article is licensed under a Creative Commons Attribution 4.0 International License, which permits use, sharing, adaptation, distribution and reproduction in any medium or format, as long as you give appropriate credit to the original author(s) and the source, provide a link to the Creative Commons licence, and indicate if changes were made. The images or other third party material in this article are included in the article's Creative Commons licence, unless indicated otherwise in a credit line to the material. If material is not included in the article's Creative Commons licence and your intended use is not permitted by statutory regulation or exceeds the permitted use, you will need to obtain permission directly from the copyright holder. To view a copy of this licence, visit http://creativecommons.org/licenses/by/4.0/. 


\section{References}

1. W. Winsche, K.C. Hoffman, F. Salzano, Hydrogen: its future role in the nation's energy economy. Science 180(4093), 1325-1332 (1973). https://doi.org/10.1126/ science.180.4093.1325

2. X.N. Huang, T. Gao, X.L. Pan, D. Wei, C.J. Lv et al., A review: Feasibility of hydrogen generation from the reaction between aluminum and water for fuel cell applications. J. Power Sources 229, 133-140 (2013). https://doi.org/10. 1016/j.jpowsour.2012.12.016

3. S. Ahmed, M. Krumpelt, Hydrogen from hydrocarbon fuels for fuel cells. Int. J. Hydrog. Energy 26(4), 291-301 (2001). https://doi.org/10.1016/S0360-3199(00)00097-5

4. X. Cheng, Z. Shi, N. Glass, L. Zhang, J. Zhang et al., A review of PEM hydrogen fuel cell contamination: Impacts, mechanisms, and mitigation. J. Power Sources 165(2), 739-756 (2007). https://doi.org/10.1016/j.jpowsour.2006. 12.012

5. L. Schlapbach, A. Zuttel, Hydrogen-storage materials for mobile applications. Nature 414(6861), 353-358 (2001). https://doi.org/10.1038/35104634

6. A.E. Lutz, R.S. Larson, J.O. Keller, Thermodynamic comparison of fuel cells to the Carnot cycle. Int. J. Hydrog. Energy 27(10), 1103-1111 (2002). https://doi.org/10.1016/ S0360-3199(02)00016-2

7. M.P. Suh, H.J. Park, T.K. Prasad, D.W. Lim, Hydrogen storage in metal-organic frameworks. Chem. Rev. 112(2), 782-835 (2012). https://doi.org/10.1021/cr200274s

8. U. Eberle, M. Felderhoff, F. Schuth, Chemical and physical solutions for hydrogen storage. Angew. Chem. Int. Ed. 48(36), 6608-6630 (2009). https://doi.org/10.1002/anie. 200806293

9. R. Jain, A. Jain, S. Agarwal, N. Lalla, V. Ganesan et al., Hydrogenation behaviour of Ce-based AB5 intermetallic compounds. J. Alloy Compd. 440(1-2), 84-88 (2007). https://doi.org/10.1016/j.jallcom.2006.08.326

10. A.W.C. van den Berg, C.O. Areán, Materials for hydrogenstorage: current research trends and perspectives. Chem. Commun. 6, 668-681 (2008). https://doi.org/10.1039/ B712576N

11. N.T. Stetson, Hydrogen storage program area: plenary presentation (US Department of Energy, 2017).

12. A. Yamashita, M. Kondo, S. Goto, N. Ogami, Development of high-pressure hydrogen storage system for the Toyota "Mirai." SAE Technical Paper Series (2015). https://doi. org/10.4271/2015-01-1169

13. M. Aziz, A.T. Wijayanta, A.B.D. Nandiyanto, Ammonia as effective hydrogen storage: a review on production, storage and utilization. Energies 13(12), 3062 (2020). https://doi. org/10.3390/en13123062

14. M. Felderhoff, C. Weidenthaler, R. von Helmolt, U. Eberle, Hydrogen storage: the remaining scientific and technological challenges. Phys. Chem. Chem. Phys. 9(21), 2643-2653 (2007). https://doi.org/10.1039/b701563c
15. K. Wang, Z. Pan, X. Yu, Metal B-N-H hydrogen-storage compound: Development and perspectives. J. Alloys Compound. 794, 303-324 (2019). https://doi.org/10.1016/j.jallc om.2019.04.240

16. N.Z.A.K. Khafidz, Z. Yaakob, K.L. Lim, S.N. Timmiati, The kinetics of lightweight solid-state hydrogen storage materials: A review. Int. J. Hydrog. Energy 41(30), 1313113151 (2016). https://doi.org/10.1016/j.ijhydene.2016.05. 169

17. A.T. Wijayanta, T. Oda, C.W. Purnomo, T. Kashiwagi, M. Aziz, Liquid hydrogen, methylcyclohexane, and ammonia as potential hydrogen storage: Comparison review. Int. J. Hydrog. Energy 44(29), 15026-15044 (2019). https://doi. org/10.1016/j.jihydene.2019.04.112

18. S. Kumar, A. Jain, T. Ichikawa, Y. Kojima, G.K. Dey, Development of vanadium based hydrogen storage material: A review. Renew. Sust. Energ. Rev. 72, 791-800 (2017). https:// doi.org/10.1016/j.rser.2017.01.063

19. A. Jain, R. Jain, S. Agarwal, V. Ganesan, N. Lalla et al., Synthesis, characterization and hydrogenation of $\mathrm{ZrFe} 2-\mathrm{xNix}$ $(\mathrm{x}=0.2,0.4,0.6,0.8)$ alloys. Int. J. Hydrog. Energy 32(16), 3965-3971 (2007). https://doi.org/10.1016/j.ijhydene.2007. 05.001

20. I. Jain, P. Jain, A. Jain, Novel hydrogen storage materials: a review of lightweight complex hydrides. J. Alloy Compd. 503(2), 303-339 (2010). https://doi.org/10.1016/j.jallcom. 2010.04.250

21. A. Jain, E. Kawasako, H. Miyaoka, T. Ma, S. Isobe et al., Destabilization of LiH by Li insertion into Ge. J. Phys. Chem. C 117(11), 5650-5657 (2013). https://doi.org/10.1021/jp400 $133 \mathrm{t}$

22. T. Zhang, S. Isobe, A. Jain, Y. Wang, S. Yamaguchi et al., Enhancement of hydrogen desorption kinetics in magnesium hydride by doping with lithium metatitanate. J. Alloy Compd. 711, 400-405 (2017). https://doi.org/10.1016/j.jallcom.2017. 03.361

23. V.A. Yartys, M.V. Lototskyy, E. Akiba, R. Albert, V.E. Antonov et al., Magnesium based materials for hydrogen based energy storage: Past, present and future. Int. J. Hydrog. Energy 44(15), 7809-7859 (2019). https://doi.org/10.1016/j. ijhydene.2018.12.212

24. M. Jangir, A. Jain, S. Agarwal, T. Zhang, S. Kumar et al., The enhanced de/re-hydrogenation performance of $\mathrm{MgH}_{2}$ with $\mathrm{TiH}_{2}$ additive. Int. J. Energ. Res. 42(3), 1139-1147 (2018). https://doi.org/10.1002/er.3911

25. S. Kumar, A. Jain, H. Miyaoka, T. Ichikawa, Y. Kojima, Catalytic effect of bis (cyclopentadienyl) nickel II on the improvement of the hydrogenation-dehydrogenation of $\mathrm{Mg}-\mathrm{MgH}_{2}$ system. Int. J. Hydrog. Energy 42(27), 17178-17183 (2017). https://doi.org/10.1016/j.ijhydene.2017.05.090

26. C.W. Hamilton, R.T. Baker, A. Staubitz, I. Manners, B-N compounds for chemical hydrogen storage. Chem. Soc. Rev. 38(1), 279-293 (2009). https://doi.org/10.1039/B800312M

27. S. Liu, J. Liu, X. Liu, J. Shang, L. Xu et al., Hydrogen storage in incompletely etched multilayer $\mathrm{Ti}_{2} \mathrm{CT}_{\mathrm{x}}$ at room 
temperature. Nat. Nanotechnol. 16, 331-336 (2021). https:// doi.org/10.1038/s41565-020-00818-8

28. S. Kumar, U. Jain, A. Jain, H. Miyaoka, T. Ichikawa et al., Development of $\mathrm{MgLiB}$ based advanced material for onboard hydrogen storage solution. Int. J. Hydrog. Energy 42(7), 3963-3970 (2017). https://doi.org/10.1016/j.ijhydene.2016. 10.061

29. A. Borgschulte, E. Callini, B. Probst, A. Jain, S. Kato et al., Impurity gas analysis of the decomposition of complex hydrides. J. Phys. Chem. C 115(34), 17220-17226 (2011). https://doi.org/10.1021/jp205566q

30. H. Miyaoka, H. Miyaoka, T. Ichikawa, Y. Kojima, Highly purified hydrogen production from ammonia for PEM fuel cell. Int. J. Hydrog. Energy 43(31), 14486-14492 (2018). https://doi.org/10.1016/j.ijhydene.2018.06.065

31. K. Eom, E. Cho, H. Kwon, Feasibility of on-board hydrogen production from hydrolysis of Al-Fe alloy for PEMFCs. Int. J. Hydrog. Energy 36(19), 12338-12342 (2011). https://doi. org/10.1016/j.ijhydene.2011.06.099

32. C. Lang, Y. Jia, X. Yao, Recent advances in liquid-phase chemical hydrogen storage. Energy Storage Mater. 26, 290 312 (2020). https://doi.org/10.1016/j.ensm.2020.01.010

33. C. Wang, D. Astruc, Recent developments of nanocatalyzed liquid-phase hydrogen generation. Chem. Soc. Rev. 50, 34373484 (2021). https://doi.org/10.1039/D0CS00515K

34. S. Selvaraj, A. Jain, S. Kumar, T. Zhang, S. Isobe et al., Study of cyclic performance of V-Ti-Cr alloys employed for hydrogen compressor. Int. J. Hydrog. Energy 43(5), 2881-2889 (2018). https://doi.org/10.1016/j.ijhydene.2017.12.159

35. M.H. Grosjean, M. Zidoune, J.Y. Huot, L. Roue, Hydrogen generation via alcoholysis reaction using ball-milled $\mathrm{Mg}$ based materials. Int. J. Hydrog. Energy 31(9), 1159-1163 (2006). https://doi.org/10.1016/j.ijhydene.2005.10.001

36. M. Wang, L. Ouyang, C. Peng, X. Zhu, W. Zhu et al., Synthesis and hydrolysis of $\mathrm{NaZn}\left(\mathrm{BH}_{4}\right)_{3}$ and its ammoniates. J. Mater. Chem. A 5(32), 17012-17020 (2017). https://doi.org/ 10.1039/C7TA05082H

37. D.-W. Zhuang, H.-B. Dai, P. Wang, Hydrogen generation from solvolysis of sodium borohydride in ethylene glycolwater mixtures over a wide range of temperature. RSC Adv. 3(45), 23810 (2013). https://doi.org/10.1039/c3ra43136c

38. M. Ma, L. Ouyang, J. Liu, H. Wang, H. Shao et al., Air-stable hydrogen generation materials and enhanced hydrolysis performance of $\mathrm{MgH}_{2}-\mathrm{LiNH}_{2}$ composites. J. Power Sources 359, 427-434 (2017). https://doi.org/10.1016/j.jpowsour.2017.05. 087

39. S. Kumar, A. Jain, H. Miyaoka, T. Ichikawa, Y. Kojima, Study on the thermal decomposition of $\mathrm{NaBH}_{4}$ catalyzed by $\mathrm{ZrCl}_{4}$. Int. J. Hydrog. Energy 42(35), 22432-22437 (2017). https://doi.org/10.1016/j.ijhydene.2017.02.060

40. S. Kumar, A. Singh, K. Nakajima, A. Jain, H. Miyaoka et al., Improved hydrogen release from magnesium borohydride by $\mathrm{ZrCl}_{4}$ additive. Int. J. Hydrog. Energy 42(35), 22342-22347 (2017). https://doi.org/10.1016/j.ijhydene.2016.12.090
41. A. Borgschulte, A. Jain, A.J. Ramirez-Cuesta, P. Martelli, A. Remhof et al., Mobility and dynamics in the complex hydrides $\mathrm{LiAlH}_{4}$ and $\mathrm{LiBH}_{4}$. Faraday Discuss 151, 213-230 (2011). https://doi.org/10.1039/c0fd00011f

42. V. Kong, Development of hydrogen storage for fuel cellgenerators. i: Hydrogen generation using hydrolysishydrides. Int. J. Hydrog. Energy 24(7), 665-675 (1999). https://doi. org/10.1016/S0360-3199(98)00113-X

43. M. Nie, Y. Zou, Y. Huang, J. Wang, Ni-Fe-B catalysts for $\mathrm{NaBH}_{4}$ hydrolysis. Int. J. Hydrog. Energy 37(2), 15681576 (2012). https://doi.org/10.1016/j.ijhydene.2011.10. 006

44. B. Chen, S.J. Chen, H.A. Bandal, R. Appiah-Ntiamoah, A.R. Jadhav et al., Cobalt nanoparticles supported on magnetic core-shell structured carbon as a highly efficient catalyst for hydrogen generation from $\mathrm{NaBH}_{4}$ hydrolysis. Int. J. Hydrog. Energy 43(19), 9296-9306 (2018). https://doi.org/10.1016/j. ijhydene.2018.03.193

45. P. Krishnan, T.H. Yang, W.Y. Lee, C.S. Kim, PtRu-LiCoO - an efficient catalyst for hydrogen generation from sodium borohydride solutions. J. Power Sources 143(1-2), 17-23 (2005). https://doi.org/10.1016/j.jpowsour.2004.12.007

46. U.B. Demirci, F. Garin, Kinetics of Ru-promoted sulphated zirconia catalysed hydrogen generation by hydrolysis of sodium tetrahydroborate. J. Mol. Catal. A Chem. 279(1), 57-62 (2008). https://doi.org/10.1016/j.molcata.2007.09.025

47. H. Inokawa, H. Driss, F. Trovela, H. Miyaoka, T. Ichikawa et al., Catalytic hydrolysis of sodium borohydride on Co catalysts. Int. J. Energ. Res. 40(15), 2078-2090 (2016). https:// doi.org/10.1002/er.3582

48. A.K. Figen, Dehydrogenation characteristics of ammonia borane via boron-based catalysts $(\mathrm{Co}-\mathrm{B}, \mathrm{Ni}-\mathrm{B}, \mathrm{Cu}-\mathrm{B})$ under different hydrolysis conditions. Int. J. Hydrog. Energy 38(22), 9186-9197 (2013). https://doi.org/10.1016/j.ijhydene.2013. 05.081

49. H.J. Tian, Q.J. Guo, D.Y. Xu, Hydrogen generation from catalytic hydrolysis of alkaline sodium borohydride solution using attapulgite clay-supported Co-B catalyst. J. Power Sources 195(8), 2136-2142 (2010). https://doi.org/10.1016/j. jpowsour.2009.10.006

50. F. Li, Q. Li, H. Kim, CoB/open-CNTs catalysts for hydrogen generation from alkaline $\mathrm{NaBH}_{4}$ solution. Chem. Eng. J. 210, 316-324 (2012). https://doi.org/10.1016/j.cej.2012.08.102

51. Y.S. Wei, W. Meng, Y. Wang, Y.X. Gao, K.Z. Qi, K. Zhang, Fast hydrogen generation from $\mathrm{NaBH}_{4}$ hydrolysis catalyzed by nanostructured Co-Ni-B catalysts. Int. J. Hydrog. Energy 42(9), 6072-6079 (2017). https://doi.org/10.1016/j.ijhydene. 2016.11.134

52. Y.C. Lu, M.S. Chen, Y.W. Chen, Hydrogen generation by sodium borohydride hydrolysis on nanosized $\mathrm{CoB}$ catalysts supported on $\mathrm{TiO}_{2}, \mathrm{Al}_{2} \mathrm{O}_{3}$ and $\mathrm{CeO}_{2}$. Int. J. Hydrog. Energy 37(5), 4254-4258 (2012). https://doi.org/10.1016/j.ijhydene. 2011.11.105

53. E. Marreroalfonso, J. Gray, T. Davis, M. Matthews, Hydrolysis of sodium borohydride with steam. Int. J. Hydrog. Energy 
32(18), 4717-4722 (2007). https://doi.org/10.1016/j.ijhydene. 2007.07.066

54. A.F. Baye, M.W. Abebe, R. Appiah-Ntiamoah, H. Kim, Engineered iron-carbon-cobalt $\left(\mathrm{Fe}_{3} \mathrm{O}_{4} @ \mathrm{C}\right.$-Co) core-shell composite with synergistic catalytic properties towards hydrogen generation via $\mathrm{NaBH}_{4}$ hydrolysis. J. Colloid Interf. Sci. 543, 273-284 (2019). https://doi.org/10.1016/j.jcis.2019.02.065

55. K. Holbrook, P. Twist, Hydrolysis of the borohydride ion catalysed by metal-boron alloys. J. Chem. Soci. A: Inorg. Phys. Theor. (1971). https://doi.org/10.1039/J19710000890

56. N. Patel, R. Fernandes, A. Miotello, Promoting effect of transition metal-doped Co-B alloy catalysts for hydrogen production by hydrolysis of alkaline $\mathrm{NaBH}_{4}$ solution. J. Catal. 271(2), 315-324 (2010). https://doi.org/10.1016/j.jcat.2010. 02.014

57. U.B. Demirci, About the Technological Readiness of the H-2 Generation by Hydrolysis of B(-N)-H Compounds. Energy Technol-Ger 6(3), 470-486 (2018). https://doi.org/10.1002/ ente. 201700486

58. H.A. Bandal, A.R. Jadhav, H. Kim, Cobalt impregnated magnetite-multiwalled carbon nanotube nanocomposite as magnetically separable efficient catalyst for hydrogen generation by $\mathrm{NaBH}_{4}$ hydrolysis. J. Alloy. Compd. 699, 1057-1067 (2017). https://doi.org/10.1016/j.jallcom.2016.12.428

59. F. Li, E.E. Arthur, D. La, Q.M. Li, H. Kim, Immobilization of $\mathrm{CoCl}_{2}$ (cobalt chloride) on PAN (polyacrylonitrile) composite nanofiber mesh filled with carbon nanotubes for hydrogen production from hydrolysis of $\mathrm{NaBH}_{4}$ (sodium borohydride). Energy 71, 32-39 (2014). https://doi.org/10.1016/j.energy. 2014.03.130

60. G.R.M. Tomboc, A.H. Tamboli, H. Kim, Synthesis of $\mathrm{Co}_{3} \mathrm{O}_{4}$ macrocubes catalyst using novel chitosan/urea template for hydrogen generation from sodium borohydride. Energy 121, 238-245 (2017). https://doi.org/10.1016/j.energy.2017.01. 027

61. Y.Y. Huang, K.Y. Wang, L. Cui, W.X. Zhu, A.M. Asiri et al., Effective hydrolysis of sodium borohydride driven by selfsupported cobalt oxide nanorod array for on-demand hydrogen generation. Catal. Commun. 87, 94-97 (2016). https:// doi.org/10.1016/j.catcom.2016.09.012

62. M.H. Loghmani, A.F. Shojaei, Hydrogen production through hydrolysis of sodium borohydride: Oleic acid stabilized CoLa-Zr-B nanoparticle as a novel catalyst. Energy 68, 152-159 (2014). https://doi.org/10.1016/j.energy.2014.02.047

63. F. Seven, N. Sahiner, Enhanced catalytic performance in hydrogen generation from $\mathrm{NaBH}_{4}$ hydrolysis by super porous cryogel supported Co and Ni catalysts. J. Power Sources 272, 128-136 (2014). https://doi.org/10.1016/j.jpowsour.2014.08. 047

64. A.R. Jadhav, H.A. Bandal, H. Kim, $\mathrm{NiCo}_{2} \mathrm{O}_{4}$ hollow sphere as an efficient catalyst for hydrogen generation by $\mathrm{NaBH}_{4}$ hydrolysis. Mater. Lett. 198, 50-53 (2017). https://doi.org/ 10.1016/j.matlet.2017.03.161

65. F. Baydaroglu, E. Ozdemir, A. Hasimoglu, An effective synthesis route for improving the catalytic activity of carbonsupported Co-B catalyst for hydrogen generation through hydrolysis of $\mathrm{NaBH}_{4}$. Int. J. Hydrog. Energy 39(3), 15161522 (2014). https://doi.org/10.1016/j.ijhydene.2013.04.111

66. Y.P. Guo, Z.P. Dong, Z.K. Cui, X.J. Zhang, J.T. Ma, Promoting effect of $\mathrm{W}$ doped in electrodeposited Co-P catalysts for hydrogen generation from alkaline $\mathrm{NaBH}_{4}$ solution. Int. J. Hydrog. Energy 37(2), 1577-1583 (2012). https://doi.org/10. 1016/j.ijhydene.2011.10.019

67. L.N. Wang, Z. Li, P.P. Zhang, G.X. Wang, G.W. Xie, Hydrogen generation from alkaline $\mathrm{NaBH}_{4}$ solution using Co-NiMo-P/gamma- $\mathrm{Al}_{2} \mathrm{O}_{3}$ catalysts. Int. J. Hydrog. Energy 41(3), 1468-1476 (2016). https://doi.org/10.1016/j.ijhydene.2015. 11.028

68. Y. Wang, Y. Shen, K.Z. Qi, Z.Q. Cao, K. Zhang et al., Nanostructured cobalt-phosphorous catalysts for hydrogen generation from hydrolysis of sodium borohydride solution. Renew Energ. 89, 285-294 (2016). https://doi.org/10.1016/j.renene. 2015.12.026

69. K. Eom, K. Cho, H. Kwon, Effects of electroless deposition conditions on microstructures of cobalt-phosphorous catalysts and their hydrogen generation properties in alkaline sodium borohydride solution. J. Power Sources 180(1), 484-490 (2008). https://doi.org/10.1016/j.jpowsour.2008.01. 095

70. Y.P. Guo, Q.H. Feng, Z.P. Dong, J.T. Ma, Electrodeposited amorphous Co-P catalyst for hydrogen generation from hydrolysis of alkaline sodium borohydride solution. J. Mol. Catal. A-Chem. 378, 273-278 (2013). https://doi.org/10. 1016/j.molcata.2013.06.018

71. Y. Wang, K.Z. Qi, S.W. Wu, Z.Q. Cao, K. Zhang et al., Preparation, characterization and catalytic sodium borohydride hydrolysis of nanostructured cobalt-phosphorous catalysts. J. Power Sources 284, 130-137 (2015). https://doi.org/10. 1016/j.jpowsour.2015.03.013

72. Y.C. Zhao, Z. Ning, J.N. Tian, H.W. Wang, X.Y. Liang et al., Hydrogen generation by hydrolysis of alkaline $\mathrm{NaBH}_{4}$ solution on Co-Mo-Pd-B amorphous catalyst with efficient catalytic properties. J. Power Sources 207, 120-126 (2012). https://doi.org/10.1016/j.jpowsour.2012.01.118

73. K. Shimoda, K. Doi, T. Nakagawa, Y. Zhang, H. Miyaoka et al., Comparative study of structural changes in $\mathrm{NH}_{3} \mathrm{BH}_{3}$, $\mathrm{LiNH}_{2} \mathrm{BH}_{3}$, and $\mathrm{KNH}_{2} \mathrm{BH}_{3}$ during dehydrogenation process. J. Phys. Chem. C 116(9), 5957-5964 (2012). https://doi.org/ 10.1021/jp212351f

74. P.Z. Li, K. Aranishi, Q. Xu, ZIF-8 immobilized nickel nanoparticles: highly effective catalysts for hydrogen generation from hydrolysis of ammonia borane. Chem. Commun. 48(26), 3173-3175 (2012). https://doi.org/10.1039/c2cc1 $7302 \mathrm{f}$

75. C. Wang, J. Tuninetti, Z. Wang, C. Zhang, R. Ciganda et al., Hydrolysis of ammonia-borane over Ni/ZIF-8 nanocatalyst: high efficiency, mechanism, and controlled hydrogen release. J. Am. Chem. Soc. 139(33), 11610-11615 (2017). https://doi. org/10.1021/jacs.7b06859

76. Z. Li, T. He, L. Liu, W. Chen, M. Zhang et al., Covalent triazine framework supported non-noble metal nanoparticles with superior activity for catalytic hydrolysis of ammonia 
borane: from mechanistic study to catalyst design. Chem. Sci. 8(1), 781-788 (2017). https://doi.org/10.1039/C6SC02456D

77. F. Fu, C. Wang, Q. Wang, A.M. Martinez-Villacorta, A. Escobar, H. Chong et al., Highly selective and sharp volcano-type synergistic $\mathrm{Ni}_{2} \mathrm{Pt} @ \mathrm{ZIF}-8$-catalyzed hydrogen evolution from ammonia borane hydrolysis. J. Am. Chem. Soc. 140(31), 10034-10042 (2018). https://doi.org/10.1021/jacs.8b06511

78. M. Wang, L. Ouyang, M. Zeng, J. Liu, C. Peng et al., Magnesium borohydride hydrolysis with kinetics controlled by ammoniate formation. Int. J. Hydrog. Energy 44(14), 7392-7401 (2019). https://doi.org/10.1016/j.ijhydene.2019. 01.209

79. M.C. Wang, L.Z. Ouyang, J.W. Liu, H. Wang, M. Zhu, Hydrogen generation from sodium borohydride hydrolysis accelerated by zinc chloride without catalyst: A kinetic study. J. Alloy Compd. 717, 48-54 (2017). https://doi.org/10.1016/j. jallcom.2017.04.274

80. T. Zhang, Y. Wang, T. Song, H. Miyaoka, K. Shinzato et al., Ammonia, a switch for controlling high ionic conductivity in lithium borohydride ammoniates. Joule 2(8), 1522-1533 (2018). https://doi.org/10.1016/j.joule.2018.04.015

81. M.V. Solovev, O.V. Chashchikhin, P.V. Dorovatovskii, V.N. Khrustalev, A.S. Zyubin et al., Hydrolysis of $\mathrm{Mg}\left(\mathrm{BH}_{4}\right)(2)$ and its coordination compounds as a way to obtain hydrogen. J. Power Sources 377, 93-102 (2018). https://doi.org/10.1016/j. jpowsour.2017.11.090

82. J. Chang, H.J. Tian, F.L. Du, Investigation into hydrolysis and alcoholysis of sodium borohydride in ethanol-water solutions in the presence of supported Co-Ce-B catalyst. Int. J. Hydrog. Energy 39(25), 13087-13097 (2014). https://doi.org/ 10.1016/j.ijhydene.2014.06.150

83. V.R. Fernandes, A.M.F.R. Pinto, C.M. Rangel, Hydrogen production from sodium borohydride in methanol-water mixtures. Int. J. Hydrog. Energy 35(18), 9862-9868 (2010). https://doi.org/10.1016/j.ijhydene.2009.11.064

84. J.S. Zhang, T.S. Fisher, J.P. Gore, D. Hazra, P.V. Ramachandran, Heat of reaction measurements of sodium borohydride alcoholysis and hydrolysis. Int. J. Hydrog. Energy 31(15), 2292-2298 (2006). https://doi.org/10.1016/j.ijhydene.2006. 02.026

85. K. Ramya, K.S. Dhathathreyan, J. Sreenivas, S. Kumar, S. Narasimhan, Hydrogen production by alcoholysis of sodium borohydride. Int. J. Energ. Res. 37(14), 1889-1895 (2013). https://doi.org/10.1002/er.3006

86. L. Zhu, D. Kim, H. Kim, R.I. Masel, M.A. Shannon, Hydrogen generation from hydrides in millimeter scale reactors for micro proton exchange membrane fuel cell applications. J. Power Sources 185(2), 1334-1339 (2008). https://doi.org/10. 1016/j.jpowsour.2008.08.092

87. Y. Kojima, Y. Kawai, M. Kimbara, H. Nakanishi, S. Matsumoto, Hydrogen generation by hydrolysis reaction of lithium borohydride. Int. J. Hydrog. Energy 29(12), 1213-1217 (2004). https://doi.org/10.1016/j.ijhydene.2003.12.009

88. B. Weng, Z. Wu, Z. Li, H. Yang, H. Leng, Enhanced hydrogen generation by hydrolysis of $\mathrm{LiBH}_{4}$ doped with multiwalled carbon nanotubes for micro proton exchange membrane fuel cell application. J. Power Sources 196(11), 5095-5101 (2011). https://doi.org/10.1016/j.jpowsour.2011.01.080

89. B. Weng, Z. Wu, Z. Li, H. Yang, Enhanced hydrogen generation from hydrolysis of $\mathrm{LiBH}_{4}$ with diethyl ether addition for micro proton exchange membrane fuel cell application. J. Power Sources 204, 60-66 (2012). https://doi.org/10.1016/j. jpowsour.2012.01.051

90. B. Weng, Z. Wu, Z. Li, H. Yang, H. Leng, Hydrogen generation from noncatalytic hydrolysis of $\mathrm{LiBH}_{4} / \mathrm{NH}_{3} \mathrm{BH}_{3}$ mixture for fuel cell applications. Int. J. Hydrog. Energy 36(17), 10870-10876 (2011). https://doi.org/10.1016/j.ijhydene. 2011.06.009

91. Y. Kojima, K.-I. Suzuki, Y. Kawai, Hydrogen generation from lithium borohydride solution over nano-sized platinum dispersed on $\mathrm{LiCoO}_{2}$. J. Power Sources 155(2), 325-328 (2006). https://doi.org/10.1016/j.jpowsour.2005.04.019

92. K. Chen, L.Z. Ouyang, H. Wang, J.W. Liu, H.Y. Shao et al., A high-performance hydrogen generation system: Hydrolysis of $\mathrm{LiBH}_{4}$-based materials catalyzed by transition metal chlorides. Renew. Energy 156, 655-664 (2020). https://doi.org/ 10.1016/j.renene.2020.04.030

93. Z.H. Tan, L.Z. Ouyang, J.W. Liu, H. Wang, H.Y. Shao et al., Hydrogen generation by hydrolysis of $\mathrm{Mg}-\mathrm{Mg}_{2} \mathrm{Si}$ composite and enhanced kinetics performance from introducing of $\mathrm{MgCl}_{2}$ and Si. Int. J. Hydrog. Energy 43(5), 2903-2912 (2018). https://doi.org/10.1016/j.ijhydene.2017.12.163

94. M. Ma, R. Duan, L. Ouyang, X. Zhu, Z. Chen et al., Hydrogen storage and hydrogen generation properties of $\mathrm{CaMg}_{2}$-based alloys. J. Alloy Compd. 691, 929-935 (2017). https://doi.org/ 10.1016/j.jallcom.2016.08.307

95. I. Jain, C. Lal, A. Jain, Hydrogen storage in Mg: a most promising material. Int. J. Hydrog. Energy 35(10), 5133-5144 (2010). https://doi.org/10.1016/j.ijhydene.2009.08.088

96. M. Grosjean, M. Zidoune, L. Roue, J. Huot, Hydrogen production via hydrolysis reaction from ball-milled Mg-based materials. Int. J. Hydrog. Energy 31(1), 109-119 (2006). https://doi.org/10.1016/j.ijhydene.2005.01.001

97. J.M. Huang, L.Z. Ouyang, Y.J. Wen, H. Wang, J.W. Liu et al., Improved hydrolysis properties of $\mathrm{Mg}_{3} \mathrm{RE}$ hydrides alloyed with Ni. Int. J. Hydrog. Energy 39(13), 6813-6818 (2014). https://doi.org/10.1016/j.ijhydene.2014.02.155

98. M.H. Huang, L.Z. Ouyang, H. Wang, J.W. Liu, M. Zhu, Hydrogen generation by hydrolysis of $\mathrm{MgH}_{2}$ and enhanced kinetics performance of ammonium chloride introducing. Int. J. Hydrog. Energy 40(18), 6145-6150 (2015). https://doi.org/ 10.1016/j.ijhydene.2015.03.058

99. M. Huang, L. Ouyang, J. Ye, J. Liu, X. Yao et al., Hydrogen generation via hydrolysis of magnesium with seawater using $\mathrm{Mo}, \mathrm{MoO}_{2}, \mathrm{MoO}_{3}$ and $\mathrm{MoS}_{2}$ as catalysts. J. Mater. Chem. A 5(18), 8566-8575 (2017). https://doi.org/10.1039/C7TA0 $2457 \mathrm{~F}$

100. M.H. Huang, L.Z. Ouyang, J.W. Liu, H. Wang, H.Y. Shao et al., Enhanced hydrogen generation by hydrolysis of $\mathrm{Mg}$ doped with flower-like $\mathrm{MoS}_{2}$ for fuel cell applications. J. Power Sources 365, 273-281 (2017). https://doi.org/10. 1016/j.jpowsour.2017.08.097 
101. O.V. Kravchenko, L.G. Sevastyanova, S.A. Urvanov, B.M. Bulychev, Formation of hydrogen from oxidation of $\mathrm{Mg}, \mathrm{Mg}$ alloys and mixture with $\mathrm{Ni} \mathrm{Co}, \mathrm{Cu}$ and $\mathrm{Fe}$ in aqueous salt solutions. Int. J. Hydrog. Energy 39(11), 5522-5527 (2014). https://doi.org/10.1016/j.ijhydene.2014.01.181

102. L.Z. Ouyang, J.M. Huang, C.J. Fang, Q.A. Zhang, D.L. Sun et al., The controllable hydrolysis rate for $\mathrm{LaMg}_{12}$ hydride. Int. J. Hydrog. Energy 37(17), 12358-12364 (2012). https:// doi.org/10.1016/j.ijhydene.2012.05.098

103. L.Z. Ouyang, J.M. Huang, H. Wang, Y.J. Wen et al., Excellent hydrolysis performances of $\mathrm{Mg}_{3}$ RE hydrides. Int. J. Hydrog. Energy 38(7), 2973-2978 (2013). https://doi.org/10.1016/j. ijhydene.2012.12.092

104. L.Z. Ouyang, J.M. Huang, C.J. Fang, H. Wang, J.W. Liu et al., The high capacity and controllable hydrolysis rate of $\mathrm{Mg}_{3} \mathrm{La}$ hydride. J. Alloy Compd. 580, S317-S319 (2013). https://doi. org/10.1016/j.jallcom.2013.03.153

105. L.Z. Ouyang, Y.J. Xu, H.W. Dong, L.X. Sun, M. Zhu, Production of hydrogen via hydrolysis of hydrides in Mg-La system. Int. J. Hydrog. Energy 34(24), 9671-9676 (2009). https://doi. org/10.1016/j.ijhydene.2009.09.068

106. J.M. Huang, R.M. Duan, L.Z. Ouyang, Y.J. Wen, H. Wang et al., The effect of particle size on hydrolysis properties of $\mathrm{Mg}_{3} \mathrm{La}$ hydrides. Int. J. Hydrog. Energy 39(25), 13564-13568 (2014). https://doi.org/10.1016/j.ijhydene.2014.04.024

107. M.L. Ma, R.M. Duan, L.Z. Ouyang, X.K. Zhu, C.H. Peng et al., Hydrogen generation via hydrolysis of $\mathrm{H}-\mathrm{CaMg}_{2}$ and H-CaMg ${ }_{1.9} \mathrm{Ni}_{0.1}$. Int. J. Hydrog. Energy 42(35), 22312-22317 (2017). https://doi.org/10.1016/j.ijhydene.2017.05.159

108. M. Ma, K. Chen, J. Jiang, X. Yang, H. Wang et al., Enhanced hydrogen generation performance of $\mathrm{CaMg}_{2}$-based materials by ball milling. Inorg. Chem. Front. 7(4), 918-929 (2020). https://doi.org/10.1039/C9QI01299K

109. M.L. Ma, L.L. Yang, L.Z. Ouyang, H.Y. Shao, M. Zhu, Promoting hydrogen generation from the hydrolysis of $\mathrm{Mg}$ Graphite composites by plasma-assisted milling. Energy 167, 1205-1211 (2019). https://doi.org/10.1016/j.energy.2018.11. 029

110. J. Jiang, L. Ouyang, H. Wang, J. Liu, H. Shao et al., Controllable hydrolysis performance of $\mathrm{MgLi}$ alloys and their hydrides. ChemPhysChem 20(10), 1316-1324 (2019). https:// doi.org/10.1002/cphc.201900058

111. M.L. Ma, K. Chen, L.Z. Ouyang, J. Jiang, F. Liu et al., Kinetically controllable hydrogen generation at low temperatures by the alcoholysis of $\mathrm{CaMg}_{2}$-based materials in tailored solutions. Chemsuschem 13(10), 2709-2718 (2020). https://doi. org/10.1002/cssc.202000089

112. J. Chen, H. Fu, Y.F. Xiong, J.R. Xu, J. Zheng et al., $\mathrm{MgCl}_{2}$ promoted hydrolysis of $\mathrm{MgH}_{2}$ nanoparticles for highly efficient H-2 generation. Nano Energy 10, 337-343 (2014). https://doi.org/10.1016/j.nanoen.2014.10.002

113. Z.H. Tan, L.Z. Ouyang, J.M. Huang, J.W. Liu, H. Wang et al., Hydrogen generation via hydrolysis of $\mathrm{Mg}_{2} \mathrm{Si}$. J. Alloy Compd. 770, 108-115 (2019). https://doi.org/10.1016/j.jallc om.2018.08.122
114. Q. Sun, M.S. Zou, X.Y. Guo, R.J. Yang, H.T. Huang et al., A study of hydrogen generation by reaction of an activated $\mathrm{Mg}-\mathrm{CoCl}_{2}$ (magnesium-cobalt chloride) composite with pure water for portable applications. Energy 79, 310-314 (2015). https://doi.org/10.1016/j.energy.2014.11.016

115. S. Wang, L.X. Sun, F. Xu, C.L. Jiao, J. Zhang et al., Hydrolysis reaction of ball-milled $\mathrm{Mg}$-metal chlorides composite for hydrogen generation for fuel cells. Int. J. Hydrog. Energy 37(8), 6771-6775 (2012). https://doi.org/10.1016/j. ijhydene.2012.01.099

116. F. Xiao, Y.P. Guo, R.J. Yang, J.M. Li, Hydrogen generation from hydrolysis of activated magnesium/low-melting-point metals alloys. Int. J. Hydrog. Energy 44(3), 1366-1373 (2019). https://doi.org/10.1016/j.ijhydene.2018.11.165

117. S.L. Li, J.M. Song, J.Y. Uan, Mg-Mg2X ( $\mathrm{X}=\mathrm{Cu}, \mathrm{Sn})$ eutectic alloy for the $\mathrm{Mg}_{2} \mathrm{X}$ nano-lamellar compounds to catalyze hydrolysis reaction for $\mathrm{H}-2$ generation and the recycling of pure $\mathrm{X}$ metals from the reaction wastes. J. Alloy Compd. 772, 489-498 (2019). https://doi.org/10.1016/j.jallcom. 2018.09.154

118. E. Alasmar, I. Aubert, A. Durand, M. Nakhl, M. Zakhour et al., Hydrogen generation from $\mathrm{Mg}-\mathrm{NdNiMg}_{15}$ composites by hydrolysis reaction. Int. J. Hydrog. Energy 44(2), 523-530 (2019). https://doi.org/10.1016/j.ijhydene.2018. 10.233

119. A.S. Awad, E. El-Asmar, T. Tayeh, F. Mauvy, M. Nakhl et al., Effect of carbons ( $\mathrm{G}$ and $\mathrm{CFs}), \mathrm{TM}(\mathrm{Ni}, \mathrm{Fe}$ and $\mathrm{Al})$ and oxides $\left(\mathrm{Nb}_{2} \mathrm{O}_{5}\right.$ and $\left.\mathrm{V}_{2} \mathrm{O}_{5}\right)$ on hydrogen generation from ball milled $\mathrm{Mg}$-based hydrolysis reaction for fuel cell. Energy 95, 175186 (2016). https://doi.org/10.1016/j.energy.2015.12.004

120. P.P. Liu, H.W. Wu, C.L. Wu, Y.G. Chen, Y.M. Xu et al., Microstructure characteristics and hydrolysis mechanism of $\mathrm{Mg}-\mathrm{Ca}$ alloy hydrides for hydrogen generation. Int. J. Hydrog. Energy 40(10), 3806-3812 (2015). https://doi.org/ 10.1016/j.ijhydene.2015.01.105

121. Y.A. Liu, X.H. Wang, Z.H. Dong, H.Z. Liu, S.Q. Li et al., Hydrogen generation from the hydrolysis of Mg powder ballmilled with $\mathrm{AlCl}_{3}$. Energy 53, 147-152 (2013). https://doi. org/10.1016/j.energy.2013.01.073

122. X. Hou, Y. Wang, K. Hou, L. Yang, H. Shi et al., Outstanding hydrogen production properties of surface catalysts promoted $\mathrm{Mg}-\mathrm{Ni}-\mathrm{Ce}$ composites at room temperature in simulated seawater. J. Mater. Sci. 55(30), 14922-14937 (2020). https://doi. org/10.1007/s10853-020-05065-9

123. X. Hou, Y. Wang, Y. Yang, R. Hu, G. Yang et al., Microstructure evolution and controlled hydrolytic hydrogen generation strategy of Mg-rich Mg-Ni-La ternary alloys. Energy 188, 116081 (2019). https://doi.org/10.1016/j.energy.2019.116081

124. X.J. Hou, Y. Wang, Y.L. Yang, R. Hu, G. Yang et al., Enhanced hydrogen generation behaviors and hydrolysis thermodynamics of as-cast Mg-Ni-Ce magnesium-rich alloys in simulate seawater. Int. J. Hydrog. Energy 44(44), 2408624097 (2019). https://doi.org/10.1016/j.ijhydene.2019.07.148

125. X. Hou, Y. Wang, R. Hu, H. Shi, L. Feng et al., Catalytic effect of EG and MoS2 on hydrolysis hydrogen generation behavior of high-energy ball-milled $\mathrm{Mg}-10 \mathrm{wt}$.\% Ni alloys in 
$\mathrm{NaCl}$ solution-A powerful strategy for superior hydrogen generation performance. Int. J. Energy Res. 43(14), 84268438 (2019). https://doi.org/10.1002/er.4840

126. X. Hou, H. Shi, L. Yang, L. Feng, G. Suo et al., Comparative investigation on feasible hydrolysis $\mathrm{H}_{2}$ production behavior of commercial $\mathrm{Mg}-\mathrm{M}(\mathrm{M}=\mathrm{Ni}, \mathrm{Ce}$, and La) binary alloys modified by high-energy ball milling-Feasible modification strategy for Mg-based hydrogen producing alloys. Int. J. Energy Res. 44(14), 11956-11972 (2020). https://doi.org/10.1002/er.5843

127. K. Hou, X. Ye, X. Hou, Y. Wang, L. Yang et al., Rapid catalytic hydrolysis performance of $\mathrm{Mg}$ alloy enhanced by $\mathrm{MoS}_{2}$ auxiliary mass transfer. J. Mater. Sci. 56(7), 48104829 (2020). https://doi.org/10.1007/s10853-020-05552-z

128. Y. Nakagawa, C.-H. Lee, K. Matsui, K. Kousaka, S. Isobe et al., Doping effect of $\mathrm{Nb}$ species on hydrogen desorption properties of $\mathrm{AlH}_{3}$. J. Alloy Compd. 734, 55-59 (2018). https://doi.org/10.1016/j.jallcom.2017.10.273

129. Q.F. Li, N.J. Bjerrum, Aluminum as anode for energy storage and conversion: a review. J. Power Sources 110(1), 1-10 (2002). https://doi.org/10.1016/S0378-7753(01) 01014-X

130. J.S. Bryan, F.B. Krasne, Presynaptic inhibition: the mechanism of protection from habituation of the crayfish lateral giant fibre escape response. J. Physiol. 271(2), 369-390 (1977). https://doi.org/10.1113/jphysiol.1977.sp012005

131. K. Uehara, H. Takeshita, H. Kotaka, Hydrogen gas generation in the wet cutting of aluminum and its alloys. J. Mater. Process Tech. 127(2), 174-177 (2002). https://doi.org/10. 1016/S0924-0136(02)00121-8

132. Z.Y. Deng, J.M.F. Ferreira, Y. Sakka, Hydrogen-generation materials for portable applications. J. Am. Ceram. Soc. 91(12), 3825-3834 (2008). https://doi.org/10.1111/j. 1551-2916.2008.02800.x

133. H.Z. Wang, D.Y.C. Leung, M.K.H. Leung, M. Ni, A review on hydrogen production using aluminum and aluminum alloys. Renew. Sust. Energ. Rev. 13(4), 845-853 (2009). https://doi.org/10.1016/j.rser.2008.02.009

134. H.B. Dai, G.L. Ma, H.J. Xia, P. Wang, Reaction of aluminium with alkaline sodium stannate solution as a controlled source of hydrogen. Energy Environ. Sci. 4(6), 2206-2212 (2011). https://doi.org/10.1039/c1ee00014d

135. G.-L. Ma, H.-B. Dai, D.-W. Zhuang, H.-J. Xia, P. Wang, Controlled hydrogen generation by reaction of aluminum/ sodium hydroxide/sodium stannate solid mixture with water. Int. J. Hydrog. Energy 37(7), 5811-5816 (2012). https://doi.org/10.1016/j.ijhydene.2011.12.157

136. F. Habashi, A short history of hydrometallurgy. Hydrometallurgy 79(1-2), 15-22 (2005). https://doi.org/10.1016/j. hydromet.2004.01.008

137. J.P. Murray, Aluminum production using high-temperature solar process heat. Sol. Energy 66(2), 133-142 (1999). https://doi.org/10.1016/S0038-092X(99)00011-0

138. M.Q. Fan, F. Xu, L.X. Sun, Studies on hydrogen generation characteristics of hydrolysis of the ball milling Al-based materials in pure water. Int. J. Hydrog. Energy 32(14),
2809-2815 (2007). https://doi.org/10.1016/j.ijhydene.2006. 12.020

139. M.Q. Fan, L.X. Sun, F. Xu, Hydrogen production for microfuel-cell from activated Al-Sn-Zn-X (X: hydride or halide) mixture in water. Renew. Energy 36(2), 519-524 (2011). https://doi.org/10.1016/j.renene.2010.07.006

140. Y.A. Liu, X.H. Wang, H.Z. Liu, Z.H. Dong, S.Q. Li et al., Effect of salts addition on the hydrogen generation of AlLiH composite elaborated by ball milling. Energy 89, 907913 (2015). https://doi.org/10.1016/j.energy.2015.06.043

141. Y.Y. Jia, J. Shen, H.X. Meng, Y.M. Dong, Y.J. Chai et al., Hydrogen generation using a ball-milled $\mathrm{Al} / \mathrm{Ni} / \mathrm{NaCl}$ mixture. J. Alloy Compd. 588, 259-264 (2014). https://doi.org/ 10.1016/j.jallcom.2013.11.058

142. M.Q. Fan, F. Xu, L.X. Sun, Hydrogen generation by hydrolysis reaction of ball-milled Al-Bi alloys. Energy Fuel 21(4), 2294-2298 (2007). https://doi.org/10.1021/ef0700127

143. X.N. Huang, C.J. Lv, Y.X. Huang, S. Liu, C. Wang et al., Effects of amalgam on hydrogen generation by hydrolysis of aluminum with water. Int. J. Hydrog. Energy 36(23), 1511915124 (2011). https://doi.org/10.1016/j.ijhydene.2011.08.073

144. O.V. Kravchenko, K.N. Semenenko, B.M. Bulychev, K.B. Kalmykov, Activation of aluminum metal and its reaction with water. J. Alloy Compd. 397(1-2), 58-62 (2005). https:// doi.org/10.1016/j.jallcom.2004.11.065

145. A.V. Parmuzina, O.V. Kravchenko, Activation of aluminium metal to evolve hydrogen from water. Int. J. Hydrog. Energy 33(12), 3073-3076 (2008). https://doi.org/10.1016/j.ijhydene. 2008.02.025

146. M.Q. Fan, L.X. Sun, F. Xu, Feasibility study of hydrogen production for micro fuel cell from activated Al-In mixture in water. Energy 35(3), 1333-1337 (2010). https://doi.org/10. 1016/j.energy.2009.11.016

147. M.J. Baniamerian, S.E. Moradi, Al-Ga doped nanostructured carbon as a novel material for hydrogen production in water. J. Alloy Compd. 509(21), 6307-6310 (2011). https://doi.org/ 10.1016/j.jallcom.2011.03.069

148. J.T. Ziebarth, J.M. Woodall, R.A. Kramer, G. Choi, Liquid phase-enabled reaction of Al-Ga and Al-Ga-In-Sn alloys with water. Int. J. Hydrog. Energy 36(9), 5271-5279 (2011). https://doi.org/10.1016/j.ijhydene.2011.01.127

149. W. Wang, D.M. Chen, K. Yang, Investigation on microstructure and hydrogen generation performance of Al-rich alloys. Int. J. Hydrog. Energy 35(21), 12011-12019 (2010). https:// doi.org/10.1016/j.ijhydene.2010.08.089

150. T.P. Huang, Q. Gao, D. Liu, S.N. Xu, C.B. Guo et al., Preparation of Al-Ga-In-Sn-Bi quinary alloy and its hydrogen production via water splitting. Int. J. Hydrog. Energy 40(5), 2354-2362 (2015). https://doi.org/10.1016/j.ijhydene.2014. 12.034

151. H.S. Nam, D.J. Srolovitz, Effect of material properties on liquid metal embrittlement in the Al-Ga system. Acta Mater. 57(5), 1546-1553 (2009). https://doi.org/10.1016/j.actamat. 2008.11 .041 
152. W. Wang, W. Chen, X.M. Zhao, D.M. Chen, K. Yang, Effect of composition on the reactivity of Al-rich alloys with water. Int. J. Hydrog. Energy 37(24), 18672-18678 (2012). https:// doi.org/10.1016/j.ijhydene.2012.09.164

153. S.-C. Tan, H. Gui, X.-H. Yang, B. Yuan, S.-H. Zhan et al., Comparative study on activation of aluminum with four liquid metals to generate hydrogen in alkaline solution. Int. J. Hydrog. Energy 41(48), 22663-22667 (2016). https://doi.org/ 10.1016/j.ijhydene.2016.10.090

154. H.H. Wang, Y. Chang, S.J. Dong, Z.F. Lei, Q.B. Zhu et al., Investigation on hydrogen production using multicomponent aluminum alloys at mild conditions and its mechanism. Int. J. Hydrog. Energy 38(3), 1236-1243 (2013). https:// doi.org/10.1016/j.ijhydene.2012.11.034

155. D.X. Qiao, Y.P. Lu, Z.Y. Tang, X.S. Fan, T.M. Wang et al., The superior hydrogen-generation performance of multicomponent Al alloys by the hydrolysis reaction. Int. J. Hydrog. Energy 44(7), 3527-3537 (2019). https://doi.org/ 10.1016/j.ijhydene.2018.12.124

156. W. Yang, T. Zhang, J. Zhou, W. Shi, J. Liu et al., Experimental study on the effect of low melting point metal additives on hydrogen production in the aluminum-water reaction. Energy 88, 537-543 (2015). https://doi.org/10.1016/j. energy.2015.05.069

157. Y. Liu, X. Wang, H. Liu, Z. Dong, S. Li et al., Effect of salts addition on the hydrogen generation of $\mathrm{Al}-\mathrm{LiH}$ composite elaborated by ball milling. Energy 89, 907-913 (2015). https://doi.org/10.1016/j.energy.2015.06.043

158. Y. Jia, J. Shen, H. Meng, Y. Dong, Y. Chai et al., Hydrogen generation using a ball-milled $\mathrm{Al} / \mathrm{Ni} / \mathrm{NaCl}$ mixture. J. Alloy. Compd. 588, 259-264 (2014). https://doi.org/10. 1016/j.jallcom.2013.11.058

159. M.-Q. Fan, F. Xu, L.-X. Sun, Hydrogen generation by hydrolysis reaction of ball-milled Al-Bi alloys. Energy Fuels 21(4), 2294-2298 (2007). https://doi.org/10.1021/ ef0700127

160. M.-Q. Fan, L.-X. Sun, F. Xu, Feasibility study of hydrogen production for micro fuel cell from activated Al-In mixture in water. Energy 35(3), 1333-1337 (2010). https://doi.org/10. 1016/j.energy.2009.11.016

161. M.J. Baniamerian, S.E. Moradi, Al-Ga doped nanostructured carbon as a novel material for hydrogen production in water. J. Alloy. Compd. 509(21), 6307-6310 (2011). https://doi.org/ 10.1016/j.jallcom.2011.03.069

162. J.T. Ziebarth, J.M. Woodall, R.A. Kramer, G. Choi, Liquid phase-enabled reaction of Al-Ga and Al-Ga-In-Sn alloys with water. Int. J. Hydrog. Energy 36(9), 5271-5279 (2011). https://doi.org/10.1016/j.ijhydene.2011.01.127

163. C. Wang, C. Qiu, H. Wei, H. Zou, K. Lin et al., Mild hydrogen production from the hydrolysis of $\mathrm{Al}-\mathrm{Bi}-\mathrm{Zn}$ composite powder. Int. J. Hydrog. Energy 46(14), 9314-9323 (2021). https://doi.org/10.1016/j.ijhydene.2020.12.104

164. M. Su, H. Hu, J. Gan, W. Ye, W. Zhang et al., Thermodynamics, kinetics and reaction mechanism of hydrogen production from a novel $\mathrm{Al}$ alloy/ $\mathrm{NaCl} / \mathrm{g}-\mathrm{C}_{3} \mathrm{~N}_{4}$ composite by low temperature hydrolysis. Energy 218, 119489 (2021). https:// doi.org/10.1016/j.energy.2020.119489

165. S. Liu, M.Q. Fan, D. Chen, C.J. Lv, The effect of composition design on the hydrolysis reaction of $\mathrm{Al}-\mathrm{Li}-\mathrm{Sn}$ alloy and water. Energy Sour. Part A: Recov. Util. Environ. Eff. 37(4), 356-364 (2015). https://doi.org/10.1080/15567036. 2011.580325

166. Y. Liu, X. Liu, X. Chen, S. Yang, C. Wang, Hydrogen generation from hydrolysis of activated Al-Bi, Al-Sn powders prepared by gas atomization method. Int. J. Hydrog. Energy 42(16), 10943-10951 (2017). https://doi.org/10.1016/j.ijhyd ene.2017.02.205

167. S.P. du Preez, D.G. Bessarabov, Hydrogen generation of mechanochemically activated Al Bi In composites. Int. J. Hydrog. Energy 42(26), 16589-16602 (2017). https://doi. org/10.1016/j.ijhydene.2017.05.211

168. B.D. Du, W. Wang, W. Chen, D.M. Chen, K. Yang, Grain refinement and Al-water reactivity of $\mathrm{Al} \mathrm{Ga} \mathrm{In} \mathrm{Sn} \mathrm{alloys.} \mathrm{Int.}$ J. Hydrog. Energy 42(34), 21586-21596 (2017). https://doi. org/10.1016/j.ijhydene.2017.07.105

169. F. Zhang, K. Edalati, M. Arita, Z. Horita, Fast hydrolysis and hydrogen generation on $\mathrm{Al}-\mathrm{Bi}$ alloys and $\mathrm{Al}-\mathrm{Bi}-\mathrm{C}$ composites synthesized by high-pressure torsion. Int. J. Hydrog. Energy 42(49), 29121-29130 (2017). https://doi.org/10.1016/j.ijhyd ene.2017.10.057

170. F. Xu, X. Zhang, L. Sun, F. Yu, P. Li et al., Hydrogen generation of a novel $\mathrm{Al} \mathrm{NaMgH}$ composite reaction with water. Int. J. Hydrog. Energy 42(52), 30535-30542 (2017). https:// doi.org/10.1016/j.ijhydene.2017.10.161

171. C. Zhao, F. Xu, L. Sun, J. Chen, X. Guo et al., A novel Al $\mathrm{BiOCl}$ composite for hydrogen generation from water. Int. J. Hydrog. Energy 44(13), 6655-6662 (2019). https://doi.org/ 10.1016/j.ijhydene.2018.12.165

172. Z. Liu, H. Zhao, L. Han, W. Cui, L. Zhou et al., Improvement of the acid resistance, catalytic efficiency, and thermostability of nattokinase by multisite-directed mutagenesis. Biotechnol. Bioeng. 116(8), 1833-1843 (2019). https://doi.org/10.1002/ bit. 26983

173. X. Guan, Z. Zhou, P. Luo, F. Wu, S. Dong, Hydrogen generation from the reaction of Al-based composites activated by low-melting-point metals/oxides/salts with water. Energy 188, 116107 (2019). https://doi.org/10.1016/j.energy.2019. 116107

174. D. Liu, Q. Gao, Q. An, H. Wang, J. Wei et al., Experimental study on Zn-doped Al-rich alloys for fast on-board hydrogen production. Curr. Comput.-Aided Drug Des. 10(3), 167 (2020). https://doi.org/10.3390/cryst10030167

175. T. He, W. Chen, W. Wang, F. Ren, H.-R. Stock, Effect of different $\mathrm{Cu}$ contents on the microstructure and hydrogen production of $\mathrm{Al}-\mathrm{Cu}-\mathrm{Ga}-\mathrm{In}-\mathrm{Sn}$ alloys for dissolvable materials. J. Alloy. Compd. 821, 153489 (2020). https://doi.org/ 10.1016/j.jallcom.2019.153489

176. T. He, W. Chen, W. Wang, S. Du, S. Deng, Microstructure and hydrogen production of the rapidly solidified Al-Mg-GaIn-Sn alloy. J. Alloy. Compd. 827, 154290 (2020). https://doi. org/10.1016/j.jallcom.2020.154290 
177. K. Naseem, H. Zhong, H. Wang, L. Ouyang, M. Zhu, Promoting $\mathrm{Al}$ hydrolysis via $\mathrm{MgH}_{2}$ and $\mathrm{NaOH}$ addition. J. Alloy. Compd. 831, 154793 (2020). https://doi.org/10.1016/j.jallc om.2020.154793

178. S. Prabu, H.-W. Wang, Enhanced hydrogen generation from graphite-mixed aluminum hydroxides catalyzed Al/water reaction. Int. J. Hydrog. Energy 45(58), 33419-33429 (2020). https://doi.org/10.1016/j.ijhydene.2020.09.036

179. J. Guo, Z. Su, J. Tian, J. Deng, T. Fu et al., Enhanced hydrogen generation from Al-water reaction mediated by metal salts. Int. J. Hydrog. Energy 46(5), 3453-3463 (2021). https:// doi.org/10.1016/j.ijhydene.2020.10.220

180. H. Zhong, H. Wang, J.W. Liu, D.L. Sun, F. Fang et al., Enhanced hydrolysis properties and energy efficiency of $\mathrm{MgH}_{2}$-base hydrides. J. Alloy. Compd. 680, 419-426 (2016). https://doi.org/10.1016/j.jallcom.2016.04.148

181. R. Xiao, J. Chen, K. Fu, X. Zheng, T. Wang et al., Hydrolysis batteries: generating electrical energy during hydrogen absorption. Angew. Chem. Int. Ed. 57(8), 2219-2223 (2018). https://doi.org/10.1002/anie.201711666

182. L. Ouyang, W. Chen, J. Liu, M. Felderhoff, H. Wang et al., Enhancing the regeneration process of consumed $\mathrm{NaBH}_{4}$ for hydrogen storage. Adv. Energy Mater. 7(19), 1700299 (2017). https://doi.org/10.1002/aenm.201700299

183. H. Zhong, L.Z. Ouyang, J.S. Ye, J.W. Liu, H. Wang et al., An one-step approach towards hydrogen production and storage through regeneration of $\mathrm{NaBH}_{4}$. Energy Storage Mater. 7, 222-228 (2017). https://doi.org/10.1016/j.ensm.2017.03.001

184. H.I. Schlesinger, H.C. Brown, B. Abraham, A. Bond, N. Davidson et al., New developments in the chemistry of diborane and the borohydrides. I. General Summary. J. Am. Chem. Soc. 75(1), 186-190 (1953). https://doi.org/10.1021/ ja01097a049

185. S. Friedrich, L. Konrad, Production of Alkali Metal Borohydrides. Google Patents: 1965.

186. Z.P. Li, N. Morigazaki, B.H. Liu, S. Suda, Preparation of sodium borohydride by the reaction of $\mathrm{MgH}_{2}$ with dehydrated borax through ball milling at room temperature. J. Alloy. Compd. 349(1-2), 232-236 (2003). https://doi.org/10.1016/ S0925-8388(02)00872-1

187. Ç. Çakanyildirim, M. Gürü, The production of $\mathrm{NaBH}_{4}$ from its elements by mechano-chemical reaction and usage in hydrogen recycle. Energy Sour. Part A: Recov. Util. Environ. Eff. 33(20), 1912-1920 (2011). https://doi.org/10.1080/ 15567030903503175

188. M. Bilen, M. Gürü, Ç. Çakanyıldırım, Role of $\mathrm{NaCl}$ in $\mathrm{NaBH}_{4}$ production and its hydrolysis. Energy Convers. Manag. 72, 134-140 (2013). https://doi.org/10.1016/j.enconman.2012. 08.031

189. S. Garroni, C.B. Minella, D. Pottmaier, C. Pistidda, C. Milanese et al., Mechanochemical synthesis of $\mathrm{NaBH}_{4}$ starting from $\mathrm{NaH}-\mathrm{MgB}_{2}$ reactive hydride composite system. Int. J. Hydrog. Energy 38(5), 2363-2369 (2013). https://doi.org/10. 1016/j.ijhydene.2012.11.136
190. Y. Kojima, T. Haga, Recycling process of sodium metaborate to sodium borohydride. Int. J. Hydrog. Energy 28(9), 989-993 (2003). https://doi.org/10.1016/S0360-3199(02) 00173-8

191. C.-L. Hsueh, C.-H. Liu, B.-H. Chen, C.-Y. Chen, Y.-C. Kuo et al., Regeneration of spent- $\mathrm{NaBH}_{4}$ back to $\mathrm{NaBH}_{4}$ by using high-energy ball milling. Int. J. Hydrog. Energy 34(4), 17171725 (2009). https://doi.org/10.1016/j.ijhydene.2008.12.036

192. L. Kong, X. Cui, H. Jin, J. Wu, H. Du et al., Mechanochemical synthesis of sodium borohydride by recycling sodium metaborate. Energy Fuel 23(10), 5049-5054 (2009). https:// doi.org/10.1021/ef900619y

193. Ç. Çakanyıldırım, M. Gürü, Processing of $\mathrm{NaBH}_{4}$ from $\mathrm{NaBO}_{2}$ with $\mathrm{MgH}_{2}$ by ball milling and usage as hydrogen carrier. Renew. Energy 35(9), 1895-1899 (2010). https://doi. org/10.1016/j.renene.2010.01.001

194. M. Felderhoff, L. Ouyang, M. Zhu, H.Z. Zhong, H. Shao et al., Realizing Facile Regeneration of spent $\mathrm{NaBH}_{4}$ with Mg-Al Alloy. J. Mater. Chem. A 7, 10723-10728 (2019). https://doi.org/10.1039/c9ta00769e

195. W. Chen, L.Z. Ouyang, J.W. Liu, X.D. Yao, H. Wang et al., Hydrolysis and regeneration of sodium borohydride ( $\mathrm{NaBH} 4)$ - A combination of hydrogen production and storage. J. Power Sources 359, 400-407 (2017). https://doi.org/10. 1016/j.jpowsour.2017.05.075

196. Y.Y. Zhu, L.Z. Ouyang, H. Zhong, J.W. Liu, H. Wang et al., Closing the loop for hydrogen storage: facile regeneration of $\mathrm{NaBH}_{4}$ from its hydrolytic product. Angew. Chem. Int. Ed. 59(22), 8623-8629 (2020). https://doi.org/10.1002/anie. 201915988

197. Y. Zhu, L. Ouyang, H. Zhong, J. Liu, H. Wang et al., Efficient synthesis of sodium borohydride: balancing reducing agents with intrinsic hydrogen source in hydrated borax. ACS Sustain. Chem. Eng. 8(35), 13449-13458 (2020). https://doi.org/ 10.1021/acssuschemeng.0c04354

198. L. Ouyang, H. Zhong, H.-W. Li, M. Zhu, A recycling hydrogen supply system of $\mathrm{NaBH}_{4}$ based on a facile regeneration process: A review. Inorganics 6(1), 10 (2018). https://doi.org/ 10.3390/inorganics6010010

199. M. Bilen, O. Yilmaz, M. Guru, Synthesis of LiBH4 from $\mathrm{LiBO}_{2}$ as hydrogen carrier and its catalytic dehydrogenation. Int. J. Hydrog. Energy 40(44), 15213-15217 (2015). https:// doi.org/10.1016/j.ijhydene.2015.02.085

200. M. Touboul, E. Bétourné, Dehydration process of lithium borates. Solid State Ion. 84(3), 189-197 (1996). https://doi. org/10.1016/0167-2738(96)00027-6

201. K. Chen, L. Ouyang, H. Zhong, J. Liu, H. Wang et al., Converting $\mathrm{H}+$ from coordinated water into $\mathrm{H}$ - enables super facile synthesis of $\mathrm{LiBH}_{4}$. Green Chem. 21(16), 4380-4387 (2019). https://doi.org/10.1039/C9GC01897B

202. M. Bilen, M. Gürü, Ç. Çakanyildirim, Conversion of $\mathrm{KCl}$ into $\mathrm{KBH}_{4}$ by mechano-chemical reaction and its catalytic decomposition. J. Electron. Mater. 46(7), 4126-4132 (2017). https://doi.org/10.1007/s11664-017-5340-0 